\title{
Aspects of local host defence, nosocomial pneumonia and viral reactivation in ventilated intensive care patients
}

\author{
Citation for published version (APA):
}

Dennesen, P. J. W. (2003). Aspects of local host defence, nosocomial pneumonia and viral reactivation in ventilated intensive care patients. [Doctoral Thesis, Maastricht University]. Universiteit Maastricht. https://doi.org/10.26481/dis.20030124pd

Document status and date:

Published: 01/01/2003

DOI:

10.26481/dis.20030124pd

Document Version:

Publisher's PDF, also known as Version of record

\section{Please check the document version of this publication:}

- A submitted manuscript is the version of the article upon submission and before peer-review. There can be important differences between the submitted version and the official published version of record. People interested in the research are advised to contact the author for the final version of the publication, or visit the DOI to the publisher's website.

- The final author version and the galley proof are versions of the publication after peer review.

- The final published version features the final layout of the paper including the volume, issue and page numbers.

Link to publication

\footnotetext{
General rights rights.

- You may freely distribute the URL identifying the publication in the public portal. please follow below link for the End User Agreement:

www.umlib.nl/taverne-license

Take down policy

If you believe that this document breaches copyright please contact us at:

repository@maastrichtuniversity.nl

providing details and we will investigate your claim.
}

Copyright and moral rights for the publications made accessible in the public portal are retained by the authors and/or other copyright owners and it is a condition of accessing publications that users recognise and abide by the legal requirements associated with these

- Users may download and print one copy of any publication from the public portal for the purpose of private study or research.

- You may not further distribute the material or use it for any profit-making activity or commercial gain

If the publication is distributed under the terms of Article $25 \mathrm{fa}$ of the Dutch Copyright Act, indicated by the "Taverne" license above, 
Aspects of local host defence, nosocomial pneumonia and viral reactivation in ventilated intensive care patients 
(C) P.J.W. Dennesen, Maastricht 2003

ISBN 90-9016588-6

Cover illustrations by Karin Schröder

Printed by Pasmans Offsetdrukkerij bv, The Hague 


\title{
Aspects of local host defence, nosocomial pneumonia and viral reactivation in ventilated intensive care patients
}

\author{
PROEFSCHRIFT \\ ter verkrijging van de graad van doctor \\ aan de Universiteit Maastricht, \\ op het gezag van de Rector Magnificus, \\ Prof. Dr. A.C. Nieuwenhuijzen Kruseman, \\ volgens het besluit van het college van Decanen, \\ in het openbaar te verdedigen \\ op vrijdag 24 januari 2003 om 12.00 uur
}

door

Paul Johannes Wilhelmus Dennesen Geboren op 10 juli 1960 te Nijmegen 


\section{Promotores}

Prof. dr. C.A. Bruggeman

Prof. dr. G. Ramsay

\section{Co-promotor:}

Dr. A.J.A.M. van der Ven

\section{Beoordelingscommissie}

Prof. dr. P.B. Soeters

Dr. M.J.M. Bonten

Prof. dr. H.F.P. Hillen

Dr. J.G. van der Hoeven

Prof. dr. L.G. Thijs

Prof. dr. E.F.M. Wouters

Additional financial support for publication of this thesis was generously provided by Pharmacia N.V. and Roche Nederland N.V. 
Voor mijn ouders, Carla, en mijn dochters 


\section{Contents}

Introduction and outtine of the study

Inadequate salivary flow and poor oral mucosal status in intubated ICU patients

Paul J.W. Dennesen, André J.A.M. van der Ven, Mariel Vlasveld, Linka Lokker, Graham Ramsay, Alphons G.H. Kessels, Petra van den Keijbus, Arie van Nieuw Amerongen, Enno C.I. Veerman.

Accepted for publication in Crit Care Medicine

2 Resolution of infectious parameters after antimicrobial therapy in patients with ventilator-associated pneumonia

Paul J.W. Dennesen, André J.A.M. van der Ven, Alphons G.H. Kessels, Graham Ramsay, Mare J.M. Bonten.

Am J Respir Crit Care Med 2001; 163: 1371-1375

3 High levels of sulfated mucins in bronchoalveolar lavage fluid of ICU patients with ventilator-associated pneumonia

Paul J.W. Dennesen, Enno C.I. Veerman, Arie van Nieuw Amerongen, Jan A. Jacobs, Alphons G.H. Kessels, Petra van der Keybus, Graham Ramsay, André J.A.M. van der Ven.

Submitted

4 Non-specific Cytoplasmic Cytomegalovirus Antigen detection after Coronary Bypass Surgery

Paul J.W. Dennesen, André J.A.M. van der Ven, Marinus J. Blok, Jos G. Maessen, Alphons G.H. Kessels, Graham Ramsay, Cathrien A. Bruggeman. Eur J Clin Microbiol Infect Dis 2001; 20: 681-683 
5 Reactivation of human cytomegalovirus and herpes simplex virus frequently occurs in non-immune compromised patients admitted to the intensive care

Paul J.W. Dennesen, Cathrien A. Bruggeman, Hubert G.M. Niesters, Marinus J. Blok, Jan A. Jacobs, Graham Ramsay, André J.A.M. van der Ven.

Submitted

6 summary

Samenvatting

List of abbreviations

Dankwoord

Curriculum vitae

103 


\section{Introduction and outline of the study}


Patients are admitted to the intensive care unit (ICU) when vital body functions are threatened and action has to be taken to prevent, reverse or minimize damage to organs like the brain, kidney and gut. In case of cardiovascular and respiratory failure, inotropes and mechanical ventilation are applied to improve the oxygenation of the tissues. Despite these corrective measures, a further derailment of vital body functions may occur with multiple organ failure as a result. One of the vital body functions that may be compromised is the host defence, making the patient vulnerable for developing nosocomial infections.

The intact skin and mucous membranes, as part of the non-specific host defence, are important barriers for potentially pathogenic microorganisms (ppmo) like Staphylococcus aureus, Enterobacteriaceae and Pseudomonas aeruginosa. These structures prevent the invasion of microorganisms not only in a mechanical way but also by limiting the adherence of ppmo's. In healthy subjects, the oral cavity is colonized by a myriad of large numbers of aerobic Gram-positive as well as anaerobic bacteria (1). In critically ill patients, however, Gram-negative bacteria (GNB) often colonize the oral mucosal cavity (2). If ventilated, colonization of the oral cavity with GNB occurs within 48-72 hours of admission to the critical care area (3). Because of micro-aspiration, the trachea and even the lung may also become colonized with ppmo's and a nosocomial pneumonia may subsequently develop (4). Especially mechanically ventilated patients are at risk of developing nosocomial pneumonia, a so-called ventilator-associated pneumonia (VAP) (5), the most prevalent nosocomial infection in the ICU (6).

In healthy subjects saliva plays a key role in maintaining the intactness of the oral mucous membranes and the health of the oral cavity through its antimicrobial, lubricating, and buffering properties $(7,8)$. In relation to the oral flora, saliva is capable of regulating the composition of this flora by means of its antimicrobial activity creating a selective microbial clearance or adherence. Several components of saliva contribute to this antimicrobial activity, i.e. lysozyme, lactoferrin, peroxidases, fibronectin, histatins, cystatins, proline-rich glycoproteins, slgA and mucins (9). Patients admitted to the intensive care either in an emergency or following elective surgery often require oral intubation to facilitate mechanical ventilation. It is generally accepted that these patients suffer from dryness of the mouth due to a lack of normal salivary secretions (xerostomia).

Several drugs, used routinely in the ICU, can contribute to xerostomia (10). Also intubated patients are forced to keep their mouths open at all times leading to dryness of the mucosa (11). It is also common practice in intensive care units to keep patients deliberately "dehydrated" in order to improve respiratory and cardiac 
function. In time xerostomia will lead to mucosal damage and subsequently mucositis. These changes to the oral mucosa in intubated ICU patients may increase bacterial adherence to the epithelial cells in the oral cavity, thus making colonization and proliferation much more probable (12). A limited number of studies $(13,14,15)$ have examined the extent of mucositis and salivary flow in relation to oropharyngeal colonization. These studies included patients with the Sjogren syndrome and irradiated head and neck cancer patients, never ICU patients.

A prospective study was therefore conducted to investigate salivary characteristics, incidence of oral mucositis, and oropharyngeal colonization in ICU patients and compared the results with peri-operative observations in patients admitted for elective coronary by-pass surgery (chapter 1). The latter patients experience a serious but relatively short lasting injury while the ICU patients were critically ill during a much longer period of time.

Of all antibiotics prescribed for therapy in ICU patients, approximately $50 \%$ are administered for respiratory tract infections, especially VAP (16). The overuse of antibiotics creates a constant threat for selection and induction of multi-resistant pathogens, a nightmare for every ICU. One of the methods to achieve a reduction of antibiotic use is to shorten the duration of therapy for respiratory tract infections. The appropriate duration of antibiotic therapy for VAP is however questionable. The course of infectious parameters in patients appropriately treated for VAP, could be utilized, among others, to draw up guidelines. Although guidelines have been issued by the American Thoracic Society (ATS) on the duration of antibiotic therapy for VAP (17), these recommendations are not based on the results of prospective studies regarding the resolution of infectious parameters. In general, there is sparse information about the resolution of infectious parameters associated with VAP after institution of appropriate antibiotic therapy: chapter $\mathbf{2}$ describes such a prospective study.

The etiologic spectrum of VAP over time resembles that of cystic fibrosis (CF); in the first days after the start of mechanical ventilation VAP is mainly caused by Gram-positive micro-organisms ( $S$. aureus) while later on a shift in etiology takes place toward GNB, especially $P$. aeruginosa $(18,19)$. Despite appropriate antibiotic therapy for VAP caused by GNB, there is persistence in colonization with GNB of the lower airways, whereas Gram-positive microorganisms are easily eradicated. Why this difference in colonization? One of the explanations could be an alteration in airway mucins composition. These mucins, which are a major component of the mucus layer, play an important role in the innate immunity of the lower airways, 
protecting the respiratory mucosa from ppmo invasion (20). Alteration of the composition of airway mucins could be favourable for the persistence of GNB. Indeed in CF patients suffering from persistent GNB colonization, increased levels of sulfation and sialylation of mucins in sputum have been reported (21). Therefore we performed a prospective study comparing the levels of sulfated mucins in bronchoalveolar lavage fluid in ventilated ICU patients with and without VAP with nonventilated subjects (chapter $\mathbf{3}$ ).

Alterations of host defence in ICU patients do not only occur at the level of intactness of (mechanical) barriers, but other components of the non-specific and specific immunity, may be compromised as well (22). Impaired cellular immunity may result in reactivation of latent viral infections. Herpes viruses such as Herpes simplex virus type 1 (HSV-1) and Cytomegalovirus (CMV) have the ability to establish a lifelong latent infection after primary infection. Reactivation can lead to a serious systemic disease mostly occurring however in case of severe immunosuppression. On the other hand, asymptomatic shedding or incomplete reactivation has been documented, also in apparently immunocompetent individuals (23). During reactivation, these viruses are able to cause mucosal damage of the upper en lower airways. HSV-1 can cause gingivo-stomatitis, and even tracheobronchitis, which has been described in intensive care patients (24). CMV can cause xerostomia (25) and even pneumonia (26). Interestingly CMV influences the degree of oropharyngeal colonization with GNB, as was shown in renal transplant (27). Apart from a possible effect on the upper or lower respiratory mucous membranes, these viruses can also infect circulating monocytes and endothelial cells with enhanced coagulation as a result $(28,29)$. Moreover, reactivation of CMV may further compromise patient's host defences (30).

Indeed, there have been reports on the reactivation of Herpes viruses in the ICU setting. Especially in surgical, trauma, and burn patients $(31,31,33)$. Herpes virus involvement has also been documented in ARDS (34). These studies have their limitations because the groups patients were highly selected. Furthermore these studies were retrospective, and a very limited number of samples were taken and or a limited number of laboratory techniques were applied. Until recently, a CMV infection was assessed by a fourfold rise in serological titer or by demonstrating a cytopathological effect in cell cultures. These techniques were used in some of the above-referenced studies. Nowadays, more sophisticated and sensitive methods, like CMV antigenemia, Polymerase chain reaction (PCR) and nucleic acid sequence-based amplificapion (NASBA), are at our disposal for the detection of CMV $(35,36)$. The results regarding CMV detection by means of these techniques in ICU 
patients are conflicting. In contrast to Stephan et al, who found no CMV reactivation in blood and BAL samples in mechanical ventilated ICU patients (37), Kutza et al. reported a high incidence of active CMV infection in blood samples of septic ICU patients (38).

Therefore two prospective studies, investigating the incidence of reactivation of CMV and HSV-1, were carried out. In these surveying studies, oral swabs, urine, blood samples were collected at regular intervals in a unselected group of ICU patients and were analysed for the presence of these viruses by means of culture and molecular biological methods. One study (Chapter 4) was performed in patients undergoing elective coronary bypass surgery. The burden of hemodynamic instability, mechanical ventilation, starvation, medication and other possible factors that may modulate host defence is of relatively short duration. In addition, patients can be studied before the intervention. The second study (Chapter 5) was performed in patients admitted to the intensive care because of the need for mechanical ventilation, with an expected duration of ICU stay of at least 7 days. Compared to coronary bypass surgery patients, these patients are more seriously ill over a longer period of time and the incidence, the duration and systemic distribution of the viral reactivation may therefore be enhanced. Additionally, all bronchoalveolar fluid samples of these patients obtained as part of the diagnostic workup of VAP were tested for the presence of HSV and CMV.

\section{References}

1. Machowiak PA. The normal microbial flora. N Engl J Med 1982; 307:83-86.

2. Johanson WG, Pierce AK, Sanford JP. Changing pharyngeal bacterial flora of hospitalized patients. Emergence of gram-negative bacilli. N Engl J Med 1969; 28:1137-1140.

3. Johanson WG. Prevention of respiratory tract infection. Am J Med 1984; 76(suppl 5a): 69-77.

4. Estes RJ, Meduri GU. The pathogenesis of ventilator-associated pneumonia: I. Mechanisms of bacterial transcolonization and airway inoculation. Intensiv Care Med $1995 ; 21: 365-383$.

5. Torres A, Aznar R, Gatell JM, Jimenez P, Gonzalez J, Ferrer A, Celis R, Rodriguez-Roisin $R$. Incidence, risk, and prognosis factors of nosocomial pneumonia in mechanically ventilated patients. Am Rev Respir Dis 1990; 142:523-528.

6. Vincent JL, Bihari DJ, Suter PM, Bruining HA, White J, Nicolas-Chanoin MH, Wolff M, Spencer RC. Hemmer M. The prevalence of nosocomial infection in intensive care units in Europe. Results of the european prevalence of infection in intensive care (EPIC) study. J Am Med Association 1995; 274:639-644. 
7. Hatton MN, Loomis RE, Levine MJ, Tabak LA. Masticatory lubrication. The role of carbohydrate in the lubricating property of a salivary glycoprotein-albumin complex. Biochem J 1985; 230:817-820.

8. Mandel ID. The functions of saliva. J Dent Res 1987; 66: 623-627.

9. Schenkels LCPM, Veerman ECI. Nieuw Amerongen AV. Biochemical composition of human saliva in relation to other mucosal fluids. Crit Rev Oral Biol Med 1995; 6:161-175.

10. Moore J. Assesment of nurse-administered oral hygiene. Nurs Times 1995; 91:40-41.

11. Jenkins DA. Oral care in the ICU: an important nursing role. Nurs Stand 1989; 4:24-29.

12. Johanson WG, Higuchi JH, Chauduri TR. Woods DE. Bacterial adherence to epithelial cells in bacillary colonization of the respiratory tract. Am Rev Respir Dis 1980; 121: 55-63.

13. Almstahl A, Kroneld U, Tarkowski A, Wikstrom M. Oral microbial flora in Sjögren's syndrome. J Rheumatol 1999; 26:110-114.

14. Spijkervet FK, van-Saene HK, Panders AK , Vermey A, van-Saene JJ, Mehta DM, Fidler $V$. Effect of chlorhexidine rinsing on the oropharyngeal ecology in patients with head and neck cancer who have irradiation mucositis. Oral Surg Oral Med Oral Pathol 1989; 67:154-161.

15. Martin MV, van-Saene HK. The role of oral microorganisms in cancer therapy. Curr Opin Dent 1992; $2: 81-84$.

16. Bergmans DCJJ, Bonten MJM, Gaillard CA, van Tiel FH, van der Geest S, de Leeuw PW, Stobberingh EE. Indications for antibiotic use in ICU patients: a one-year prospective surveillance. J Antimicrob Chemother 1997; 39:527-535.

17. Hospital-acquired pneumonia in adults: Diagnosis, Assessment of severity, Initial antimicrobial therapy, and Preventative Strategies. A consensus statement. Am J Respir Crit Care Med 1995; 153:1711-1725.

18. Armstrong, DS, Grimwood, K, Carzino, R, Carlin, JB, Olinsky, A, Phelan, PD. Lower respiratory infection and inflammation in infants with newly diagnosed cystic fibrosis. BMJ 1995; 310:1571-1572.

19. Craven DE, Steger KA. Ventilator-associated bacterial pneumonia: Challenges in diagnosis, treatment, and prevention. New Horiz 1998; 6:S31-45.

20. Lamblin G, Roussel P. Airway mucins and their role in defence against micro-organisms. Resp Med 1993; 87:421-426.

21. Chace, KV, Flux, M, Sachdev, GP. Comparison of physicochemical properties of purified mucus glycoproteins isolated from respiratory secretions of cystic fibrosis and asthmatic patients. Biochemistry 1985; 24:7334-7341.

22. Bradley JA, Hamilton DN, Brown MW, Cance W, Jackson VS, Ledingham IM. Cellular defense in critically ill surgical patients. Crit Care Med 1984; 12:565-570.

23. Zanghellini F, Boppana SB, Emery VC, Griffiths PD, Pass RF. Asymptomatic primairy cytomegalovirus infection: virologic and immunologic features. Clin Infect Dis 1999; 180:702-707.

24. Sherry MK, Klainer AS, Wolff M, Gerhard H. Herpetic tracheobronchitis. Ann Intern Med 1988; 109:229-233. 
25. Guntinas-Lichius O, Wagner M, Krueger GRF, Streppel M, Voessing M, Stennert E. Severe acute cytomegalovirus sialadenitis in an immunocompetent adult: case report. Clin Infect Dis 1996; 22:1117-1118.

26. Papazian L, Fraisse A, Garbe L, Zandotti C, Thomas P, Saux P, Pierrin G, Gouin F. Cytomegalovirus. An unexpected cause of ventilator-associated pneumonia. Anesthesiology 1996; 84:280-287.

27. Mackowiak PA, Goggans M, Torres W, Dal Nogare A, Luby JP, Helderman H. Relationship between cytomegolovirus and colonization of the oropharynx by gram. negative bacilli following renal transplantation. Epidemiol Infect 1991;107: 411-420.

28. Pryzdial LG, Wright JF. Prothrombinase assembly on an enveloped virus: Evidence that the cytomegalovirus surface contains procoagulant phospholipid. Blood 1994; 84:3749. 3757.

29. Sutherland MR, Raynor CM, Leenknegt H, Wright JF, Pryzdial. Coagulation initiated on herpesviruses. Proc Natl Acad Sci USA 1997; 94:13510-13514.

30. Nanicke D, Oldstone MB. Generalized immunosuppression: how viruses undermine the immune response. Cell Mol Life Sci 2000; 57:1399-407.

31. Cook CH, Yenchar JK, Kraner TO, Davies EA, Ferguson RM. Occult herpes family viruses may increase mortality in critically ill surgical patients. Am J Surg 1998; 176:357-360.

32. Cushing D, Elliot S, Caplan E, et al. Herpes simples virus and cytomegalovirus excretion associated with increased ventilator days in trauma patients. J Trauma 1993; 35:161.

33. Hayden FG, Himel HN, Heggers JP. Herpesvirus infections in burn patients. Chest 1994; 106: S15-S21.

34. Tuxen DV, Cade JF, McDonald MI, Buchanan MR, Clark RJ, Pain MC. Herpes simplex virus from the lower respiratory tract in adult respiratory distess syndrome. Am Rev Respir Dis 1982;126: 416-419.

35. Verschuuren EA, Harmsen MC, Limburg PC, van Der Bij W, van Den Berg AP, KasDeelen AM, Meedendorp B, van Son WJ, The TH. Towards standardization of the human cytomegalovirus antigenemia assay. Intervirology 1999; 42:382-9.

36. Hodinka RL. The clinical utility of viral quantitation using molecular methods. Clin Diagn Virol 1998; 10:25-47.

37. Stephan F, Meharzi D, Ricci S, Fajac A, Clergue F, Bernaudin JF. Evaluation by polymerase chain reaction of cytomegalovirus reactivation in intensive care patients under mechanical ventilation. Intensiv Care Med 1996; 22:1244-1249.

38. Kutza AS, Muhl E, Hackstein H, Kirchner H, Bein G. High incidence of cytomegalovirus infection among septic patients. Clin Infect Dis 1998; 26:1076-82. 


\section{Inadequate salivary flow and poor oral mucosal status in intubated ICU patients}

Paul J.W. Dennesen, André J.A.M. van der Ven, Mariel Vlasveld, Linka Lokker, Graham Ramsay, Alphons G.H. Kessels,

Petra van den Keijbus, Arie van Nieuw Amerongen, Enno C.I. Veerman

Accepted for publication in Crit Care Med 


\section{Abstract}

Objective: To investigate salivary flow and incidence of oral mucositis in ICU patients compared to patients admitted because of elective coronary by-pass surgery (CABG). In addition, the pattern of oropharyngeal colonization was investigated in these patients.

Design: Prospective study.

Setting: Mixed intensive care unit and cardiosurgical ward.

Patients: In this study 24 ventilated ICU patients and 20 CABG patients were included.

Measurements and Main Results: Two dental hygienists examined ICU patients for the presence of periodontal disease and mucositis on admission and subsequently every week during their stay in the ICU. At the same time stimulated salivary flow (SSF) and salivary total IgA output was measured.

Oropharyngeal cultures were obtained as well. CABG patients were examined the day before the operation, one-day, one-week and two weeks after the operation. The following results were obtained: (1) temporarily reduced post-operative SSF and total salivary IgA output in CABG patients and nearly absent SSF in ICU patients; (2) oropharyngeal colonization with potentially pathogenic micro-organisms (PPMO) in ICU and not in CABG patients; (3) the increase in mucositis index in ICU patients parallels the increase in PPMO oropharyngeal colonization, especially Enterobacteriaceae and $P$. aeruginosa.

Conclusion: absence of adequate salivary flow in intubated ICU patients causes severe xerostomia, which may contribute to the development of mucositis and oropharyngeal colonization with Gram-negative bacteria. 


\section{Introduction}

Human saliva plays a key role in maintaining the health of the oral cavity through its antimicrobial, lubricating, and buffering properties $(1,2)$. In relation to the oral flora, saliva is capable of regulating the composition of this flora by means of its antimicrobial activity creating a selective microbial clearance or adherence (3-7). Several components of saliva attribute to this antimicrobial activity, including lysozyme, lactoferrin, peroxidases, fibronectin, histatins, cystatins, proline-rich glycoproteins, slgA and mucins $(8,9)$.

Human saliva present in the oral cavity originates from the glandula parotis. submandibularis, sublingualis and minor salivary glands. During daytime unstimulated salivary flow is estimated between $0.25-0.35 \mathrm{ml} / \mathrm{min}$, which can increase to 4-6 $\mathrm{ml} / \mathrm{min}$ when stimulated by eating and chewing. When asleep salivary flow is nearly absent and falls below $0.1 \mathrm{ml} / \mathrm{min}$. The amount of saliva during the night $( \pm 10 \mathrm{ml} / 8 \mathrm{hrs})$ is accounted for by the submandibularis $(70 \%)$, sublingualis $(15 \%)$ and minor salivary glands (15\%). The mucins from these glands are responsible for the visco-elasticity of saliva. When asleep saliva becomes more viscous because the production of saliva from the glandula parotis stagnates completely. During daytime the viscosity of saliva fluctuates due to variations in secretion rate of the low-viscous parotid saliva. The daily amount of whole saliva produced based on these flow rates is between $500-600 \mathrm{ml}(10)$. Fifty percent of this amount is unstimulated whole saliva, which protects the oral cavity during most hours of the day. Hyposalivation is defined as an unstimulated salivary flow below $0.25 \mathrm{ml} / \mathrm{min}$, severe xerostomia is present when unstimulated salivary flow falls below $0.1 \mathrm{ml} / \mathrm{min}$. Salivary flow is reduced by several conditions including autoimmune diseases (Sjögren's syndrome, rheumatoid arthritis, systemic lupus erythematosus), genetic disorders, after radiotherapy in head and neck cancer patients, or dehydration due to fever, diarrhea, burns and reduced oral intake of fluids. In addition medication can play a role in the reduction of salivary flow and xerostomia, particularly by pharmaceuticals that block the central and peripheral nervous system. It is generally accepted that reduced salivary flow or lack of salivary secretion can lead to deterioration in oral health, and subsequently mucositis (11) and changes in oropharyngeal colonization. For instance in irradiated head and neck cancer patients, who often suffer from acute, severe xerostomia and mucositis, frequently oropharyngeal colonization with Gram negative bacteria (GNB) and yeasts occurs $(12,13)$. So severe mucositis, exposing basal cells and thereby unmasking receptors for bacterial adherence, seems to be a favorable condition for GNB colonization. 
Ventilator-associated pneumonia (VAP) is a common infection in intensive care unit (ICU) patients (14). In ICU patients who are on mechanical ventilation the average incidence rates of VAP ranges from 9-78\% $(15,16)$. Early-onset VAP, occurring during the first 4 days of hospital stay are often caused by Staphylococcus aureus, Haemophilus influenzae and Streptococcus pneumoniae. VAP that occurs more than 4 days after admission (late-onset) is more commonly caused by Enterobacteriaceae, Pseudomonas aeruginosa and S. aureus (14).

Oropharyngeal colonization with these potentially pathogenic micro-organisms (PPMO) and subsequently tracheal colonization, due to microaspiration, precedes VAP. Because of the protective role and host defense functions of saliva it can be hypothesized that a severe reduction of salivary flow leading to xerostomia and subsequently mucositis could attribute to oropharyngeal colonization in ICU patients.

To the best of our knowledge no one studied salivary characteristics and oral inflammation (mucositis) in ICU patients. Therefore we investigated salivary flow and incidence of oral mucositis in ICU patients compared to patients admitted because of elective coronary by-pass surgery (CABG). In addition, the pattern of oropharyngeal colonization was investigated in these patients.

\section{Materials and Methods}

\section{Patients}

The study was conducted in the ICU and cardiosurgery ward of the University Hospital Maastricht from January 1, 2000 until July 1, 2000. The study group was comprised of 24 patients who were admitted to the ICU because of the need of mechanical ventilation for at least $48 \mathrm{hrs}$, and 20 patients admitted because of elective coronary by-pass surgery. Exclusion criteria for patients admitted to the ICU and cardiosurgery ward were a history of chronic obstructive lung disease, connective tissue diseases and patients using immuno-suppressive medication including corticosteroids. All ICU and coronary artery by-pass (CABG) patients who had a history of irradiation therapy of head and neck region, surgical intervention of any of the major salivary glands, or any disease associated with salivary gland dysfunction were excluded from the study. Only ICU patients who were orally intubated were included into the study, if not, they were excluded from the study. CABG patients were excluded if not extubated within 24 hours. The Institutional Review Board approved the study and informed consent was obtained from all patients. 
The age and sex were recorded in all patients. In addition, the following characteristics in ICU patients were recorded: the length of hospital stay before admission to ICU, the acute physiology and chronic health evaluation (APACHE) II admission scores as described by Knaus et al. (17), the reason for intubation, and the number of days patients were intubated.

Antibiotic use was monitored prospectively in all ICU patients. Antibiotic prophylaxis in CABG consisted of cefazolin prophylaxis during 24 hours, the first dose being administered one hour before the operation.

Induction of general anesthesia in CABG patients was performed with etomidate, fentanyl and pavulon and maintained with morphine and propofol until normal blood temperature was reached. As normal blood temperature was reached, anesthesia was discontinued and extubation followed within 24 hours in all CABG patients included into the study. In ICU patients, the physician in charge determined duration, dose and indication of anesthetics. Patients received either propofol or midazolam in combination with morphine if indicated.

\section{Sample collection}

In ICU patients stimulated salivary samples and oropharyngeal cultures were taken within $48 \mathrm{hrs}$ after admission between $10.00 \mathrm{a}$.m. and $11.00 \mathrm{a} . \mathrm{m}$., from then on once a week until discharge from the ICU. CABG patients were sampled at 4 points in time between $10.00 \mathrm{a} . \mathrm{m}$. and $11.00 \mathrm{a} . \mathrm{m}$.; the day before the operation (Day-1), and subsequently 1 day $($ Day +1$), 7($ Day +7$)$ and 14 days (Day +14$)$ after the operation. The oral care protocol in ICU patients consisted of cleaning the oral cavity with sterile cloth drenched with $\mathrm{NaCl} 0.9 \%$ twice a day.

In ICU and CABG patients stimulated saliva was collected by means of a sterile cotton wool swab (prepared with citric acid $20 \mathrm{mg} /$ cotton wool swab), which was removed from a salivette (Sarstedt, Numbrecht, Germany) and introduced in the both pouches for 5 minutes. After removal of the swabs they were inserted into the salivette and centifugated at $5000 \mathrm{x}$ g for 5 minutes at $4{ }^{\circ} \mathrm{C}$, volume of saliva was measured with a sterile $2 \mathrm{ml}$ pipette and stored at $-20^{\circ} \mathrm{C}$ until measurement of total IgA. Stimulated salivary flow was expressed as the colleted volume in milliliter during 5 minutes. Salivary total IgA determination was performed as described before (18).

Oropharyngeal cultures were taken with a sterile swab (Copan Italia, Brescia, Italy) and directly transferred into agar transport medium and thereupon inoculated on blood agar (Becton Dickinson, Columbia agar), cysteine lactose elec- 
trolyte-deficient agar (Becton Dickinson, CLED 43331), Haemophilus selective agar, and streptococcus and staphylococcus selective agar. The number of colony. forming units (CFU) was determined semi-quantitatively by the four-quadran: method as describe previously $(19,20)$.

\section{Mucositis and Periodontal disease}

Two dental hygienists examined all patients for the presence of periodontal disease by using the Community Periodontal Index of Treatment Needs (CPITN) (21) and oral mucositis. CABG patients were examined the day before the operation (Day. 1), and subsequently 1 day $($ Day +1$), 7($ Day +7$)$ and 14 days $($ Day +14$)$ after the operation. ICU patients were examined within 48 hours after admission and subsequently once a week until discharge from the ICU. Oral mucositis was determined by means of a quantitative scale of oral mucositis adopted and modified from Tardieu et al (22) as described in Table 1. An index of mucositis was calculated by adding up the scores obtained for these parameters, ranging from 0 to 39 . The index of mucositis was transformed into four levels of mucositis: 1 to 5 ; Level 0,5 to 10; Level 1, 11 to 20; Level 2 and 21 to 39 ; Level 3.

\section{Statistical Analysis}

Data are expressed as mean \pm S.D. The Wilcoxon Rank test for paired samples was used for comparison of dependent values in time. A p-value $<0.05$ was considered significant. Spearman's coefficient with two-tailed significance levels was used for correlation analyses. 
Table 1. Scale of oral mucositis

\begin{tabular}{|c|c|c|c|c|}
\hline & Grade 0 & Grade 1 & Grade 2 & Grade 3 \\
\hline Lips & & & . & \\
\hline Aspect & Smooth, soft & Stightly wrinkied & Rough & $\begin{array}{l}\text { Tumefied, cracked } \\
\text { Ulcerated, bleeding }\end{array}$ \\
\hline Color & Pale pink & $\begin{array}{l}\text { One to several } \\
\text { reddened zones }\end{array}$ & $\begin{array}{l}\text { Red, several } \\
\text { inflammatory } \\
\text { zones, one zone } \\
\text { of desquamation }\end{array}$ & Red, bleeding \\
\hline Dryness & Humid & Slightly dry & Dry & Cracked \\
\hline
\end{tabular}

$\begin{array}{lllll}\begin{array}{r}\text { Gingiva } \\ \text { Aspect }\end{array} & \text { Smooth, glossy } & \begin{array}{l}1 \text { to } 2 \text { inflammatory } \\ \text { zones or } 1 \text { to } 2 \text { white } \\ \text { plaques }\end{array} & \begin{array}{l}\text { Whitish coating } \\ \text { Desquamation } \\ \text { Inflammatory } \\ \text { zone }(10-50 \%)\end{array} & \begin{array}{l}\text { Ulceration * } \\ \text { edema+ } \\ \text { bleeding }\end{array} \\ \text { Color } & \text { Pink } & \text { Pale } & \text { Red } & \text { Shiny red } \\ \text { Dryness } & \text { Humid } & \text { Slightly dry } & \text { Dry } & \text { Bleeding }\end{array}$

Buccal mucosa

\begin{tabular}{|c|c|c|c|c|}
\hline \multirow[t]{3}{*}{ Aspect } & \multirow[t]{3}{*}{ Pink, Smooth } & \multirow{3}{*}{$\begin{array}{l}1 \text { to } 2 \text { inflammatory } \\
\text { zones } \\
1 \text { to } 2 \text { white plaques } \\
(20 \%)\end{array}$} & Tumefied & \multirow{3}{*}{$\begin{array}{l}\text { Bleeding, ulceration } \\
\text { Inflammation }(>50 \%) \\
\text { +edema } \\
\text { White plaques }\end{array}$} \\
\hline & & & White coating & \\
\hline & & & $\begin{array}{l}\text { Desquamation } \\
(10-50 \%)\end{array}$ & \\
\hline Color & Pink & $\begin{array}{l}\text { Pink with some } \\
\text { zones }\end{array}$ & $\operatorname{Red}(>20 \%)$ & Dark red \\
\hline Dryness & Humid & Slightly dry & Dry & Ulcerated \\
\hline \multicolumn{5}{|l|}{ Tongue } \\
\hline Aspect & $\begin{array}{l}\text { Firm prominent } \\
\text { Papilla }\end{array}$ & White coating & $\begin{array}{l}\text { Heavy tumefied } \\
\text { base }\end{array}$ & $\begin{array}{l}\text { Heavy, thick, } \\
\text { tumefied }\end{array}$ \\
\hline & & $\begin{array}{l}\text { Prominent red papilla } \\
\text { Inflammatory zones } \\
\text { Marked median line }\end{array}$ & $\begin{array}{l}\text { Prominent red } \\
\text { papilla }\end{array}$ & Ulcerated, streaked \\
\hline Color & Pink & $\begin{array}{l}\text { Pink with red or } \\
\text { white zones }\end{array}$ & $\begin{array}{l}\text { Entirely red } \\
\text { with even red } \\
\text { papilla }\end{array}$ & $\begin{array}{l}\text { Extremities dark red } \\
\text { White coating } \\
\text { Vesicles, black ulcers }\end{array}$ \\
\hline Dryness & Humid & $\begin{array}{l}\text { Dry } \\
\text { Hardly mobile and } \\
\text { painful }\end{array}$ & $\begin{array}{l}\text { Very dry and } \\
\text { tumefied }\end{array}$ & Very dry and rough \\
\hline Saliva & Fluid, light & Decreased & $\begin{array}{l}\text { Thick and } \\
\text { Viscous }\end{array}$ & $\begin{array}{l}\text { Rare } \\
\text { Mouth dry }\end{array}$ \\
\hline
\end{tabular}




\section{Results}

\section{Patient Characteristics}

A total of twenty CABG patients, 14 male and 6 female, were included in the study. Mean age of CABG patients was $61 \mathrm{yrs}$, range 41-77. In all CABG patients analgesic and sedative drugs were discontinued within 12 hours after the operation. Also extubation was performed within this time period in all CABG patients. The characteristics of 24 included ICU patients are summarized in table 2.

\section{Salivary flow rate and Total salivary $\lg A$}

The mean stimulated salivary flow rate (SSF) in CABG patients showed the following results: Day-1: $2.5 \pm 0.8$, Day + 1: $0.5 \pm 0.7$, Day + 7: $1.8 \pm 1$, Day + 14: $2.5 \pm$ $0.9 \mathrm{ml} / 5 \mathrm{~min}$ (Figure 1). A significant fall in SSF was observed directly postoperative $(p<0.01)$, which gradually returned too normal within 14 days.

In 4 of 24 ICU patients, it was possible to collect stimulated saliva only during the first week of admission. In these instances the salivary flow was less than 0.5 $\mathrm{ml} / 5 \mathrm{~min}$ (Figure 2). In the other 20 patients, salivary flow was so low that we

Table 2. Characteristics of the 24 ICU patients

\begin{tabular}{ll}
\hline Characteristic & \\
\hline Male/female & $13 / 11$ \\
Mean age $(y r, \pm S D)$ & $58 \pm 18.6$ \\
APACHE II score (mean \pm SD) & $23.0 \pm 5.4$ \\
Days in hospital prior to ICU; median (range) & $0(0-13)$ \\
Time to extubation (days, mean \pm SD) & $20.4 \pm 7.5$ \\
Antibiotic use on admission; no. of patients (\%) & $12(50)^{a}$ \\
& \\
Reason for intubation; no. of patients (\%) & \\
shock & $6(25)$ \\
neurologic disease & $5(20.8)$ \\
trauma & $4(16.7)$ \\
respiratory failure & $3(12.5)$ \\
elective & $3(12,5)$ \\
pneumonia on admission & $2(8.3)$ \\
cardiovascular & $1(4.2)$ \\
\hline
\end{tabular}

a excluding prophylaxis 


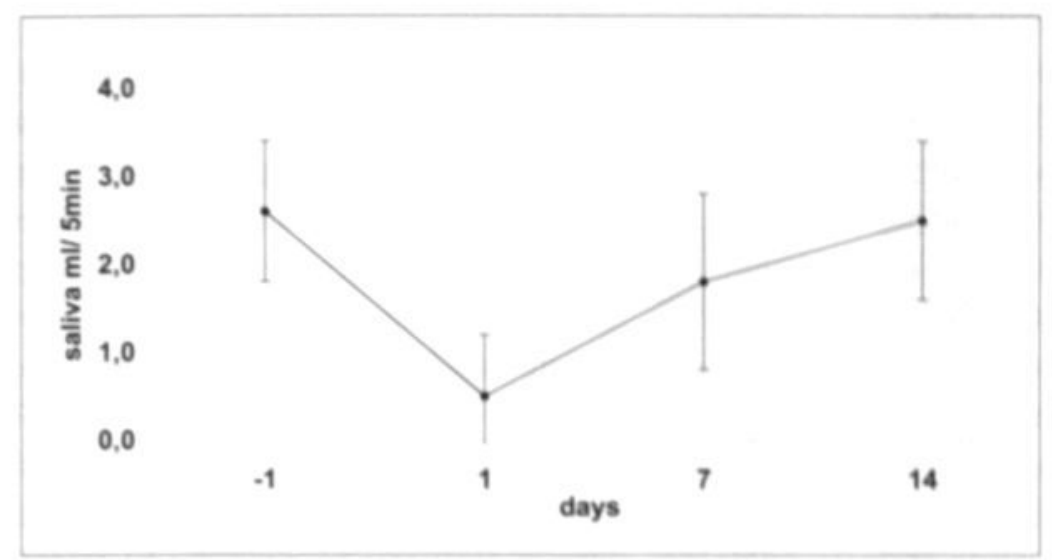

Figure. 1. Stimulated salivary flow rate in CABG patients.

were not able to collect stimulated saliva at any time. As a whole, ICU patients suffered from an almost absent SSF.

Mean salivary total IgA output (microgram per minute) decreased significantly in CABG patients the first postoperative day $(13.3 \pm 20.3 \mu \mathrm{g} / \mathrm{min})$ compared to before the operation $(22.5 \pm 16.8 \mu \mathrm{g} / \mathrm{min}, \mathrm{p}<0.05)$ but not compared to one $(19.6$ $\pm 19.7 \mu \mathrm{g} / \mathrm{min}, \mathrm{p}=0.35)$ and two weeks $(22.1 \pm 33.0 \mu \mathrm{g} / \mathrm{min}, \mathrm{p}=0.56))$ after the operation. In ICU patients salivary total IgA output could not be measured because of absent salivary flow.

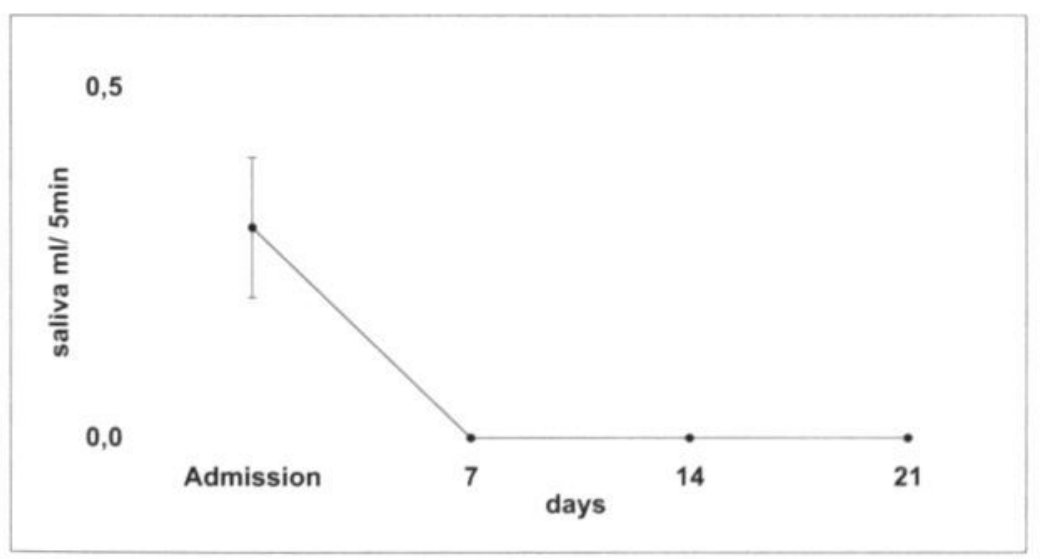

Figure. 2. Stimulated salivary flow rate in ICU patients. 


\section{Antibiotic use}

When excluding prophylaxis, 12 patients received antibiotics upon admission to the ICU. Of these 12 patients, the reasons for prescribing antibiotics upon admission were respectively, abdominal sepsis $(n=4)$, urosepsis $(n=2)$, community acquired pneumonia $(n=4)$ and pneumonia due to aspiration $(n=2)$. Abdominal sepsis was treated with amoxicillin-clavulanate and gentamycin $(n=2)$, imipenem monotherapy $(n=1)$ or ciproxin, clindamycin and gentamycin $(n=1)$. Urosepsis was treated with amoxicillin-clavulanate and gentamycin. Community acquired pneumonia was treated with amoxicillin-clavulanate. In one of these patients erythromycin was added initially because of the suspicion of a legionella infection. In 7 patients antibiotics were prescribed in the second week after admission. Vancomycin or flucloxacillin was given in 4 patients because of a bacteremia due to a central venous catheter infection. The remaining 3 patients were treated because of a nosocomial respiratory infection with the combination piperacillin and gentamycin or piperacillin-tazobactam monotherapy. In the third week after admission 2 patients received piperacillin-tazobactam because of a nosocomial respiratory infection. Three patients did not receive antibiotic therapy, when prophylaxis was excluded. In all three cases it concerned prophylaxis with flucloxacillin in neurosurgical patients.

\section{Oropharyngeal colonization}

CABG patients did not acquire PPMO alongside their normal oral flora. Calculating the percentage of ICU patients which acquired oropharyngeal colonization with $S$. aureus, $H$. influenzae, Enterobacteriaceae and $P$. aeruginosa showed an increase in patients who became colonized with the latter two (Figure 3). Analysis of the semi-quantitative oropharyngeal cultures of ICU patients are depicted in Table 3 , and showed a significant increase in $\mathrm{cfu} / \mathrm{ml}$ of Enterobacteriaceae and $P$. aeruginosa, in the second and third week after intubation.

\section{Mucositis and Periodontal disease}

Although there were subjective complaints of dry mouth in CABG patients postoperative, no signs of mucositis were documented. In ICU patients median mucositis index increased significantly in time from $2 \pm 3.2$ at admission to $19 \pm 5.9$ after 3 weeks of intubation ( $p<0.01$, Figure 4$)$. During successive weeks $79 \%$, 


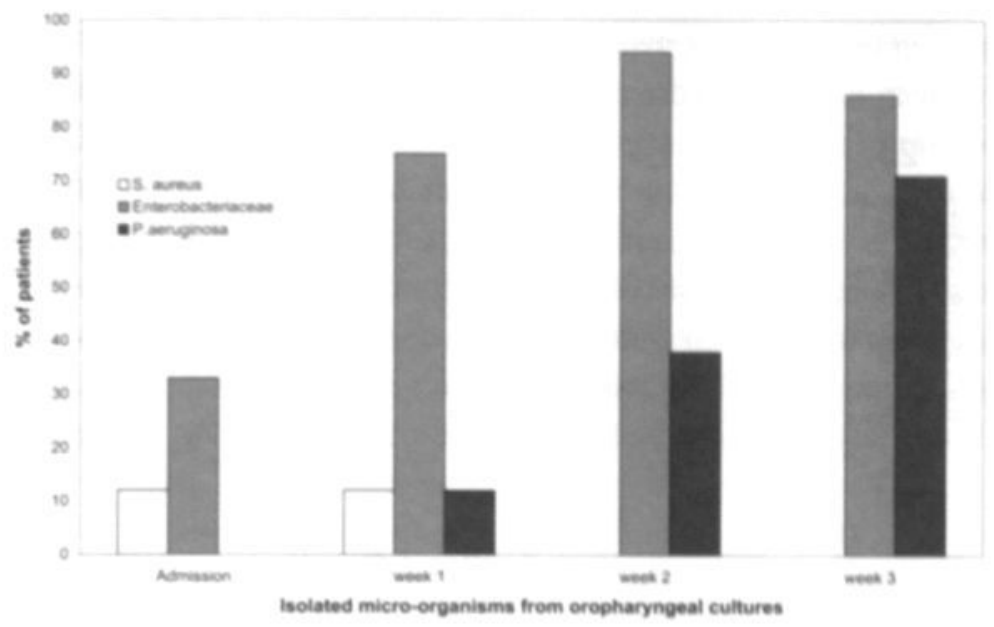

Figure. 3. Percentage of ICU patients who showed oropharyngeal colonization with S. aureus, Enterobacteriaceoe and P. aeruginosa.

Table 3. Semi quantitative oropharyngeal cultures a of isolated micro-organisms in ICU patients

\begin{tabular}{lcccc}
\hline & S. aureus $/ \mathrm{H}$. influenzoe & Enterobacteriaceoe & P. aeruginosa \\
\hline Admission & $(\mathrm{n}=24)$ & $0.5 \pm 1.5$ & $0.9 \pm 1.3$ & $0 \pm 0$ \\
Week 1 & $(\mathrm{n}=24)$ & $0.75 \pm 2.1 \mathrm{~b}$ & $4.5 \pm 4.0 \mathrm{c}$ & $0.7 \pm 1.8 \mathrm{c}$ \\
Week 2 & $(\mathrm{n}=15)$ & $0 \pm 0 \mathrm{~b}$ & $6.6 \pm 2.8 \mathrm{c}$ & $2.2 \pm 3.1 \mathrm{c}$ \\
Week 3 & $(\mathrm{n}=8)$ & $0 \pm 0 \mathrm{~b}$ & $6.1 \pm 3.5 \mathrm{c}$ & $3.3 \pm 2.8 \mathrm{c}$
\end{tabular}

\footnotetext{
${ }^{a}$ Log values expressed as mean \pm SD. Values compared to those on admission; ${ }^{b} p$-value non-significant,
} ${ }^{b} p<0.01$ and ${ }^{C} p<0.05$ significant.

$25 \%, 12 \%$ and $0 \%$ of patients remained free of mucositis (Table 4 ). No difference in mucositis index was found between dentate ICU patients and those without dentation. No change occurred in CPITN score during admission. Median CPITN score on admission between CABG and ICU patients showed no statistical difference $(2.8$ versus $3.0, \mathrm{p}=\mathrm{NS})$. 


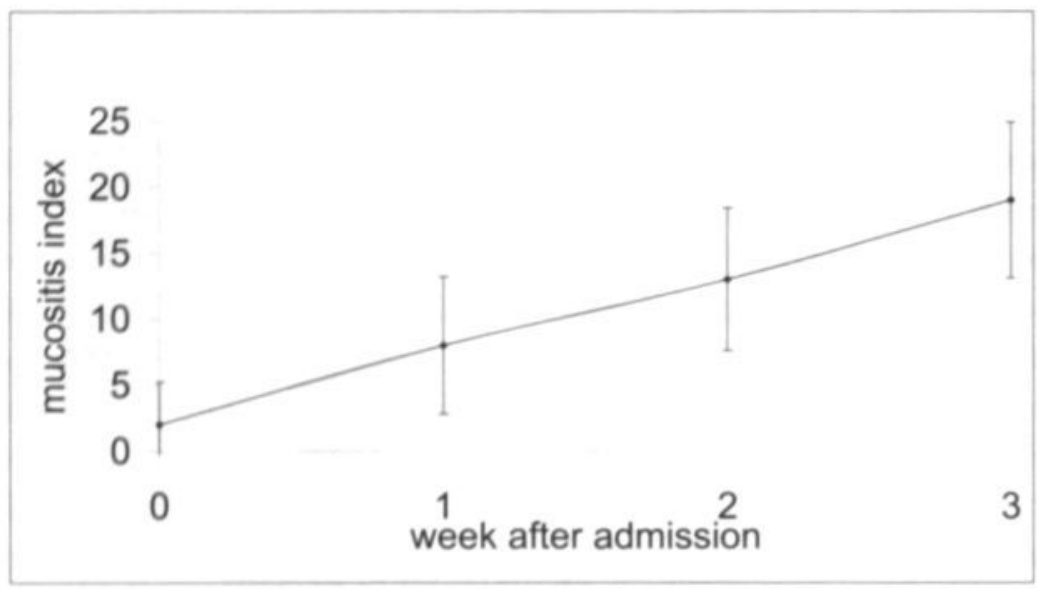

Figure. 4. Percentage of ICU patients who showed oropharyngeal colonization with S. aureus, Enterobacteriaceae and $P$. aeruginosa.

Table 4. Level of mucositis in ICU patients during the observation period.

\begin{tabular}{lcccc}
\hline Level & $\begin{array}{c}\text { Admission } \\
(n=24)\end{array}$ & $\begin{array}{c}\text { Week 1 } \\
(n=24)\end{array}$ & $\begin{array}{c}\text { Week 2 } \\
(n=16)\end{array}$ & $\begin{array}{c}\text { Week } 3 \\
(n=7)\end{array}$ \\
\hline 0 & $19(79 \%)$ & $6(25 \%)$ & $2(12 \%)$ & $0(0 \%)$ \\
1 & $4(17 \%)$ & $12(50 \%)$ & $3(19 \%)$ & $4(57 \%)$ \\
3 & $1(4 \%)$ & $5(21 \%)$ & $9(57 \%)$ & $2(29 \%)$ \\
\hline
\end{tabular}

\section{Mucositis and Oropharyngeal colonization}

Correlation analysis between mucositis index and oropharyngeal cultures revealed a significant correlation between mucositis index and Enterobacteriaceae in the second and third week $(\mathrm{r}=0.67, \mathrm{P}<0.01$ respectively $\mathrm{r}=0.55, \mathrm{P}<0.05)$ and $P$. aeruginosa in the third week $(\mathrm{r}=0,55, \mathrm{P}<0.05)$. Of the $24 \mathrm{ICU}$ patients included in this study, only 3 patients did not receive antibiotic therapy. Two of those $3 \mathrm{pa}$ tients developed a mucositis index of more than 10 points in the second week after admission and these 2 patients acquired increasing oropharyngeal colonization with Enterobacteriaceae and/or $P$. aeruginos $a$ in the second and third week after 
admission. The remaining $21 \mathrm{ICU}$ patients did receive antibiotic therapy. Eight out of those $21 \mathrm{ICU}$ patients received piperacillin in combination with gentamycin or piperacillin-tazobactam monotherapy, both highly active against gram-negative bacteria, in respectively the second and third week after admission. In all but one of those $8 \mathrm{ICU}$ patients, semiquantitative cultures showed an increase in Enterobacteriaceae and/or $P$. aeruginosa colonization in the second and third week after admission. The mucositis index of those patients increased in the second and third week after admission, ranging from $17-28$ points. The one patient that was not colonized with GNB had a mucositis index of less than 10 points.

\section{Discussion}

Three major findings emerged from this study that require comment: (1) reduced post-operative SSF and salivary total IgA ouput in CABG patients and nearly absent SSF in ICU patients; (2) differences in oropharyngeal colonization with PPMO between CABG and ICU patients: (3) the increase in mucositis index in ICU patients parallels the increase in PPMO oropharyngeal colonization, especially Enterobacteriaceae and P. aeruginosa.

The temporarily fall in SSF in CABG (figure 1) can be explained by several factors such as; postoperative stress, peri-operative changes in fluid balance, hypothermia, and adverse effects of anesthetics especially morphine $(23,24)$. CABG patients were extubated within 24 hours and resume oral intake the second postoperative day. The oral intake stimulates salivary flow and produced saliva protects the mucosa from dehydration and the development of mucositis. In addition, PPMO are rinsed out of the oral cavity. Compared to CABG patients, we documented a nearly absent salivary flow in intubated sedated ICU patients (Figure 2), which can be explained by several circumstances such as the severity of the disease resulting in intubation and admission to the ICU, lack of normal oral intake, fluid balance disturbances, extended use of morphine required because of controlled mechanical ventilation or pain management. Apart from the inadequate flow, the saliva is not distributed through the oral cavity in a supine sedated patient and severe xerostomia was therefore generally present in ICU patients.

CABG patients did not acquire oropharyngeal colonization with PPMO. This is in agreement with Niederman et al. (25) who found that normal squamous cells (from buccal mucosa) are fairly resistant to GNB adherence. Early recovery of salivary flow and the absence of mucositis in these patients possibly prevented the ad- 
herence of these microorganisms to the mucosal surfaces. A number of components (fibronectin, histatins, mucins etc.) can be measured (8) to estimate the quality of saliva; we choose to measure salivary total IgA output/min (18) in our patients as indicator of salivary output. Only the first day after CABG surgery this parameter was significantly reduced. Thereafter salivary IgA output/min did not differ from pre-operative measurements. In ICU patients it was not possible to assess salivary total IgA because of absence of adequate salivary flow. Therefore, mucosal surfaces do not only lack hydration and lubrication but also the salivary components with antimicrobial properties like lysozyme, lactoferrin, peroxidases, fibronectin, histatins, cystatins, proline rich glycoproteins, slgA and mucins $(8,9)$. The absence of these antimicrobial components may have played a role in the alteration of colonization: in the ICU patients we documented disappearance of $\mathrm{S}$. aureus, and increased GNB oropharyngeal colonization in the second and third week after admission (Figure 3).

It is tempting to assume that the documented impairment of salivary flow plays a key role in this process. Because saliva is not equally distributed in the oropharynx together with nearly absent salivary flow in ICU patients, it can be expected that the saliva that is available cannot perform its normal antimicrobial activity. The oral mucosa does not only lack the hydration and lubrication and cleansing normally provided by saliva, also diminished salivary output provides fewer antimicrobial agents to the oral cavity, which could facilitate oropharyngeal colonization with PPMO. Probably several components of saliva are essential for the prevention of colonization with PPMO. In seriously ill patients elevated salivary protease activity and reduced salivary flow, has been associated with a high susceptibility to oropharyngeal colonization by $P$. aeruginosa and adherence of Klebsiella species to human buccal epithelial cells $(26,27)$. Also fibronectin may play a role in prevention of PPMO colonization $(26,28)$, although not all studies confirm this assumption (29). In addition, it has been suggested that dental plaque in ICU patients may be an important reservoir of PPMO from where oropharyngeal colonization with PPMO occurs (30). On the other hand edentulous ICU patients not wearing dentures also showed oropharyngeal colonization with PPMO (31).

Our results demonstrate that during prolonged oral intubation ICU patients develop mucositis (Figure 4), the severity being quite comparable to mucositis recorded in irradiated head and neck cancer patients. Probably the absence of saliva plays a part in the development of mucositis in ICU patients. Wolff and coworkers, who studied subjects being evaluated in a dry mouth clinic, also found that patients with a total lack of salivary flow rarely had a normal appearing oral 
mucosa (11). The severity of the mucosal lesions was however mild in these patients. In contrast with ICU patients, these patients were not sedated and therefore able to moisture their oral cavities.

Finally we found that the severity of mucositis in ICU patients parallels with the increased oropharyngeal colonization with GNB during the second and third week of admission. This corresponds with the occurrence of late-onset GNB VAP. Although the effect of antibiotics on oropharyngeal colonization cannot be excluded, both patients with and without antibiotics directed against GNB acquired GNB oropharyngeal colonization. In these patients the increase in GNB oropharyngeal colonization parallels the increase in mucositis.

An interesting question is if prevention of mucositis can prevent GNB oropharyngeal colonization and subsequently development of VAP? Unfortunately our study was not designed to answer this question. Bergmans et al. (32) however, concluded that oropharyngeal colonization is of paramount importance in the pathogenesis of VAP, and a targeted approach to prevent colonization at this site is a very effective method of infection prevention. They performed a prospective, randomized, placebo-controlled double blind study, which showed that topical prophylaxis, without influencing gastric and intestinal colonization and without systemic prophylaxis was an effective method of preventing acquired GNB oropharyngeal colonization. Also there was a clear reduction in the incidence of VAP caused by GNB.

In conclusion, absence of adequate salivary flow in intubated ICU patients causes severe xerostomia, which may contribute to the development of mucositis and oropharyngeal colonization with GNB. The implementation of a well-developed oral care protocol in ICU patients can improve oral status (33), but the effect of such a protocol on morbidity still needs to be established.

\section{References}

1. Hatton MN, Loomis RE, Levine MJ, Tabak LA. Masticatory lubrication. The role of carbohydrate in the lubricating property of a salivary glycoprotein-albumin complex. Biochem J 1985; 230: 817-820.

2. Mandel ID. The functions of saliva. J. Dent Res 1987; 66: 623-627.

3. Gillece-Castro BL, Prakobphol A, Burlingame AL, Leffler H, Fisher SJ. Structure and bacterial receptor activity of a human salivary proline-rich glycoprotein. J Biol Chem $1991 ; 266: 17358-17368$.

4. Murray PA, Prakobphol A, Lee T, Hoover CI, Fisher SJ. Adherence of oral streptococci to salivary glycoproteins. Infect Immun 1992; 60: 31-38. 
5. Scannapieco FA, Torres GI, Levine MJ. Salivary amylase promotes adhesion of oral streptococci to hydroxyapatite. J Dent Res 1995; 74:1360-1366.

6. Reddy MS. Binding of the pili of Pseudomonas aeruginosa to a low-molecular-weight mucin and neutral cystatin of human submandibular-sublingual saliva. Curr Microbiol 1998; 37: 395-402.

7. Veerman ECI, Ligtenberg AJ, Schenkels LCPM, Walgreen-Weterings E, Nieuw Amerongen AV. Binding of human high-molecular-weight salivary mucins (MG1) to Hemophilus parainfluenzae. J Dent Res 1995; 74:351-357.

8. Schenkels LCPM, Veerman ECI, Nieuw Amerongen AV. Biochemical composition of human saliva in relation to other mucosal fluids. Crit Rev Oral Biol Med 1995; 6: 161175.

9. Hasty DL, Simpson WA. Effects of fibronectin and other salivary macromolecules on the adherence of Escherichia coli to buccal epithelial cells. Infect Immun 1987; 55: 2103 2109.

10. Nieuw Amerongen AV. Speeksel en mondgezondheid. VU press, Amsterdam 1994; 22 33.

11 Wolff A, Fox PC, Ship JA, Atkinson JC, Macynski AA, Baum BJ. Oral mucosal status and major salivary gland function. Oral Surg Oral Med Oral Pathol 1990; 70:49-54.

12. Spijkervet FK, van Saene HK, Panders AK, Vermey A, van Saene JJ, Mehta DM, Fidler V. Effect of chlorhexidine rinsing on the oropharyngeal ecology in patients with head and neck cancer who have irradiation mucositis. Oral Surg Oral Med Oral Pathol 1989; 67: 154-161,

13. Martin MV, van-Saene HK. The role of oral microorganisms in cancer therapy. Curr Opin Dent 1992; 2:81-84.

14. Craven DE, Steger KA. Ventilator-associated bacterial pneumonia: Challenges in diagnosis, treatment, and prevention. New Horiz 1998; 6: S31-45.

15. Fagon JY, Chastre J, Domart Y, Trouillet JL, Pierre J, Darne C, Gibert C. Nosocomial pneumonia in patients receiving continuous mechanical ventilation. Prospective analysis of 52 episodes with use of a protected specimen brush and quantitative culture techniques. Am Rev Respir Dis 1989; 139: 877-884.

16. Pugin J, Auckenthaler R, Lew DP, Suter PM. Oropharyngeal decontamination decreases incidence of ventilator-associated pneumonia. A randomized, placebo-controlled, double blind clinical trial. JAMA 1991; 265: 2704-2710.

17. Knaus WA, Draper EA, Wagner D.P, Zimmerman JE. APACHE II: a severity of disease classification system. Crit Care Med 1985; 13:818-829.

18. Van der Reijden WA, van der Kwaak JS, Veerman EC, Nieuw Amerongen AV. Analysis of the concentration and output of whole salivary constituents in patients with Sjogren's syndrome. Eur J Oral Sci 1996; 104:335-340.

19. Cruickshank R, Duguid JP, Marmion BP. Medical Microbiology 12th ed. 1975; 3-587.

20. Bergmans DCJ, Bonten MJM, De Leeuw PW, Stobberingh EE. Reproducibility of quantitative cultures of endotracheal aspirates from mechanically ventilated patients. J Clin Microbiol 1997; 35:796-798.

21. Rees JS, Midda M. Update on periodontology: 2. Diagnosis in periodontology. Dent Update 1992; 19:28-31. 
22. Tardieu C, CowenD, Thirion X, Franquin JC. Quantitative scale of oral mucositis associated with autologous bone marrow transplantation. Oral Oncol Eur J Cancer 1996; 32:381-387.

23. White ID, Hoskin PJ, Hanks GW, Bliss JM. Morphine and dryness of the mouth. BMJ 1989; 298:1222-1223.

24. Vickers MD, Paravicini D. Comparison of tramadol with morphine for post-operative pain following abdominal surgery. Eur J Anaesthesiol 1995; 12:265-271.

25. Niederman MS, Rafferty TD, Sasaki CT, Merrill WW, Matthay RA, Reynolds HY. Comparison of bacterial adherence to ciliated and squamous epithelial cells obtained from the human respiratory tract. Am Rev Respir Dis 1983; 127:85-90.

26. Woods DE, Straus DC, Johanson WG Jr, Bass JA. Factors influencing the adherence of Pseudomonas aeruginosa to mammalian buccal epithelial cells. Rev Infect Dis 1983; 5: S846-851.

27. Ayars GH, Altman LC, Fretwell MD. Effect of decreased salivation and $\mathrm{pH}$ on the adherence of Klebsiella species to human buccal epithelial cells. Infect Immun 1982; 38 : 179. 182.

28. Woods DE, Straus DC, Johanson WG Jr, Bass JA. Role of salivary protease activity in adherence of gram-negative bacilli to mammalian buccal epithelial cells in vivo. J Clin Invest 1981; 68:1435-1440.

29. Mason CM, Bawdon RE, Pierce AK, Dal Nogare RA. Fibronectin is not detectable on the intact buccal epithelial surface of normal rats or humans. Am J Respir Cell Mol Biol 1990; 3:563-70.

30. Scannapieco FA, Stewart EM, Mylotte JM. Colonization of dental plaque by respiratory pathogens in medical intensive care patients. Crit Care Med 1992; 20: 740-745

31. Scannapieco FA, Mylotte JM. Relationship between peridontal disease and bacterial pneumonia. J Peridontol 1996; 67:1114-1122.

32. Bergmans DC, Bonten MJ, Gaillard CA, Paling JC, van der Geest S, van Tiel FH, Beysens AJ, de Leeuw PW, Stobberingh EE. Prevention of ventilator-associated pneumonia by oral decontamination: a prospective, randomized, double blind, placebo-controlled study. Am J Respir Crit Care Med 2001; 164:382-388.

33. Fitch JA, Munro CL, Glass CA, Pellegrini JM. Oral care in the adult intensive care unit. Am J Crit Care 1999; 8: 314-318. 


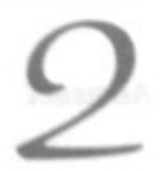

\section{Resolution of infectious parameters after antimicrobial therapy in patients with ventilator-associated pneumonia}

Paul J.W. Dennesen, André J.A.M. van der Ven, Alphons G.H. Kessels, Graham Ramsay, Marc J.M. Bonten 


\begin{abstract}
Although recommended durations of antimicrobial therapy for ventilator-associated pneumonia (VAP) range from 7 to 21 days, these are not based on prospective studies and little is known about the resolution of symptoms after start of antibiotics. Resolution of these symptoms were investigated in 27 patients. VAP was diagnosed on clinical, radiographic and microbiological criteria, including quantitative cultures of bronchoalveolar lavage. All patients received appropriate antibiotic therapy. Highest temperatures, leukocyte counts, $\mathrm{PaO}_{2} / \mathrm{FiO}_{2}$ ratios and semiquantitative cultures of endotracheal aspirates were recorded from start of therapy until day 14. Resolution was defined as the first day that these parameters fulfilled the following definition: 1) temperature $\leq 38^{\circ} \mathrm{C}$, 2) leukocytes $\leq 10 \times 10^{9} / 1,3$ ) $\mathrm{PaO}_{2} / \mathrm{FiO}_{2}$ ratio $\left.\geq 25 \mathrm{kPa}, 4\right)$ no or +1 of bacterial growth of etiologic pathogens in cultures of endotracheal aspirate. VAP was caused by Enterobacteriacea $(n=14)$, $P$. aeruginosa $(\mathrm{n}=7), S$. aureus $(\mathrm{n}=6), H$. influenzae $(\mathrm{n}=3)$, and $S$. pneumoniae $(\mathrm{n}=1)$. $H$. influenza and $S$. pneumoniae, were eradicated from tracheal aspirates, whereas Enterobacteriaceae, $S$. aureus and $P$. aeruginosa persisted, despite in vitro susceptibility to antibiotics administered. Significant improvements were observed for all clinical parameters, most apparently within the first 6 days after start of antibiotics. Newly acquired colonization, especially with $P$. aeruginosa and Enterobacteriaceae, occurred in the second week of therapy. Six patients developed a recurrent episode of VAP, four of them with P. aeruginosa. Clinical responses to therapy for VAP occur within the first six days of therapy, endotracheal colonization with Gram-negative bacteria persists despite susceptibility to therapy, acquired colonization usually occurs in the second week of therapy and frequently precedes a recurrent episode.
\end{abstract}




\section{Introduction}

Ventilator-associated pneumonia (VAP) is the most frequent ICU-acquired infection among patients receiving mechanical ventilation (1). VAP has been associated with an attributable mortality of approximately $30 \%$ depending on the pathogen isolated $(2,3)$, especially when initial antibiotic therapy is inappropriate (4). Of all antibiotics prescribed for therapy in intensive care patients, approximately $50 \%$ are administered for respiratory tract infections (5). As a result, VAP has an important impact on patient morbidity and mortality, as well as on the costs for health care.

Diagnosing VAP is problematic because of the difficulties in distinguishing colonization of the respiratory tract from infection of the lung parenchyma, and the absence of a clinically useful gold standard (6). In most ICUs the diagnosis is based on a combination of clinical, radiographic and microbiological criteria. Although the sensitivity of these criteria is high, specificity is low and antibiotics are frequently prescribed unnecessarily. The enormous use of antibiotics creates a constant threat for selection and induction of resistant pathogens and exposes patients to adverse effects. Therefore, reducing antibiotic use may have several beneficial aspects. Reductions in antibiotic use may be achieved by preventing the development of infections, optimizing the accuracy of diagnostic procedures (7), or reducing the length of treatment.

Little is known about the optimal duration of antibiotic therapy for VAP. According to guidelines from the American Thoracic Society, VAP due to $\mathrm{H}$. influenzae and methicillin-sensitive S. aureus should be treated for 7 to 10 days, whereas episodes caused by $P$. aeruginosa and Acinetobacter spp. should be treated for at least 14 to 21 days (8).

However, these recommendations are not based on the results of prospective studies. Furthermore, there is sparse information about resolution of infectious parameters associated with VAP after institution of appropriate antimicrobial therapy. Garrard and A'Court described a gradual normalization of a combination of clinical, microbiological and radiographic parameters after the institution of antibiotic therapy (9). And Montravers and coworkers demonstrated, with a second bronchoscopy three days after institution of antimicrobial therapy, that appropriate therapy results in a rapid bacteriological clearance of the distal airways. However, the effects on clinical parameters was less evident (10). The aims of the present study were to describe the clinical and microbiological response to appropriate antimicrobial therapy in patients with VAP. 


\section{Materials and Methods}

\section{Setting}

The study was conducted in the ICU of the University Hospital Maastricht from January 1, 1998 until January 1, 1999. The ICU is a 16-bed ward harboring a mixed population of medical, surgical, trauma and neurologic patients.

\section{Patients and Data collection}

All patients who received mechanical ventilation for $>48 \mathrm{hrs}$ and met the criteria for VAP (Table 1) were enrolled. Patients received empiric antibiotic treatment according to culture results of previously obtained endotracheal aspirates, and antibiotics were streamlined upon definite culture results from bronchoalveolar lavage (BAL). Empiric therapy was considered appropriate when pathogens isolated in significant amounts from BAL-samples were, in vitro, susceptible to the antibiotics. Routine surveillance included microbiological analysis of endotracheal aspirates on admission and subsequently twice weekly. The duration of antibiotic treatment was determined at the discretion of treating physicians. Demographic data (i.e. age, sex, pre-existent diseases and length of hospital stay before admis-

Table 1. Criteria used for the diagnosis of ventilator-associated pneumonia

\section{Criteria}

A $\quad 23$ positive of the following 4 :

1. rectal temperature above $38.0^{\circ} \mathrm{C}$ or below $35.5^{\circ} \mathrm{C}$

2. blood leukocytosis $\left(>10.10^{3} / \mathrm{mm}^{3}\right)$ and/or left shift or blood leukopenia $\left(<3.10^{3} / \mathrm{mm}^{3}\right)$

3. $>10$ leukocytes per high-power field in Gram stain of tracheal aspirate

4. positive culture from tracheal aspirate and

B new, persistent or progressive infiltrate on chest radiograph and

C $\quad \geq 1$ positive of the following 3 :

1. positive quantitative culture of a sample obtained by BAL (cut-off point $\geq 10^{4} \mathrm{cfu} / \mathrm{ml}$ )

2. positive blood culture unrelated to another source and obtained within $48 \mathrm{~h}$ before and after respiratory sampling

3. positive pleural fluid culture in the absence of previous pleural instrumentation

Pneumonia was diagnosed if $\mathrm{A}$ and $\mathrm{B}$ and $\mathrm{C}$ were positive. BAL, bronchoalveolar lavage. 
sion), APACHE II admission scores were assessed as described by Knaus et al. (11). Clinical, laboratory and microbiologic variables were collected daily during 14 days starting at day 0 . The following data were obtained: highest temperature, arterial oxygen tension $\left(\mathrm{PaO}_{2}\right) /$ fractional inspired oxygen $\left(\mathrm{FiO}_{2}\right)$ ratio, leukocytes in the peripheral blood, and semi-quantitative cultures of the endotracheal aspirate. In case of a clinical suspicion of VAP, endotracheal aspirates were obtained just before bronchoscopy.

\section{Microbiological analysis}

Samples of endotracheal aspirates were inoculated on blood agar (Becton Dickinson, Columbia agar), cysteine lactose electrolyte-deficient agar (Becton Dickinson, CLED 43331), Haemophilus selective agar, and streptococcus and staphylococcus selective agar. The number of colony-forming units (CFU) was determined semiquantitatively by the four quadrant method and classified as follows: no growth. $+1=10^{2} \mathrm{CFU} / \mathrm{ml}, 2+=10^{3} \mathrm{CFU} / \mathrm{ml}, 3+-10^{4} \mathrm{CFU} / \mathrm{ml}$ and $4+-10^{6} \mathrm{CFU} / \mathrm{ml}$ (10). We previously demonstrated that there is a good correlation between semiquantitative and quantitative analyses of endotracheal aspirates. All semi-quantitative cultures with $4+$ growth had quantitative culture results of $\geq 10^{6} \mathrm{CFU} / \mathrm{ml}$ $(12,13)$.

\section{Resolution of infectious parameters}

Four parameters i.e. highest temperature, leukocyte count in peripheral blood, $\mathrm{PaO}_{2} / \mathrm{FiO}_{2}$ ratio and semi-quantitative culture result of endotracheal aspirate were used to determine the resolution of infectious parameters. We adopted cut-off points for "normality" based on common clinical practice i.e. 1) highest temperature $\leq 38^{\circ} \mathrm{C}$, 2) leukocyte count in peripheral blood $\leq 10 \times 10^{3} / \mathrm{mm}^{3}$, 3) $\mathrm{PaO}_{2} / \mathrm{FiO}_{2}$ ratio $\geq 25 \mathrm{kPa}, 4)$ no or +1 of bacterial growth, of bacteria similar to those isolated from BAL samples, in semi-quantitative cultures of endotracheal aspirates. Resolution of ventilator-associated pneumonia was defined as the first day after start of therapy at which all parameters were "normal".

For additional analyses patients were grouped according to the pathogens causing VAP: community-acquired pathogens like S. pneumoniae, $H$. influenzae and S. aureus (group A); Enterobacteriaceaea (group B); and P. aeruginosa (group C). 


\section{Statistical analysis}

Kaplan-Meier analyses were used to depict the changes of infectious parameters in time. Cox-regression analysis was used to determine the prognostic value of changes of individual infectious parameters. Daily changes of these parameters per patient were analyzed with linear regression and differences were tested with the one-sample T-test. Mann-Whitney test (MW) and Kruskal-Wallis (KW) tests were used to compare groups. A p-value $<0.05$ was considered significant.

\section{Results}

Twenty-seven patients ( 16 male) fulfilled the diagnostic criteria for VAP (Table 2). Antibiotic agents used before and after bronchoscopy, microorganisms isolated from cultures from endotracheal aspirates and BAL samples, results of the chest radiographs, duration of antibiotic treatment for VAP, time to extubation, length of ICU stay and resolution of fever from individual patients are listed in Table 3. Mean duration of antibiotic treatment for VAP was $11.5 \pm 2.9$ days (median 13 days, range 7-14 days). VAP was accompanied by bacteremia in four patients (15\%). Most cases of VAP were caused by Enterobacteriaceae and P. aeruginosa, accounting for $67 \%$ of causative microorganisms; in 14 patients VAP was caused by Enterobacteriacea and in 7 patients by $P$. aeruginosa. In all, 35 bacterial species were isolated in significant amounts from BAL fluid. Seven episodes were polymicrobial (Table 3). Initial antimicrobial therapy was appropriate in all cases. Despite in vitro susceptibility of isolated pathogens to the prescribed antimicrobial therapy, infection persisted in one patient (patient 1). On suspicion of superinfection a second BAL was performed after 6 days of treatment, which, again, yielded $P$. mirabilis with susceptibility for the initial administered antimicrobial therapy. These antibiotics were continued and the patient fully recovered.

A second episode of VAP was diagnosed in 6 patients (22\%). In three patients a new pathogen (in all cases $P$. aeruginosa) was isolated, which was resistant to the antibiotics administered during the first episode. These patients (7,8 and 9) acquired tracheal colonization with $P$. aeruginosa 5, 9 and 10 days after start of antimicrobial therapy, respectively, and developed infection 4 (7 and 8) and 21 days after discontinuation of therapy. In the other three patients $(16,25,27)$ similar bacterial species as those isolated in the first episode were associated with the second episode of VAP (i.e. P. aeruginosa, Escherichia coli, and S. aureus). Only E. coli causing a new episode of VAP (patient 16), 8 days after discontinuation of 
Table 2. Baseline characteristics of the study patients

\begin{tabular}{|c|c|}
\hline \multicolumn{2}{|l|}{ Characteristic } \\
\hline Male/female & $16 / 11$ \\
\hline Mean age (yt, range) & $62.6(34-79)$ \\
\hline APACHE II score $($ mean \pm SD) & $21.8+7.4$ \\
\hline Days in hospital prior to ICU; median (range) & $11(0-37)$ \\
\hline Days in ICU; median (range) & $34(10-78)$ \\
\hline \multicolumn{2}{|l|}{ Time to extubation in days after start } \\
\hline antibiotic treatment of VAP; median (range) & $17(5-65)$ \\
\hline Antibiotic use on admission; no. of patients (\%) ${ }^{*}$ & $21(76)$ \\
\hline \multicolumn{2}{|l|}{ Undertying diseases; no. of patients (\%) } \\
\hline cardiovascular disease & $11(41)$ \\
\hline respiratory disease & $7(26)$ \\
\hline neurologic disease & $5(19)$ \\
\hline gastrointestinal disease & $4(15)$ \\
\hline neoplastic disease & $4(15)$ \\
\hline diabetes mellitus & $4(15)$ \\
\hline alcoholism or drug abuse & $2(7)$ \\
\hline renal insufficiency & $2(7)$ \\
\hline immunodeficiency & $1(4)$ \\
\hline
\end{tabular}

*Prophylaxis not included.

therapy, was resistant to the antibiotics used during the first episode. Patient 25 acquired new colonization with $S$. aureus 4 days after a 14-day course of therapy with flucloxacillin and a recurrent episode of VAP was diagnosed two days later. Finally, patient 27 received 14 days of treatment with meropenem for $P$. aeruginosa VAP. During this period, tracheal colonization persisted and pulmonary infiltrates persisted. When fever recurred 6 days after discontinuation of antibiotics, a second BAL was performed and a recurrent episode of VAP was diagnosed.

Mean durations of antibiotic treatment were comparable for patients with VAP caused or not caused by $P$. aeruginosa; $12.7 \pm 1.7$ days (median 12.5, range 7-14 
Table 3. Antibiotic (AB) agents used before and after bronchoalveolar lavage (BAL), microorganisms isolated from tracheal aspirate and BAL, duration of antibiotic treatment, results of chest radiographs, time to extubation, length of ICU stay and resolution of temperature from the moment of VAP diagnosis.

\begin{tabular}{|c|c|c|c|c|c|c|c|c|c|c|}
\hline Patient & $\begin{array}{l}\text { Previous } \\
A B\end{array}$ & $\begin{array}{c}\text { Prior } \\
\text { AB } \\
\text { indicaton }\end{array}$ & $\begin{array}{l}\text { Tracheal } \\
\text { aspirate } \\
\text { culture }\end{array}$ & $\begin{array}{l}\text { BAL Culture } \\
\text { (cfu/ml) }\end{array}$ & $\begin{array}{l}\text { AB therapy } \\
\text { after BAL }\end{array}$ & $\begin{array}{l}\text { Duration } \\
\text { AB therapy } \\
\text { in days }\end{array}$ & Chest radiograph & $\begin{array}{l}\text { Time } \\
\text { extubation } \\
\text { in days }\end{array}$ & $\begin{array}{l}\text { Length of } \\
\text { ICU stay } \\
\text { in days }\end{array}$ & $\begin{array}{l}\text { Day tem- } \\
\text { perature } \\
\leq 38^{\circ} \mathrm{C}\end{array}$ \\
\hline $1 \%$ & $\begin{array}{l}\text { Flucloxacillin } \\
\text { Ticarcillin- } \\
\text { clavulanate } \\
\text { Gentamycin }\end{array}$ & IV & P.mirabilis & $\begin{array}{l}\text { P.mirabilis } \\
\left(2.10^{4}\right)\end{array}$ & $\begin{array}{l}\text { Piperacillin } \\
\text { Gentamycin }\end{array}$ & 14 & unilateral infiltrate & 31 & 32 & 11 \\
\hline $2 \#^{*}$ & None & & $\begin{array}{l}\text { E.cloacae } \\
\text { H.influenzae }\end{array}$ & $\begin{array}{l}\text { E.cloacae } \\
\left(3.10^{4}\right)\end{array}$ & $\begin{array}{l}\text { Piperacillin } \\
\text { Gentamycin }\end{array}$ & 7 & unilateral infiltrate & 17 & 27 & 7 \\
\hline $3 \bullet$ & $\begin{array}{l}\text { Amoxicillin- } \\
\text { clavulanate } \\
\text { Gentamycin } \\
\text { Metronidazol }\end{array}$ & v & P.aeruginosa & $\begin{array}{l}\text { P. aeruginosa } \\
\left(9.10^{4}\right)\end{array}$ & Meropenem & 14 & bilateral infiltrate & 14 & 24 & 10 \\
\hline 4 & Pennicilin G & II & E.coli & $\begin{array}{l}\text { E.coli } \\
(1.105)\end{array}$ & Ciprofloxacin & 14 & bilateral infiltrate & 32 & 33 & 3 \\
\hline $5 \#$ & Flucloxacillin & I & $\begin{array}{l}\text { S.aureus } \\
\text { C.diversus }\end{array}$ & $\begin{array}{l}\text { S.aureus } \\
\text { P.aeruginosa } \\
\left(1.10^{4}\right)\end{array}$ & $\begin{array}{l}\text { Ticarcillin- } \\
\text { clavulanate }\end{array}$ & 10 & unilateral infiltrate & 11 & 12 & 2 \\
\hline 6 & $\begin{array}{l}\text { Amoxicillin- } \\
\text { clavunalate }\end{array}$ & I & $\begin{array}{l}\text { E.coli } \\
\text { E.cloacae } \\
\text { C.diversus }\end{array}$ & $\begin{array}{l}\text { E.coli } \\
\text { E.cloacae } \\
\text { C.diversus } \\
\left(1.10^{4}\right)\end{array}$ & Piperacillin & 14 & bilateral infiltrate & 17 & 48 & 2 \\
\hline
\end{tabular}




\begin{tabular}{|c|c|c|c|c|c|c|c|c|c|}
\hline $7 \# \bullet$ & $\begin{array}{l}\text { Amoxicillin- } \\
\text { clavunalate }\end{array}$ & I & S.marcescens & $\begin{array}{l}\text { S.marcescens } \\
\left(2.10^{4}\right)\end{array}$ & $\begin{array}{l}\text { Piperacillin- } \\
\text { Tazobactam }\end{array}$ & 10 & $\begin{array}{l}\text { bilateral infiltrate and } \\
\text { bilateral pleural effusion }\end{array}$ & 36 & 62 \\
\hline $8 \bullet$ & $\begin{array}{l}\text { Amoxicillin- } \\
\text { clavunalate } \\
\text { Clindamycin }\end{array}$ & VI & K.pneumoniae & $\begin{array}{l}\text { K.pneumoniae } \\
(1.106)\end{array}$ & $\begin{array}{l}\text { Amoxicillin- } \\
\text { clavunalate }\end{array}$ & 14 & bilateral infiltrate & 6 & 10 \\
\hline $9 \# \bullet$ & None & & $\begin{array}{l}\text { S.aureus } \\
\text { Streptococ. spp } \\
\text { E.coli }\end{array}$ & $\begin{array}{l}\text { S.aureus } \\
\left(1.10^{4}\right)\end{array}$ & $\begin{array}{l}\text { Amoxicillin- } \\
\text { clavunalate }\end{array}$ & 7 & unilateral infiltrate & 42 & 48 \\
\hline $10 \#$ & $\begin{array}{l}\text { Amoxicillin- } \\
\text { clavunalate }\end{array}$ & I & K.oxytoca & $\begin{array}{l}\text { K.oxytoca } \\
(1.104)\end{array}$ & Ciprofloxacin & 14 & $\begin{array}{l}\text { unilateral infiltrate } \\
\text { and pleural effusion }\end{array}$ & 17 & 18 \\
\hline $11^{*}$ & $\begin{array}{l}\text { Amoxicillin- } \\
\text { clavunalate }\end{array}$ & I & E.coli & $\begin{array}{l}\text { E.coli } \\
\text { E.cloacae } \\
\left(5.10^{4}\right)\end{array}$ & Ciprofloxacin & 14 & $\begin{array}{l}\text { unilateral infiltrate and } \\
\text { bilateral pleural effusion }\end{array}$ & 30 & 51 \\
\hline $12 \#$ & None & & S.pneumoniae & $\begin{array}{l}\text { S.pneumoniae } \\
\left(5.10^{4}\right)\end{array}$ & $\begin{array}{l}\text { Amoxicillin- } \\
\text { clavunalate }\end{array}$ & 10 & unilatreal infiltrate & 17 & 18 \\
\hline $13 \#$ & None & & S.aureus & $\begin{array}{l}\text { S.aureus } \\
(1.106)\end{array}$ & $\begin{array}{l}\text { Amoxicillin- } \\
\text { clavunalate }\end{array}$ & 14 & bilateral infiltrate & 9 & 16 \\
\hline $14 \#$ & $\begin{array}{l}\text { Erythromycin } \\
\text { Ceftazidime }\end{array}$ & II & K.pneumoniae & $\begin{array}{l}\text { K.pneumoniae } \\
(4.105)\end{array}$ & $\begin{array}{l}\text { Amoxicillin- } \\
\text { clavunalate }\end{array}$ & 12 & bilateral infiltrate & 8 & 10 \\
\hline 15 & $\begin{array}{l}\text { Amoxicillin- } \\
\text { clavunalate } \\
\text { Vancomycin }\end{array}$ & I,IV & $\begin{array}{l}\text { P.mirabilis } \\
\text { P.aeruginosa }\end{array}$ & $\begin{array}{l}\text { P.mirabilis } \\
\text { P.aeruginosa } \\
\left(2.10^{6}\right)\end{array}$ & $\begin{array}{l}\text { Piperacillin } \\
\text { Gentamycin }\end{array}$ & 11 & unilateral infiltrate & 31 & 34 \\
\hline
\end{tabular}


Table 3 - Continued

\begin{tabular}{|c|c|c|c|c|c|c|c|c|c|c|}
\hline Patient & $\begin{array}{l}\text { Previous } \\
A B\end{array}$ & $\begin{array}{c}\text { Prior } \\
\text { AB } \\
\text { indicaton }\end{array}$ & $\begin{array}{l}\text { Tracheal } \\
\text { aspirate } \\
\text { culture }\end{array}$ & $\begin{array}{l}\text { BAL Culture } \\
\text { (cfu/ml) }\end{array}$ & $\begin{array}{l}\text { AB therapy } \\
\text { after BAL }\end{array}$ & $\begin{array}{c}\text { Duration } \\
\text { AB therapy } \\
\text { in days }\end{array}$ & Chest radiograph & $\begin{array}{c}\text { Time } \\
\text { extubation } \\
\text { in days }\end{array}$ & $\begin{array}{l}\text { Length of } \\
\text { ICU stay } \\
\text { in days }\end{array}$ & $\begin{array}{c}\text { Day tem- } \\
\text { perature } \\
\leq 38^{\circ} \mathrm{C}\end{array}$ \\
\hline $17 \#$ & $\begin{array}{l}\text { Amoxicillin- } \\
\text { clavunalate }\end{array}$ & III & $\begin{array}{l}\text { S.aureus } \\
\text { H.influnzae }\end{array}$ & $\begin{array}{l}\text { S.aureus } \\
(1.107)\end{array}$ & Flucloxacillin & 13 & bilateral infiltrate & 25 & 31 & 2 \\
\hline $18 \#$ & None & & $\begin{array}{l}\text { S.aureus } \\
\text { H.influenzae }\end{array}$ & $\begin{array}{l}\text { S.aureus } \\
\text { H.influenzae } \\
\left(1.10^{7}\right)\end{array}$ & $\begin{array}{l}\text { Amoxicillin- } \\
\text { clavunalate }\end{array}$ & 8 & $\begin{array}{l}\text { unilateral infiltrate } \\
\text { and pleural effusion }\end{array}$ & 14 & 15 & 2 \\
\hline $19 \bullet$ & $\begin{array}{l}\text { Ticarcillin- } \\
\text { clavunalate } \\
\text { Flucloxacillin } \\
\text { Clindamycin } \\
\text { Vancomycin }\end{array}$ & IV,V,VII & P.aeruginosa & $\begin{array}{l}\text { P.aeruginosa } \\
\left(1.10^{5}\right)\end{array}$ & $\begin{array}{l}\text { Piperacillin } \\
\text { Gentamycin }\end{array}$ & 14 & bilateral infiltrate & 10 & 18 & 6 \\
\hline 20 & $\begin{array}{l}\text { Amoxicillin- } \\
\text { clavunalate } \\
\text { Gentamycin }\end{array}$ & v & $\begin{array}{l}\text { P.mirabilis } \\
\text { P.aeruginosa }\end{array}$ & $\begin{array}{l}\text { P.mirabilis } \\
\text { P.auruginosa } \\
(1.105)\end{array}$ & $\begin{array}{l}\text { Piperacillin } \\
\text { Gentamycin }\end{array}$ & 12 & unilateral infiltrate & 17 & 53 & 3 \\
\hline 21 & $\begin{array}{l}\text { Amoxicillin- } \\
\text { clavunalate } \\
\text { Gentamycin } \\
\text { Erythromycin }\end{array}$ & II & P.aeruginosa & $\begin{array}{l}\text { P.aeruginosa } \\
(1.105)\end{array}$ & $\begin{array}{l}\text { Piperacillin } \\
\text { Gentamycin }\end{array}$ & 14 & bilateral infiltrate & 5 & 10 & 5 \\
\hline
\end{tabular}




\section{Amoxicillin-}

I

H.influenzae

H.influenzae

(1.104)

Flucloxacillin

14

bilateral infiltrate

Sulfamethoxazole 14

bilateral infiltrate

+Trimethoprim

27- Cefazolin

I,VIII

P.aeruginosa

P.aeruginosa

Meropenem

$(1.104)$

I: Prophylaxis, either for a surgical procedure or endocarditis, II: Therapy for community-acquired pneumonia, III: Therapy for aspiration pneumonia, IV: Catheter-felated bacteremia, V: Abdominal sepsis, VI: Sepsis due to secondary wound infection after hip-surgery. VII: Sinusitis, vIII: Suspicion of broncho-pulmonary infection. \# Resolution of all infectious parameters in patients within 9 days after start of antimicrobial therapy. "Positive blood culture in patients with the same pathogen that was isolated in broncho-alveolar lavage. . Persistent infection. • Second episode of VAP. • Probable 
days) versus $11.1 \pm 3.1$ days (median 14 , range 10-14 days), respectively ( $p=0.4$, MW), and between those who did or did not experience a second episode of VAP, $10.3 \pm 3.1$ days (median 10, range 7-14 day) versus $11.5 \pm 2.8$ days, respectively (median 13, range 10-14 days) ( $\mathrm{p}=0.3 \mathrm{MW}$ ).

Seven patients died during hospitalization, and three of them died in ICU. In these three patients, VAP was diagnosed 17-59 days before death. In the other four patients, VAP was diagnosed 28-49 days before death. Therefore, in none of these patients did death seem to be directly attributable to VAP.

\section{Resolution of infectious parameters}

After institution of antibiotic therapy a gradual fall in the mean number of colonyforming units (cfu) in cultures of endotracheal aspirates was observed (Figure 1A). The bacterial load dropped from $5.4 \mathrm{CFU} / \mathrm{ml}$ on day 0 to $1.4 \mathrm{cfu} / \mathrm{ml}$ on day 15 . However, there were extreme differences when comparing individual micro-organisms. There was persistent colonization with $P$. aeruginosa in all patients, whereas bacterial colonization with $S$. aureus, $H$. influenzae and $S$. pneumoniae completely disappeared from endotracheal aspirates (Figure 2A). Tracheal colonization with Enterobacteriaceae persisted in almost half of the patients.

Interestingly, acquired tracheal colonization was demonstrated in several patients, usually during the second week of antimicrobial therapy and most frequently with $P$. aeruginosa (Figure 2B).

\section{Time to resolution}

All four parameters of infection improved significantly in time (Figure 1A-1D). On Day 0 , averages of the four variables were; leukocyte count, $14.2 \pm 5.4 .10^{3} / \mathrm{mm}^{3}$ which decreased with $0.15 .10^{3} / \mathrm{mm}^{3}$ per day $(\mathrm{p}<0.01)$; highest temperature, 38.8 $\pm 0.5^{\circ} \mathrm{C}$ which decreased with $0.05^{\circ} \mathrm{C}$ per day $(\mathrm{p}<0.01) ; \mathrm{PaO}_{2} / \mathrm{FiO}_{2}, 26.3 \pm 10.5$ $\mathrm{kPa}$ which increased with $0.8 \mathrm{kPa}$ per day $(\mathrm{p}<0.01)$; and the bacterial load in endotracheal aspirates, $5.4 \pm 1,2 \mathrm{cfu} / \mathrm{ml}$ which decreased with $0.2 \mathrm{cfu} / \mathrm{ml}$ per day $(\mathrm{p}<0.01)$. No significant differences were found when comparing the daily changes in leukocyte counts, highest temperatures and $\mathrm{PaO}_{2} / \mathrm{FiO}_{2}$ ratios between the three groups of causative pathogens of VAP (A, B, and C), not even in the first 6 days of treatment when changes were most prominent. The changes in leukocyte counts, highest temperatures and $\mathrm{PaO}_{2} / \mathrm{FiO}_{2}$ ratios were $-0.36 .10^{3} / \mathrm{mm}^{3},-0.1^{\circ} \mathrm{C}$, and $+1.2 \mathrm{kPa}$, respectively in group $\mathrm{A} ;-0.30 .10^{3} / \mathrm{mm}^{3},-0.16^{\circ} \mathrm{C}$, and $+1.4 \mathrm{kPa}$, re- 

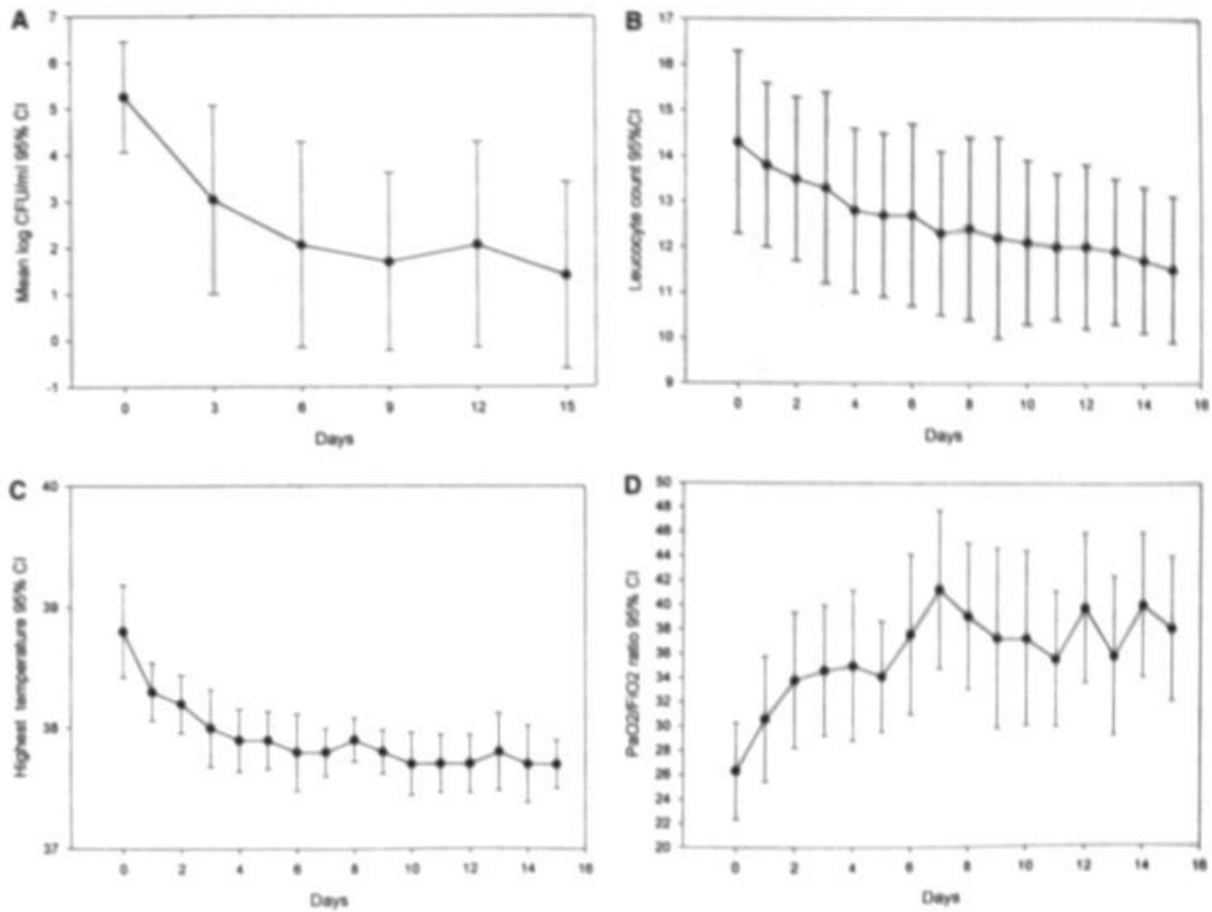

Figure 1A. Mean log colony-forming units per milliliter of endotracheal aspirate of those bacteria associated with VAP after initiation of antimicrobial treatment.

B. Leukocyte count after initiation of antibiotic treatment.

C. Highest temperature after initiation of antibiotic treatment.

D. $\mathrm{Pa}_{\mathrm{O} 2} / \mathrm{FI}_{\mathrm{O} 2}$ ratio after initiation of antibiotic treatment.

spectively in group $\mathrm{B}$; and $-0.27 .10^{3} / \mathrm{mm}^{3},-0.15^{\circ} \mathrm{C}$, and $+1.2 \mathrm{kPa}$, respectively in group C (KW, NS).

For patients with abnormalities on Day 0 in temperature $\left(>38^{\circ} \mathrm{C}, \mathrm{n}=27\right)$, $\mathrm{PaO}_{2} / \mathrm{FiO}_{2}$ ratio $\left(<25 \mathrm{kPa}, \mathrm{n}=17\right.$ ), leukocyte count $\left(>10^{3} / \mathrm{mm}^{3}, \mathrm{n}=21\right)$, and number of $\mathrm{CFU} / \mathrm{ml}\left(>10^{2}, \mathrm{n}=27\right.$ ), the mean (median) duration to resolution of these parameters was 5 (3), 6 (2), 8 (6) and 10 (7) days, respectively (Figure 3). The mean (median) duration until complete resolution (i.e. for all parameters) was 9 (8) days. When excluding microbiological eradication, the mean (median) duration of resolution for the remaining three clinical parameters was 6 (6) days. Mean duration of antibiotic treatment in this group of patients was $10 \pm 2.8$ days (me- 

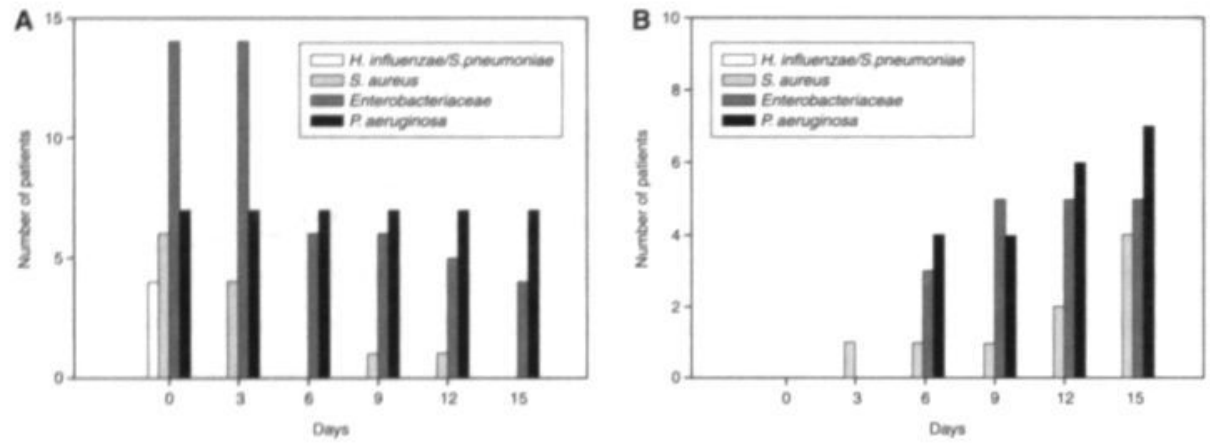

Figure 2A. Number of patients with initially isolated microorganisms from endotracheal aspirates collected in time after initiation of antibiotic treatment.

B. Number of patients with newly isolated microorganisms from endotracheal aspirates in time after initiation of antibiotic treatment.

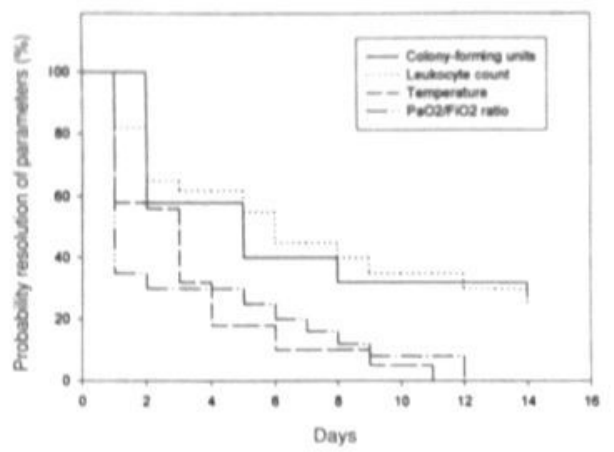

Figure 3. Probability of resolution of individual parameters after initiation of antibiotic treatment using Kaplan-Meier analysis.

dian 10 , range $7-14$ days), as compared to $13.1 \pm 2.1$ days (median 14 , range $7-14$ days) if no complete resolution occurred $(\mathrm{P}<0.01, \mathrm{MW})$.

The $\mathrm{PaO}_{2} / \mathrm{FiO}_{2}$ ratio was the only significant covariate of resolution ( $\mathrm{P} \leq 0.01$ ). The differences between the durations until resolution between groups A, B, C and between survivors and non-survivors were comparable (data not shown). 


\section{Discussion}

We described the resolution of infectious parameters after initiation of appropriate antimicrobial therapy for VAP. In general, resolution of clinical parameters is slow, most evident during the first 6 days of therapy and most apparent for the $\mathrm{PaO}_{2} / \mathrm{FiO}_{2}$ ratio. Appropriate antimicrobial therapy rapidly eradicates endotracheal colonization with $S$. pneumoniae, $H$. influenzae and $S$. aureus, but fails to eradicate colonization with Enterobacteriaceae and $P$. aeruginosa, indicating that follow-up of this parameter is an unreliable parameter for therapy success when these pathogens are involved. Moreover, tracheal colonization with resistant pathogens frequently occurs during the second week of therapy. Based on our findings, a shorter duration of antimicrobial therapy for VAP may be as effective and may reduce the risks of colonization and subsequent infection with more resistant pathogens.

There is sparse information about the clinical and microbiological response to appropriate antimicrobial therapy in patients with VAP. This may be related to the existing problems in diagnosing VAP. In clinical practice, VAP is usually diagnosed on a combination of clinical and radiographic criteria in combination with semiquantitative cultures from tracheal aspirates. The combination of these criteria has a high sensitivity for VAP, but specificity is low $(7,14)$. As a result, many patients will be incorrectly diagnosed as having VAP, and a description of resolution of clinical parameters in such a population may be influenced by patients having colonization instead of infection of the respiratory tract. In the present study, quantitative cultures from BAL were added to the combination of diagnostic criteria for diagnosing VAP. Although we realize that these methods cannot be considered as a gold standard they do represent the best clinically available tools to diagnose VAP. Moreover, a recent study demonstrated that the use of invasive techniques, as used in this study, was associated with a better patient outcome and considerable reductions in antibiotic use (7). Although we found that temperature, $\mathrm{PaO}_{2} / \mathrm{FiO}_{2}$ ratio and leukocyte counts improved significantly in time after initiation of antibiotic treatment, the resolution of these parameters was generally slow. The mean time to resolution of these clinical parameters was 6 days. These patients were treated for a shorter duration, suggesting that clinicians take these clinical parameters into account if deciding whether to continue or discontinue therapy.

In a previous study Garrard and A'Court determined the clinical response to antimicrobial therapy in 83 patients with VAP (9). The clinical response was measured by daily values of the Clinical Pulmonary Infection Score (CPIS), previously 
defined by Pugin (15). The CPIS is a combination of clinical, radiographic and $\mathrm{mi}$ crobiological criteria, with a maximum score of 12 . Values of 7 or higher are considered diagnostic for VAP. Although quantitative cultures from bronchoscopic techniques are not included in the CPIS, these techniques were used for validation of the CPIS (15). Similar to our findings, they found a gradual improvement of the CPIS during the first 9 days after commencement of antibiotic therapy (9). In another study, Montravers and coworkers observed a significant decrease in temperature and increase in $\mathrm{PaO}_{2} / \mathrm{FiO}_{2}$ ratio within 3 days of antibiotic treatment which was accompanied by eradication of bacteria from distal airways in the majority of patients, as demonstrated by repeated PSB (10).

Although interpretations of chest radiographs are important diagnostic criteria for VAP, we decided not to use this as a parameter of infection resolution. Chest radiographs are generally considered to be of limited value for defining clinical improvement in patients with pneumonia (16-18), although rapidly deteriorating abnormalities are suggestive for either progressive or recurrent episodes of VAP.

Our findings of persistent endotracheal colonization are completely different to the reported effects of antimicrobial therapy on repeated quantitative cultures from PSB, as reported by Montravers and coworkers (10). Using cultures from PSB, they demonstrated that bacteria were eradicated in distal airways in 51 of 76 patients with VAP within three days after start of antimicrobial treatment (10). These findings again emphasize that endotracheal colonization is not equivalent to infection of distal airways and that bacterial eradication from endotracheal aspirates is a poor marker for determination of clinical response of VAP, especially when caused by Gram-negative bacteria. Only when VAP is caused by $H$. influenzae or S. pneumoniae, may follow-up of endotracheal aspirates be useful.

A recurrent episode of VAP was diagnosed in six patients. The clinical response to therapy for their first episode was not different as compared to the responses observed in patients who did not develop a recurrent episode. Four of the six pathogens associated with the recurrent episodes were resistant to antibiotics used to treat the first episode, and four episodes were caused by $P$. aeruginosa. A recurrent episode of VAP, caused by $P$. aeruginosa, may result from persistent colonization, acquired colonization from exogenous sources or selection of endogenous colonization. Rello and coworkers recently described, using molecular biotyping, that recurrent episodes of VAP caused by $P$. aeruginos $a$ were frequently caused by peristence of the causative strains in the respiratory tract (19). Our findings of persistent endotracheal colonization of $P$. aeruginosa in all patients with $P$. aeruginosa VAP, despite appropriate antimicrobial therapy, fully support these findings. More- 
over, several other patients acquired tracheal colonization with $P$. aeruginosa during therapy. Although molecular biotyping was not performed in the present study, previous analyses in our ward demonstrated that colonization and infection with $P$. aeruginosa was only sporadically caused by cross-transmission, and that selection of endogenous strains, usually colonizing the intestinal tract, was a more important route of colonization (20).

Can our findings be extrapolated to ventilated patients in other settings? The etiology of bacteria causing VAP in our ward is characterized by the absence of important resistance problems, and, because of regular surveillance of tracheal aspirates, empirical therapy was in all cases appropriate. If empirical therapy would be inappropriate, as described in other studies $(2,4)$ clinical responses may be completely different or even absent. The lack of a standardized approach for antibiotic prescription and discontinuation may be a possible weakness of the present study. However, the practice as described here, is the current practice in our ICU, and was, therefore, most appropriate to investigate. Moreover, our patient population was small and causes of VAP were heterogenuous, thereby, limiting extrapolation to other patient groups.

In conclusion, (a) the clinical response to antimicrobial therapy for VAP, diagnosed with bronchoscopic techniques, occurs within the first six days of therapy, (b) colonization with Gram-negative bacteria will persist in many patients and (c) acquired colonization, predominantly with resistant pathogens, occurs mainly in the second week of therapy. Therefore, one may hypothesize that a duration of therapy for VAP of 7 days would be sufficient and could prevent recurrent colonization and infection with more resistant bacteria, such as $P$. aeruginosa. Currently, a duration of therapy of 14 to 21 days is recommended for VAP caused by Enterobacteriaceae or $P$. aeruginosa (8).

A strategy to treat VAP for 7 instead of 14-21 days should be tested in a prospective randomized study design. A shorter duration of therapy would reduce the selective pressure for colonization, and, thereby, the risks of recurrent infection with resistant pathogens. Moreover, a reduction in antibiotic use may reduce the risks of adverse drug events and help to control health care costs, in which costs for antibiotics are elementary. 


\section{References}

1. Vincent JL, Bihari DJ, Suter PM, Bruining HA, White J, Nicolas-Chanoin MH, Wolff M, Spencer RC, Hemmer M: The prevalence of nosocomial infection in intensive care units in Europe: Results of the European Prevalence of Infection in Intensive Care (EPIC) study. JAMA 1995; 274:639-644.

2. Fagon JY, Chastre J, Hance AJ, Montravers P, Novara A, Gibert C. Nosocomial pneumonia in ventilated patients: A cohort study evaluating attributable mortality and hospital stay. Am J Med 1993: 94:281-288.

3. Crouch Brewer S, Wunderink RG, Jones CB, Leeper KV. Ventilator-associated pneumonia due to pseudomonas aeruginosa. Chest 1996; 109:1019-29.

4. Luna CM, Vujacich P, Niederman MS, Vay C, Gherardi C, Matera J, Jolly EC. Impact of BAL data on the therapy and outcopme of ventilator-associated pneumonia. Chest 1997; 111:676-685.

5. Bergmans DCJJ, Bonten MJM, Gaillard CA, van Tiel FH, van der Geest S, de Leeuw PW, Stobberingh EE. Indications for antibiotic use in ICU patients: A one-year prospective surveillance. J Antimicrob Chem 1997; 39:527-535.

6. Bonten MJM, Gaillard CA, Wouters EF, van Tiel FH, Stobberingh EE, van der Geest S. Problems in diagnosing nosocomial pneumonia in mechanically ventilated patients: a review. Crit Care Med 1994; 22:1683-1691.

7. Fagon JY, Chastre J. Wolff M, Gervais C. Parer-Aubas S, Stephan F, Similowski T, Mercat A, Diehl JL, Sollet JP, Tenaillon A. Invasive and noninvasive strategies for management of suspected ventilator-associated pneumonia. A randomized trial. Ann Intern Med 2000; 18:621-30.

8. Hospital-acquired pneumonia in adults: Diagnosis, Assessment of severity, Initial antimicrobial therapy, and Preventative Strategies. A consensus statement. Am J Respir Crit Care Med 1995; 153:1711-1725.

9. Garrard CS, A'Court CD. The diagnosis of pneumonia in the critical ill. Chest 1995; 108:17S-25S.

10. Montravers P, Fagon JY, Castre J, Lesco M, Dombret MC, Trouillet JL, Gibert C. Followup protected specimen brushes to assess treatment in nosocomial pneumonia. Am Rev Respir Dis 1993; 147:38-44.

11. Knaus WA, Draper EA, Wagner DP, Zimmerman JE. APACHE II: a severity of disease classification system. Crit Care Med 1985; 13:818-829.

12. Cruickshank R, Duguid JP, Marmion BP: Medical Microbiology 1975; 12 th ed: 3-587. Churchill Livingstone, Edinburgh, Scotland.

13. Bergmans DCJJ, Bonten MJM, De Leeuw PW, Stobberingh EE. Reproducibility of quantitative cultures of endotracheal aspirates from mechanically ventilated patients. J Clin Microbiol 1997; 35:796-798.

14. Bonten MJM, Bergmans DCJJ, Stobberingh EE, van der Geest S, De Leeuw PW, van Tiel $\mathrm{FH}$, Gaillard CA. Implementation of bronchoscopic techniques in the diagnosis of ventilator-associated pneumonia to reduce antibiotic use. Am J Respir Crit Care Med 1997; 156:1820-4. 
15. Pugin J, Auckenthaler R, Mili N, Janssens JP, Lew PD, Suter PM. Diagnosis of ventilator-associated pneumonia by bacteriologic analysis of bronchoscopic and nonbronchoscopic "blind" bronchoalveolar lavage fluid. Am Rev Respir Dis 1991; 143:1121-9.

16. Fagon JY, Chastre J, Hance AJ, Guiguet M, Trouillet JL, Domart Y, Pierre J, Gibert C. Detection of nosocomial lung. infection in ventilated patients: Use of a protected specimen brush and quantitative culture techniques in 147 patients. Am Rev Respir Dis 1988; 138:110-116.

17. Wunderink RG, Woldenberg LS, Zeiss J, Day CM, Ciemins J, Lacher DA: The radiologic diagnosis of autopsy-proven ventilator-associated pneumonia. Chest 1992; 101:458-463.

18. Salata RA, Lederman MM, Shlaes DM, Jacobs MR, Eckstein E, Tweardy D, Toossi Z, Chmielewski R, Marino J, King CH. Am Rev Respir Dis 1987; 135:426-432. Diagnosis of nosocomial pneumonia in intubated, intensive care patients.

19. Rello J, Mariscal D, March F, Jubert P, Sanchez F, Valles J, Coll P. Recurrent Pseudomonas aeruginosa pneumonia in ventilated patients: relapse or reinfection? Am J Respir Crit Care Med 1998; 157: 912-916.

20. Bonten MJM, Bergmans DCJJ, Speijer H, Stobberingh EE. Characteristics of polyclonal endemicity of Pseudomonas aeruginosa colonization in intensive care units. Implications for infection control. Am J Respir Crit Care Med 1999; 160:1212-1219.

21. Bernard GR, Artigas A, Brigham KL., Carlet J, Falke K, Hudson L., Lamy M, Legall JR, Morris A, Spragg R. The American-European Consensus Conference on ARDS. Definitions, mechanisms, relevant outcomes, and clinical trial coordination. Am J Respir Crit Care Med 1994: 149:818-24. 


\section{High levels of sulfated mucins in bronchoalveolar lavage fluid of ICU patients with ventilator-associated pneumonia}

Paul J.W. Dennesen, Enno C.I. Veerman, Arie van Nieuw Amerongen, Jan A. Jacobs, Alphons G.H. Kessels, Petra van den Keijbus,

Graham Ramsay, André J.A.M. van der Ven 


\begin{abstract}
Study objective: To compared the levels of sulfated mucins in bronchoalveolar lavage fluid (BALF) in ICU patients with VAP with those in non-infectious controls; i.e ventilated ICU patients without VAP, and non-ventilated patients.
\end{abstract}

Design: Prospective study.

Setting: Mixed intensive care unit and outpatient clinic of a university hospital.

Patients: In this study 56 ventilated ICU patients with VAP, 21 ventilated ICU patients without VAP, and 26 non-ventilated outpatients with no pulmonary infection were included.

Measurements and Results: Total cell count and differential cell count of BALF samples was performed in these patients and sulfated mucin levels were measured. For this purpose we used a monoclonal antibody F2, directed against the sulfated Lewis $\mathrm{C}$ structure $\left(\mathrm{SO}_{3}-3 \mathrm{Gal} \beta 1-3 \mathrm{GlcNAc}\right)$. Sulfated mucin levels were significantly increased in ICU patients with VAP compared to those without VAP and non-ventilated patients $(p<0.05)$. No statistical difference was found between the two groups of ICU patients regarding the APACHE II score and the duration of mechanical ventilation prior to the bronchoalveolar lavage.

Conclusions: The increased levels of sulfated mucins in ICU patients with VAP are associated with infection and not with ventilation. The increase of sulfated mucins may favor the persistence of those microorganisms that posses mucine-sulfatase activity, which enable them to survive within the mucus, especially P. aeruginosa. 


\section{Introduction}

The mucosal surface of the respiratory tract is protected by a layer of mucus. Mucins are major components of the mucus layer (1). Mucins are large $(\mathrm{Mr}>$ $10,000 \mathrm{kDa}$ ) heavily glycosylated ( $>80 \%$ on weight basis) proteins that are responsible for the viscoelastic properties of the mucous gels that cover the tracheobronchial epithelial tissue. They are secreted by submucosal glands and goblet cells in the surface airway epithelium. Because of their diversity in oligosaccharide composition these respiratory mucins potentially present abundant binding sites for bacteria. Binding to these receptors may retard direct entrance to the underly. ing epithelial tissues, favoring the elimination of bacteria by the mucociliary apparatus (2). Thus mucins play an essential role in the protection of the respiratory mucosa and the prevention of bacterial colonization of the lung. Cilia can only transport mucus if it has appropriate viscoelasticity (3).

If mucus becomes to firm, as in cystic fibrosis (CF), it cannot be cleared efficiently, causing stasis, greatly increasing the incidence of bacterial infections. In early life, CF patients experience colonization and respiratory infections with Staphylococcus aureus. Later on this is followed by persistent colonization and recurrent infections with Pseudomonas aeruginosa, resulting in deterioration of lung function (4). In cystic fibrosis several groups have reported an increased sulfation and sialylation of respiratory mucins, which have been linked to $P$. aeruginosa colonization (5-7). For an overview, see (8).

Ventilator-associated pneumonia (VAP) is the most prevalent nosocomial infection in intensive care units (9). The etiologic spectrum of VAP resembles that of CF, in the first days after start of mechanical ventilation VAP is mainly caused by Streptococcus pneumoniae, Haemophilus influenzae and S. aureus. Later on a shift in etiology takes place toward Gram-negative bacteria (GNB), especially P. aeruginosa $(10,11)$. The persistence of $P$. aeruginosa in the endotracheal aspirates is responsible for the high recurrence rate of $P$. aeruginosa pneumonia in these ICU patients (12). Recently, mucin-sulfatase activity has been described in $P$. aeruginosa (13). This property enables $P$. aeruginosa to break down neutral mucin, and favors its survival and persistence within the mucus. No research has been done on mucin levels and their sulfation in patients with ventilator-associated pneumonia (VAP). Therefore we compared the levels of sulfated mucins in bronchoalveolar lavage fluid (BALF) in ICU patients with VAP with those in non-infectious controls; ventilated ICU patients without VAP, and non-ventilated patients. 


\section{Materials and Methods}

\section{Study subjects}

The study was conducted in the ICU and outpatient clinic of the University Hospital, Maastricht, The Netherlands. The mixed ICU harbors patients from the departments of surgery, internal medicine, trauma, pulmonology, neurology, and neurosurgery. The study period extended from January 1, 1998 until august 1, 1999. Data are reported for a total of 103 patients from whom a BALF sample was obtained. From 77 ventilated ICU-patients a BALF sample was obtained because of a clinical suspicion of VAP. Group no.1 $(n=56)$ consisted of ventilated ICU patients with a confirmed VAP. The diagnosis of VAP was established on the criteria listed in table 1 and in all patients from group no.1 a positive quantitative BALF culture was obtained (cutoff point $\geq 10^{4}$ colony-forming units per milliliter). In group no. 2 of ventilated ICU patients $(n=21)$, the diagnosis VAP was not confirmed because of a negative quantitative BALF culture (i.e. no growth of micro-organisms). In group no. 2 patients, the pulmonary abnormalities were attributed to non-infectious causes like ARDS, heart failure, pulmonary hemorrhages. Apart from ventilated ICU patients, also outpatients $(n=26)$ with a suspicion of interstitial lung diseases like sarcoidosis, extrinsic allergic alveolitis or idiopathic pulmonary fibrosis, were included in the study (group no.3). No infection was suspected nor diagnosed in any of group no. 3 patients.

In all patients age and sex were assessed. In ICU patients besides the APACHE II admission scores, as described by Knaus et al. (14), also the duration on mechanical ventilation prior to the BAL was recorded. Informed consent was obtained from the patient or, if this was not possible, from a representative of the family.

\section{Study design}

Patients were included in study in a prospective manner. Subsequently, they were assigned to one of the three groups as mentioned above.

\section{Sampling technique and analysis of BALF}

Bronchoalveolar lavage (BAL) was performed as described elsewhere (15). In brief, the fiberoptic bronchoscope was introduced and advanced to the bronchial orifice of a lung segment containing a new or persistent infiltrate. The fluid was instilled into the subsegment through the biopsy channel of the bronchoscope in 
Table 1. Criteria used for the diagnosis of ventilator-associated pneumonia

Criteria

A 23 positive of the following 4 :

1. rectal temperature above $38.0^{\circ} \mathrm{C}$ or below $35.5^{\circ} \mathrm{C}$

2. blood leukocytosis $\left(>10.10^{3} / \mathrm{mm}^{3}\right)$ and $/$ or left shift or blood leukopenia $\left(<3.10^{3} / \mathrm{mm}^{3}\right)$

3. $>10$ leukocytes per high-power field in Gram stain of tracheal aspirate

4. positive culture from tracheal aspirate

and

B new, persistent or progressive infiltrate on chest radiograph

and

C $\geq 1$ positive of the following 3:

1. positive quantitative culture of a sample obtained by BAL (cut-off point $\geq 10^{4} \mathrm{cfu} / \mathrm{ml}$ )

2. positive blood culture unrelated to another source and obtained within $48 \mathrm{~h}$ before and after respiratory sampling

3. positive pleural fluid culture in the absence of previous pleural instrumentation

Pneumonia was diagnosed if $\mathrm{A}$ and $\mathrm{B}$ and $\mathrm{C}$ were positive. BAL, bronchoalveolar lavage.

four aliquots of $50 \mathrm{ml}$ sterile saline $(0.9 \% \mathrm{NaCl}$, room temperature $)$ and immediately aspirated and recovered. The first fraction was not utilized for the present study and the subsequent fractions were pooled together and processed immediately. BALF was processed immediately upon arrival at the laboratory. The total cell count was performed in a Fuchs-Rosenthal haemocytometer chamber and cytocentrifuged preparations were made. Differential cell count was performed on 500 nucleated cells and included alveolar macrophages, polymorphonuclear neutrophils (PMMs), lymphocytes, eosinophils and mast cells. Both macrophages and PMNs were screened for the presence of intracellular organisms and the number of infected cells was expressed as a percentage of the 500 cell count.

Sulfated mucin in BALF was determined by ELISA, using monoclonal antibody $\mathrm{F} 2$, directed against the sulfated Lewis $\mathrm{C}$ structure $\left(\mathrm{SO}_{3}-3 \mathrm{Gal} \beta 1-3 \mathrm{GlcNAc}\right)$ (16). Since in lung secretions this epitope is expressed exclusively on sulfated mucins (16), it was considered a measure for the sulfated mucin content. Quantitative BALF culture results of isolated micro-organisms were expressed in colony-forming units per milliliter $(\mathrm{cfu} / \mathrm{ml})$. 


\section{Statistical analysis}

The results of the total cell count, differential cell count, and levels of sulfated mucins in BALF were compared between the three groups of patients using the Mann-Whitney test. To investigate if sulfated mucins could be used as a diagnostic variable for detecting VAP, we constructed a ROC-curve and calculated the area under the curve (AUC) (17). In ICU patients, the Kruskal-Wallis test was used to compare these variables for the different pathogens recovered, i.e. S. aureus, $H$. influenzae, Enterobacteriaceae and P. aeruginosa. Pearson's coefficient with twotailed significance levels was used for correlation analyses. A p-value $<0.05$ was considered significant.

\section{Results}

A total of 103 patients were included in this study, 56 ICU patients with a confirmed VAP (group no.1), 21 ICU patients without VAP (group no.2) and 26 patients from the outpatient's clinic with a non-infectious pulmonary condition (group no.3). Patients characteristics are shown in table 2.

Table 2. Characteristics of the patients.

\begin{tabular}{|c|c|c|c|c|}
\hline & $\begin{array}{l}\text { Group no.1 } \\
\qquad(n-56)\end{array}$ & $\begin{array}{l}\text { Group no.2 } \\
\qquad(n=21)\end{array}$ & $\begin{array}{l}\text { Group no.3 } \\
\qquad(n=26)\end{array}$ & $\mathrm{p}$-value \\
\hline Mean age \pm SD & $59 \pm 19$ & $58 \pm 17$ & $54 \pm 11$ & NS \\
\hline Male/Female & $26 / 30$ & $11 / 10$ & $12 / 14$ & \\
\hline $\begin{array}{l}\text { Mean days on mechanical } \\
\text { ventilation prior to } B A L \pm S D\end{array}$ & $11.4 \pm 8.8$ & $12.2 \pm 10.1$ & & NS \\
\hline Mean APACHE II score \pm SD & $20.5 \pm 7.3$ & $19.6 \pm 5.0$ & & NS \\
\hline \multicolumn{5}{|c|}{ Reason for intubation: no. of patients (\%) } \\
\hline respiratory failure & $19(34)$ & $7(33)$ & & \\
\hline shock & $12(22)$ & $4(20)$ & & \\
\hline trauma & $10(18)$ & $3(14)$ & & \\
\hline neurologic disease & $8(14)$ & $3(14)$ & & \\
\hline pneumonia on admission & $3(5)$ & $3(14)$ & & \\
\hline elective & $4(7)$ & $1(5)$ & & \\
\hline
\end{tabular}


Table 3. Total cell count, differential cell count and mucin levels in BALF from ICU patients with VAP (groep no. 1), without VAP (group no. 2) and outpatient's clinic (group no. 3).

\begin{tabular}{lcccc}
\hline & $\begin{array}{c}\text { Group no.1 } \\
(\mathrm{n}=56)\end{array}$ & $\begin{array}{c}\text { Group no.2 } \\
(\mathrm{n}=21)\end{array}$ & $\begin{array}{c}\text { Group no.3 } \\
(\mathrm{n}=26)\end{array}$ & p-value \\
\hline Total cell count* & $802 \pm 335$ & $545 \pm 149$ & $318 \pm 266$ & $<0.05$ \\
\hline Differential cell count & & & & \\
PMNs (\%) & $62.7 \pm 31.9$ & $46.8 \pm 25.9$ & $2.2 \pm 2.0$ & $<0.05$ \\
Lymphocytes (\%) & $5.1 \pm 7.5$ & $11.2 \pm 9.7$ & $3.8 \pm 2.1$ & $<0.01$ \\
Alveolar macrophages (\%) & $29.2 \pm 28.4$ & $40.8 \pm 26.5$ & $93.1 \pm 2.7$ & $<0.01$ \\
Infected cells (\%) & $6.7 \pm 10.6$ & $0.0 \pm 0.0$ & $0.0 \pm 0.0$ & $<0.05$ \\
Mucin ${ }^{\circ}(\mathrm{U} / \mathrm{ml})$ & $15.6 \pm 30.8$ & $3.1 \pm 8.4$ & $1.9 \pm 3.6$ & $<0.05$ \\
\hline
\end{tabular}

"Values expressed in $10^{3} \mathrm{~mL}^{-1}$. C Counts performed on 500 nucleated cells.

${ }^{0}$ Mucin was determined in ELISA with MAb F2, against a standard saliva, collected from fifteen individuals, which by definition contains $1 \mathrm{U} / \mathrm{mL}$.

The results of BALF total cell count, differential cell count, percentages of infected cells, and sulfated mucin levels of the three patients groups are summarized in Table 3, and expressed as mean \pm SD. In figure 1 the results of sulfated mucins for the two ventilated groups were plotted. ICU patients with VAP showed a significant increase percentage of total cell count, PMNs, infected cells, and levels of sulfated mucin in BALF compared to the other two groups ( $<<0.05)$. In BALF fluid of the outpatient's and ICU patients with VAP the percentage of lymphocytes were in the same range, but significantly lower than ICU patients without VAP $(p<0.01)$. The percentage of alveolar macrophages in BALF of the outpatient's was significantly higher compared to the other two groups of patients $(p<0.01)$. The constructed ROC curve with sulfated mucin as a test variable showed an AUC of 0.78 with a $95 \%$ CI of 0.66 to 0.91 .

No statistical difference was found between the two groups of ICU patients regarding the APACHE II score and the duration on mechanical ventilation prior to the BAL. Comparison of sulfated mucin levels in ICU patients without VAP who were ventilated for less than 7 days with those who were ventilated for more than 7 days revealed no statistical difference (data not shown ).

In ICU patients with VAP the following micro-organisms, in order of frequency, were recovered from bronchoalveolar lavage: Enterobacteriaceae $(\mathrm{n}=16)$, . aeruginosa $(\mathrm{n}=16)$, S. aureus $(\mathrm{n}=12), H$. influenzae $(\mathrm{n}=3)$. Nine VAPs were polymi- 


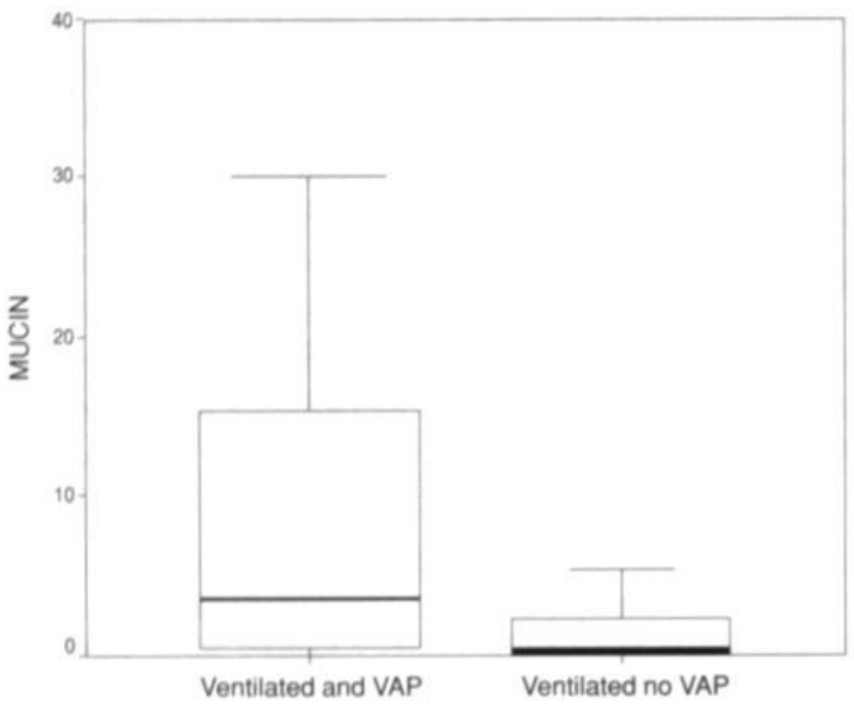

Figure 1. Sulfated mucin levels in ventilated patients with and without VAP. The condensed horizontal line indicates the median sulfated mucin levens.

crobial. Comparing the BALF results of different groups of recovered pathogens in patients with VAP, revealed no statistical difference. Correlation analysis excluded a relation between the percentage of PMNs, number of $\mathrm{cfu} / \mathrm{ml}$, days of mechanical ventilation at the one hand and the levels of sulfated mucins at the other.

\section{Discussion}

In this study we found increased concentrations of sulfated mucins in BALF of ICU patients with VAP. The mean sulfated mucin levels were 5 times higher than in ICU patients without VAP. No differences in the duration of mechanical ventilation prior to the bronchoalveolar lavage or APACHE II score were found between the two groups of ICU patients. In both groups no correlation was found between the duration of mechanical ventilation and the levels of sulfated mucin. When sulfated mucin levels of the two non-infectious control groups (ventilated versus non-ventilated patients) were compared, no statistical difference was found. Also the type of causative microorganism in ICU patients with VAP, did not influence levels of sulfated mucin. Therefore, the increase in levels of sulfated mucins in ICU patients 
with VAP are associated with infection and not with ventilation. Also the severity of the underlying disease and chronic health status (APACHE II score) does not seems to attribute to this increase in sulfated mucins levels.

These findings may not only be relevant for the pathogenesis but also for the diagnosis of VAP. The value AUC calculated from the ROC curve with sulfated mucin as a test variable indicates that this test is able to discriminate between the presence or absence of VAP in intubated patients and may therefore be used as an early screening test before culture results are available. Furthermore, this test may reflect the intensity of inflammation and microbiological burden of pneumonia, especially in patients under antimicrobial therapy. Apart from this, possibly the test can also be applied to endotracheal aspirate and closer investigations in that sense may address issues like early non-invasive diagnosis of VAP, selection of patients for an invasive procedure or follow-up of patients under antibiotic therapy. The results can be obtained within the hour and this may direct the decision whether or not to start antimicrobial therapy almost instantaneously. Results of culture take 24-48 hrs and are influenced by antibiotic therapy. However, our study has some limitations, we did not score the presence of pulmonary co-morbidities, ARDS or if patients received prior antimicrobial therapy. Therefore the influence of these variables on levels of sulfated mucins can not entirely be excluded.

Animal reports showed that tracheal intubation or mechanical injury by itself causes mucin prodution $(18,19)$. However, we did not find an increase in sulfated mucins levels in those ICU patients who were intubated and mechanical ventilated without VAP. Although the effect of intubation on the sulfated mucin cannot be excluded entirely, we believe it is of minor importance.

We used a F2 antibody, which measures sulfated mucin produced by MUC5B cells in the airway submucosal glands. Data of Wickstrom et al suggest that in lung the F2 epitope is associated exclusively with MUC5B (20). On basis of the present findings, we cannot tell whether the observed increase in sulfated mucin content is due to increased secretion of MUC5B mucins, or an increase in degree of sulfation.

Primarily we were interested in sulfated mucin levels in BALF of ICU patients with VAP compared to non-infectious controls, because $P$. aeruginosa possesses a mucin-sulfatase (13). This enzyme removes part of the sulfate content from sulfated mucins and make them more susceptible to further enzymatic degradation $(21,22)$. This property may favor persistence of $P$. aeruginosa within the mucus, which could explain the recurrent respiratory $P$. aeruginos $a$ infections in ventilated ICU patients (12).

Also CF patients suffer from recurrent bacterial infections $(23,24)$, especially 
those caused by $P$. aeruginosa, and experience reduced clearance of mucus. Respiratory secretions of these patients are initially colonized with $S$. aureus, $S$. pneumoniae and $\mathrm{H}$. influenzae, which is soon followed by persistent colonization of mucus with $P$. aeruginosa. Modifications of the mucus, like increased sulfation and sialylation of mucins in CF patients have been linked to the persistent colonization of $P$. aeruginosa $(4-6,25)$. This increased sulfation has been attributed to the primary gene defect in CF, eliminating the influence of inflammation (26). But others, however demonstrated the importance of inflammation in relation to hypersulfation (25).

Also ventilated ICU patients have impaired mucus transport (27). Furthermore, due to orotracheal intubation mucosal injury occurs in these patients, promoting $P$. aeruginosa adherence (28-29). Like in CF, ventilated ICU patients become initially colonized with $S$. aureus, $S$. pneumoniae and $H$. influenzae shortly after initiation of mechanical ventilation. As duration of mechanical ventilation progresses, a shift toward GNB, especially Enterobacteriaciae and $P$. aeruginosa is observed. Once these patients acquire $P$. aeruginosa there is a high persistence of $P$. aeruginosa in endotracheal secretions (30).

It is tempting to speculate that during VAP the increased levels of sulfated mucins not only contribute to the altered rheological properties of mucins, increasing tenacity of mucins and impeding mucociliary clearance (31), but also favor the coloinzation of $P$. aeruginosa, which is capable of breaking down these mucins (13). Normally sulfation of mucins protects them from bacterial degeneration unless bacteria also have mucin-sulfatase activity (13).

In summary, we found increased levels of sulfated mucins due to respiratory infections in ventilated ICU patients, supporting the role of inflammation in hypersulfation as described in CF (25). The increase of sulfated mucins may favor the persistence of those micro-organisms that posses mucine-sulfatase activity, which enable them to survive within the mucus. The recent discovery of a mucine-sulfatase in $P$. aeruginosa could explain part of the persistence of this microorganism in $\mathrm{CF}$ and ventilated ICU patients. 


\section{References}

1. Rose M.C. Mucins: structure, function, and role in pulmonary diseases. Am J Physiol 1992; 263:LA13-LA29.

2. Meezaman D, Charles P, Daskal E, Polymeropoulos MH, Martin BM, Rose MC. Cloning and analysis of cDNA encoding a major airway glycoprotein, human tracheobronchial mucin (MUC5). J Biol Chem 1994; 269:12932-12939.

3. Silverberg A. On mucociliary transport. Biorheology 1990; 27:295-307.

4. Armstrong DS, Grimwood K, Carzino R, Carlin JB, Olinsky A, Phelan PD. Lower respiratory infection and inflammation in infants with newly diagnosed cystic fibrosis. BMJ 1995: 310:1571-1572.

5. Boat TF, Cheng PW, lyer R, Carlson DM, Polony I. Human tract secretions: mucous gly. coproteins of nonpurulent tracheobronchial secretions and sputum of patients with bronchitis and cystic fibrosis. Arch Biochem Biophys 1976;177: 95-104.

6. Lamblin G, Lafitte JJ, Lhermitte M, Degand P, Roussel P. Mucins from cystic fibrosis sputum. Mod Probl Paediat 1977; 19:153-164.

7. Chace KV, Flux M. Sachdev GP. Comparison of physicochemical properties of purified mucus glycoproteins isolated from respiratory secretions of cystic fibrosis and asthmatic patients. Biochemistry 1985: 24:7334-7341.

8. van Nieuw Amerongen A, Bolscher JGM, Bloemena E, Veerman EC. Sulfomucins in the human body. Biol Chem 1998; 379:1-18

9. Vincent JL, Bihari DJ, Suter PM, Bruining HA, White J, Nicolas-Chanoin MH. Wolff M, Spencer RC, Hemmer M. The prevalence of nosocomial infection in intensive care units in Europe. Results of the European prevalence of infection in intensive care (EPIC) study. JAMA 1995; 274:639-644.

10. Fagon J, Chastre J, Domart Y, Trouillet JL, Pierre J, Darne C, Gibert C. Nosocomial pneumonia in patients receiving continuos mechanical ventilation: prospective analysis of 52 episodes with the use of a protected specimen brush and quantitative culture technique. Am Rev Respir Dis 1989; 139:877-884.

11. Rello J, Quintana E, Ausina V, Castella J, Luquin M, Net A, Prats G. Incidence, etiology, and outcome of nosocomial pneumonia in mechanical ventilated patients. Chest 1991; 100:439-444.

12. Rello J, Mariscal D, March F, Jubert P, Sanchez F, Valles J, Coll P. Recurrent Pseudomonas aeruginosa pneumonia in ventilated patients. Relapse or reinfection? Am J Respir Crit Care Med 1998; 157:912-916.

13. Jansen H, Hart CA, Rhodes JM, Saunders JR, Smalley JW. A novel mucin-sulphatase activity found in Burkholderia cepacia and Pseudomonas aeruginosa. J Med Microbiol 1999; 48:551-557.

14. Knaus WA, Draper EA, Wagner DP, Zimmerman JE. APACHE II: a severity of disease classification system. Crit Care Med 1985; 13:818-829.

15. Cobben NA, Jacobs JA, van-Dieijen-Visser MP, Mulder PG, Wouters EF, Drent M Diagnostic value of BAL fluid cellular profile and enzymes in infectious pulmonary disorders. Eur Respir J 1999; 14:496-502. 
16. Veerman ECI, Bolscher JGM, Appelmelk BJ, Bloemena E, van den Berg TK, Nieuw Amerongen AV. A monoclonal antibody directed against high $\mathrm{Mr}(\mathrm{r})$ salivary mucins recognizes the $\mathrm{SO}_{3}-3 \mathrm{Gal} \beta 1-3 \mathrm{GlcNAc}$ moiety of sulfo-Lewis ${ }^{\mathrm{a}}$ : a histochemical survey of human and rat tissue. Glycobiology 1997: 7:37-43.

17 Hanley JA, McNeil BJ. The meaning and use of the area under a receiver operating characteristic (ROC) curve. Radiology 1982; 143:29-36.

18. Lee HM, Takeyama K, Dabbagh, Lausier JA, Ueki IF, Nadel JA. Agarose plug instillation causes globlet cell metaplasia by activating EGF receptors in rat airways. Am J Physiol Lung Cell Mol Physiol 2000; 278:L185-92.

19. Shimizu T, Nishihara M, Kawaguchi S, Sakakura Y. Expression of phenotypic markers during regeneration of rat tracheal epithelium following mechanical injury. Am J Respir Cell Mol Biol 1994; 11:85-94.

20. Wickstrom C, Davies JR, Eriksen GV, Veerman EC, Carlstedt I.MUC5B is a major gelforming, oligomeric mucin from human salivary gland, respiratory tract and endocervix: identification of glycoforms and C-terminal cleavage. Biochem J 1998; 334:685693.

21. Robertson AM, Wright DP. Bacterial glycosulphatase and sulphomucin degradation. Can J Gastroenterol 1997; 11:361-366.

22. Houdret N, Ramphal R, Scharfman A, Perini JM, Filliat M, Lamblin G, Roussel P . Evidence for the in vivo degradation of human respiratory mucins during Pseudomonas aeruginosa infection. Biochem Biophys Acta 1989; 992:96-105.

23. Niederman MS, Ferranti RD, Zeigler A, Merrill WW, Reynolds HY. Respiratory infection complicating long term tracheostoma. Chest 1984; 85:39-44.

24. Rivera M, Nicotra MB. Pseudomonas aeruginosa mucoid strain. Its significance in adult chest diseases. Am Rev Respir Dis 1982: 126:833-836.

25. Davril M, Degroote S, Humbert P, Galabert C, Dumur V, Lafitte JJ, Lamblin G, Roussel P The sialylation of bronchial mucins secreted by patients suffering from cystic fibrosis or from chronic bronchitis is related to the severity of airway infection. Glycobiology 1999; 9:311-321

26. Zhang Y, Doranz B, Yankaskas JR, Engelhardt JF.Genotypic analysis of respiratory mucous sulfation defects in cystic fibrosis. J Clin Invest 1995; 96:2997-3004.

27. Konrad F, Schreiber T, Brecht-Kraus D, Georgieff M. Mucociliary transport in ICU patients. Chest 1994: 105:237-241.

28. Ramphal R, Small PM, Shands Jr JW, Fischlschweiger W, Small PA Jr . Adherence of Pseudomonas aeruginosa to tracheal cells injured by influenza infection or by endotracheal intubation. Infect Immun 1980; 27:614-619.

29. Bentzmann S, Plotkowski C. Puchelle E. Receptors in the Pseudomonas aeruginosa adherence to injured and repairing airway epithelium. Am J Respir Crit Care Med 1996; 154:S155-S162.

30. Crouch-Brewer S, Wunderink RG, Jones CB, Leeper KV Jr . Ventilator-associated pneumonia due to Pseudomonas aeruginosa. Chest 1996; 109:1019-29.

31. Strous GJ, Dekker J . Mucin-type glycoproteins. Crit Rev Biochem Mol Biol 1992; 27: 57-92. 


\section{4}

\section{Non-specific Cytoplasmic Cytomegalovirus Antigen detection after Coronary Bypass Surgery}

Paul J.W. Dennesen, André J.A.M. van der Ven, Marinus Blok, Jos G. Maessen, Alphons G.H. Kessels, Graham Ramsay, Cathrien A. Bruggeman 


\section{Introduction}

After primary infection, like all herpesviruses, cytomegalovirus (CMV) has the ability to persist in the host as a latent virus.

Peripheral blood mononuclear cells (PBMCs) have been identified as a site of CMV latency (1). Recently, reactivation of latent CMV from PBMCs has been described (2). Tumour necrosis factor-alpha (TNF- $\alpha$ ) seems to play a key role in the reactivation of latent CMV (3). Interestingly, CMV seropositivity has been associated with an increased risk for restenosis after coronary atherectomy (4). Because coronary bypass grafting ( $C A B G$ ) is a highly stressful event with systemic release of TNF- $\alpha$ (5), it could be a favourable condition for CMV reactivation in these patients.

To test this hypothesis, we performed a prospective study to investigate the incidence of $\mathrm{CMV}$ reactivation in patients undergoing elective $\mathrm{CABG}$.

\section{Materials and methods}

Between November 1999 and January 2000, 30 patients admitted at our hospital for elective CABG were included in this study. The day before the operation, 7 and 14 days after the operation, blood samples were drawn from each patient. Additional CMV serological screening was performed 3 months after the operation. At the same time urine and saliva samples were collected. Sera of patients were analysed for the presence of IgM and IgG against CMV using the AxSYM assays (Abbott Laboratories, USA), as described elsewhere (6). PBMCs were isolated using the Ficoll-paque (Pharmacia Biotech, Sweden) separation technique for immunocytology and polymerase chain reaction (PCR). For detection of CMV antigens in PBMCs, immunocytology was performed as described by Asadullah et al. (7) using monoclonal antibodies (MoAbs) directed against CMV immediate early antigen-1 (Clonab ${ }^{\star}$ CMV IE1, clone: BS500; Biotest, Germany), pp65 early matrix protein (Clonab ${ }^{\star} \mathrm{CMV}$, clone $\mathrm{C} 10 / \mathrm{C} 11$; Biotest, Germany and clone BM 222 (6)). Several isotype-matched irrelevant MoAbs served as negative controls. PBMCs obtained from renal transplant patients with CMV disease served as a positive controls. Binding of MoAbs was detected by the standard alkaline phosphatase anti-alkaline phosphatase (APAAP) complex (Dakopatts, Denmark) (7). For each MoAb a total of 500 PBMCs were screened by microscopy. For the detection of CMV in urine and saliva a conventional isolation technique was used as described by Kraat 
et al. (8). For PCR, DNA was isolated from PBMCs, urine and saliva using the Wizard genomic DNA purification Kit (Promega Corporation, USA) according to the direction of manufacturer. For PCR of EDTA-blood, DNA was isolated as described by Boom et al. (9). The primers used were directed against the IE1 region generating a fragment of $603 \mathrm{bp}$. Fifty cycles of amplification were carried out. The PCR was able to detect 5 copies of control CMV-DNA (data not shown). Confirmation of the PCR results was performed by Southern hybridisation with a biotinylated oligonucleotide and enhanced chemiluminescance detection (Amersham, UK). Detection of CMV-mRNA (pp67 and IE1) in EDTA-blood was performed as described previously (10).

\section{Statistical analysis}

Results are expressed as median $\pm \mathrm{SD}$. The Wilcoxon test for paired samples was used for comparing the frequencies of antigen-positive cells on the three time points. The differences were considered significant at $\mathrm{P}<0.05$.

\section{Results}

Of the 30 CABG patients included in this study, 2 patients withdrew from the study, leaving 28 eligible patients. Presence of CMV IgG-antibodies were detected in 21 of the 28 patients. No seroconversion or significant titer rise of CMV IgG-antibody level was observed during the study. At all time points conventional cultures of urine and saliva revealed no infectious virus.

PCR was used to further investigate the presence of $\mathrm{CMV}$ in various samples. This CMV PCR was first validated in 10 renal transplant patients. In these patients we were able to detect CMV-DNA in PBMCs before or at the same time cell culture and pp65 antigenemia became positive (data not shown).

Culture results of urine and saliva samples were also negative PCR. This excludes that low amounts of virus were excreted after the operation. Furthermore, all collected blood samples that were tested for the presence of CMV-DNA by PCR yielded negative results. Also, we were not able to detect the presence of CMVmRNA (IE1 and pp67) in these blood samples by means of a highly sensitive amplification technique (10). Because PBMCs are believed to be a site of latency from which reactivation can take place (1), we also looked for the presence of CMV in PBMCs of these patients by PCR. However, in none of these samples CMV-DNA was detectable. 


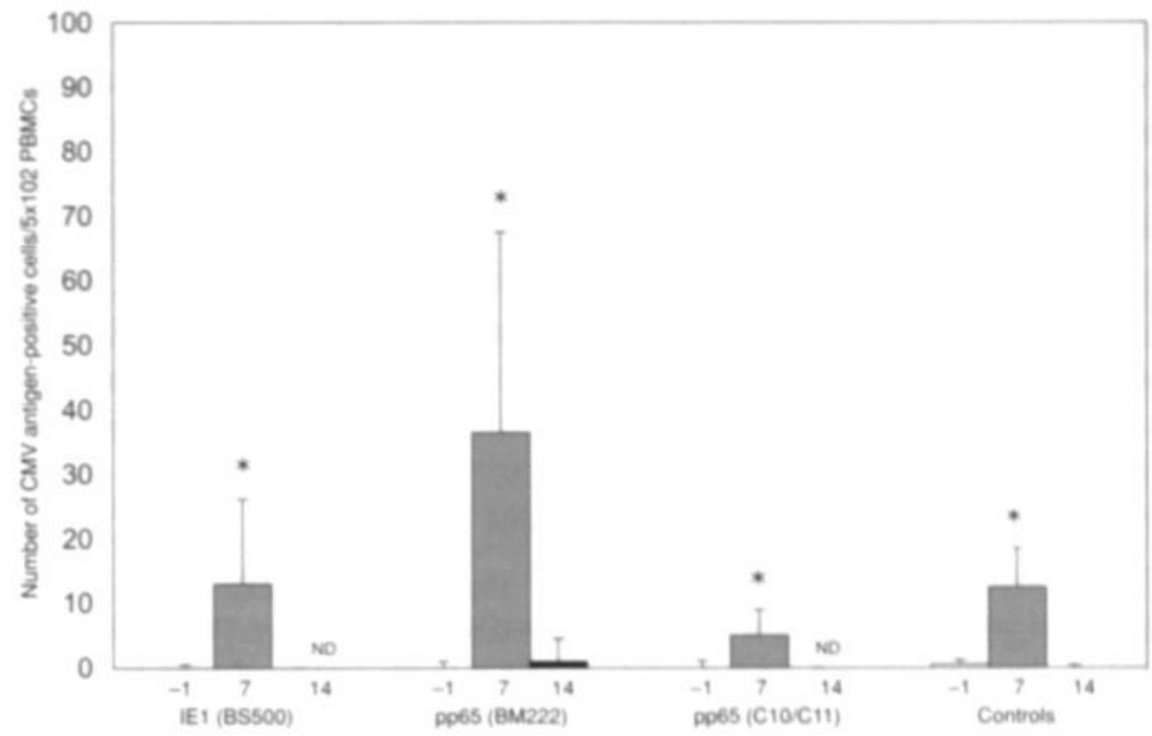

Figure 1. The number of IE1-, pp65- (clone BM222 and $\mathrm{C} 10 / \mathrm{C} 11$ ) and control-positive PBMCs on the day before coronary bypass surgery and 7 and 14 days after surgery in seropositive patients. ND, not detectable. ${ }^{*} P<0.005$

In contrast to the negative culture and PCR results, CMV antigen positive PBMCs were detected in 20 seropositive- and in 4 seronegative patients using the technique described by Asadullah et al. (7). Seropositive patients showed a significant increase in the median number of CMV antigen-positive PBMCs one week after the operation for the three different MoAbs (Fig. 1). In 2 of the 4 seronegative patients, significant numbers of CMV antigen-positive PBMCs were detected one week after the operation. As shown in figure 1, CMV antigen-positive PBMCs were also found in those samples in which irrelevant isotype matched MoAbs were used as negative controls.

\section{Discussion}

In our patients we were able to demonstrate a significant increase in CMV-antigen positive PBMCs one week after the operation. Prösch et al. described similar findings $(3,7,11)$, as they detected CMV-antigen positive PBMCs with identical MoAbs, in transplant recipients, septic patients and recently in patients with moderate to 
severe chronic plaque psoriasis. However we question if the cytoplasmatic staining by means of the APAAP complex in PBMCs indeed indicates CMV reactivation, and propose that this is a rather aspecific phenomenon, not related to CMV. This conclusion was based on several findings. First, CMV antigen-positive PBMCs were detected in CMV-seronegative patients. Second, no CMV-IE and pp67mRNA could be detected by means of a highly sensitive NASBA assay. Third, CMV-DNA was not detected in whole blood and separately isolated PBMCs by PCR. Finally, neither CMV IgM-antibodies, nor a significant rise in the CMV IgG-antibody levels was present within 3 months after surgery. An explanation for the described results could be that MoAbs directed against CMV bind to Fcy-receptors of polymorphonuclear leukocytes and mononuclear cells in an aspecific way (12). Nevertheless, our study does have some limitations. First of all, the timing and frequency of sampling may have been inadequate to pick up rare events of CMV reactivation. Furthermore we did not measure TNF- $\alpha$ levels systematically.

However, in a recent study, which demonstrated CMV reactivation in patients with acute myocardial infarction, a comparable sample frequency was used (13) and CMV reactivation was found to be associated with strongly elevated cathecholamine but normal TNF- $\alpha$ plasma levels. Beside elevated TNF- $\alpha$ plasma levels, elevated cathecholamine levels have also been reported in CABG patients (14). Finally, CMV transmission through blood products is a possibility that cannot be excluded in our patients. Despite these possible shortcomings, we conclude that CMV reactivation does not occur after elective cardiac bypass surgery. Although antibodies directed against CMV reacted with antigens in the cytoplasm of PBMCs from CABG patients, this was not found to be specific.

\section{References}

1. Taylor-Wiedeman J, Sissons JGP, Borysiewicz LK, Sinclair JH. Monocytes are a major site of persistence of human cytomegalovirus in peripheral blood mononuclear cells. J Gen Virol 1991; 72:2059-2064.

2. Soderberg-Naucler C, Fish KN, Nelson JA. Reactivation of latent human cytomegalovirus by allogeneic stimulation of blood cells from healthy donors. Cell 1997; 91:119-26.

3. Döcke WD, Prösch S, Fietze E, Kimel V, Zuckermann H, Klug C, Syrbe U, Krüger DH, von Baehr R, Volk HD. Cytomegalovirus reactivation and tumour necrosis factor. Lancet 1994: 343:268-69.

4. Zhou YF, Leon MB, Waclawiw MA, Popma JJ, Yu ZX, Finkel T, Epstein SE. Association between prior cytomegalovirus infection and the risk of restenosis after coronary atherectomy. N Engl J of Med 1996; 335:624-30. 
5. Butler J, Rocker GM, Westaby S. Inflammatory response to cardiopulmonary bypass. Ann Thor Surg 1993: 55:552-559.

6. Blok M. Goossens VJ, Vanherle SJ, Top B, Tacken N, Middeldorp JM, Christiaans MH, van Hooff JP: Bruggeman CA. Diagnostic value of monitoring human cytomegalovirus late pp67 mRNA expression in renal-allograft recipients by nucleic acid sequence-based amplification. J Clin Microbiol 1998; 36:1341-6.

7. Asadullah K, Prösch S, Audring H, Büttnerova I, Volk HD, Sterry W, Döcke WD. A high prevalence of cytomegalovirus antigenaemia in patients with moderate to severe chronic plaque psoriasis: an association with systemic tumour necrosis factor alpha overexpression. Br J Dermatol 1999; 141:94-102.

8. Kraat YJ, Christiaans MH, Nieman FH, van den Berg-Loonen PM, van Hooff JP, Bruggeman CA. Risk factors for cytomegalovirus infection and disease in renal transplant recipients: HLA-DR7 and triple therapy. Transpl Int 1994; 7:362-7.

9. Boom R, Sol CJA, Salimans MMM, Jansen CL. Wertheim-van Dillen PME, van der Noordaa J. Rapid and simple method for purification of nucleic acids. J Clin Microbiol 1990; 28:495-503.

10. Blok MJ, Christiaans MH, Goossens VJ, van Hooff JP, Sillekens P, Middeldorp JM, Bruggeman CA. Early detection of human cytomegalovirus infection after kidney transplantation by nucleic acid sequence-based amplification. Transplantation 1999; 67: 1274-7.

11. Fietze E, Prösch S, Reinke P, Stein J, Döcke WD, Staffa G, Loning S, Devaux S, Emmrich $\mathrm{F}$; von-Baehr R, Krüger DH, Volk HD. Cytomegalovirus infection in transplant recipients. The role of tumor necrosis factor. Transplantation 1994; 58:675-80.

12. Hornef MW, Hackstein H, Kirchner H, Bein G. Significance of cytoplasmic staining in the cytomegalovirus pp65 antigen test. European Journal of Clinical Microbiology and Infectious Diseases 1999; 18:66-68.

13. Prösch S, Wendt CE, Reinke P, Priemer C, Oppert M, Krüger DH, Volk HD, Döcke WD. A novel link between stress and human cytomegalovirus (CMV) infection: Sympathetic hyperactivity stimulates CMV activation. Virology 2000; 272: 357-65.

14. Plunkett JJ, Reeves JD, Ngo L, Bellows W, Shafer SL, Roach G, Howse J, Herskowitz A, Mangano DT. Urine and plasma catecholamine and cortisol concentrations after myocardial revascularization. Modulation by continuous sedation. Multicenter Study of Perioperative Ischemia (McSPI) Research Group, and the Ischemia Research and Education Foundation (IREF). Anaesthesiology 1997; 86: 785-96. 


\section{Reactivation of human cytomegalovirus and herpes simplex virus frequently occurs in non-immune compromised patients admitted to the intensive care}

Paul J.W. Dennesen, Cathrien A. Bruggeman, Hubert G.M. Niesters, Marinus J. Blok, Jan A. Jacobs, Graham Ramsay, André J.A.M. van der Ven 


\begin{abstract}
There are limited systemic studies of the incidence of herpes virus infections in intensive care patients. Therefore we conducted a prospective study in a multidisciplinary intensive care unit (ICU). Sixty non-immune compromised ICU patients were monitored for the occurrence of cytomegalovirus (CMV) and herpes simplex virus (HSV) infections. We obtained blood, urine, saliva and possibly BAL samples of patients admitted to the ICU and subsequently once every week until discharge from the ICU or death. Serological tests, nucleic acid sequence-based amplification (NASBA) and polymerase chain reaction (PCR) and conventional cell culture were applied. CMV or HSV was present in respectively $19 \%(n=8)$ and $28 \%(n=14)$ of ICU patients. Especially septic ICU patients were at risk of developing a CMV or HSV reactivation, which was detected in respectively $23 \%(7 / 30)$ and $27 \%(8 / 30)$ of these patients. CMV and HSV infection were associated with a prolonged requirement of mechanical ventilation (respectively, 23 days and 17 days) compared to those without reactivation (respectively 9 days and 7 days, $\mathrm{P}<0.05$ ). Whether these herpes infections affect outcome still has to be elucidated.
\end{abstract}




\section{Introduction}

Depending on the country of residence and social economic status, $40-100 \%$ of the adult population is infected with human cytomegalovirus (CMV) and herpes simplex virus (HSV), as shown by the presence of detectable antibodies $(1,2)$. CMV and HSV are ubiquitous herpesviruses that have the ability to establish a life long latent infection after the primary infection. Reactivation of herpes viruses may lead to the production of a number of restricted viral genomes but may also result in full viral replication with shedding of the virus(3). Reactivation, however, does not always cause well-defined clinical symptoms.

CMV rarely causes overt disease in healthy individuals but on the other hand, CMV can cause serious and life-threatening problems in immune-compromised patients (4). Pneumonitis, hepatitis and retinitis are common manifestations of CMV in transplant recipients or AIDS patients, but symptomatic disease without organ involvement is also recognized. CMV has well documented immunosuppressive effects, resulting in the impairment of humoral and cellular immunity (5). Shedding of $\mathrm{CMV}$ is readily detected in urine of adolescents with an asymptomatic primary CMV infection (6). In immune-compromised patients, like transplant recipients, it has been proclaimed that urinary and salivary shedding of CMV is a marker of CMV infection and survival (7). In AIDS patients, salivary shedding of CMV occurs especially if oral symptoms are present (8). CMV has also been cultured from the lower respiratory tract, and can be found in $17 \%$ of immune-compromised patients, especially those who are suspected of a pulmonary infection (9).

In healthy adults, recurrent HSV-1 infections mainly cause gingivostomatitis while HSV-2 mainly causes genital lesions. HSV pulmonary infections have been reported in surgical patients (10). Immune-compromised patients, such as transplant recipients, are at greater risk of developing severe oral mucositis (11) and to disseminate HSV to visceral organs like the lung (12). Asymptomatic salivary and genital shedding of HSV has been reported in healthy subjects as well as in immune-compromised individuals $(13,14)$.

Patients admitted to the intensive care unit (ICU) are generally not considered immune- compromised. These patients are therefore seldom suspected of CMV or HSV disease.

Recent reports however, have shown a high incidence of CMV reactivation in non-immune- compromised critically ill ICU patients $(15,16)$. These studies were limited by the fact that only septic patients and patients with a high Simplified Acute Physiology Score (SAPS) were included. 
We, however, conducted a prospective clinical study on the incidence of CMV and HSV reactivation in our multidisciplinary ICU from admission to the ICU until discharge.

For this purpose we collected at regular intervals, saliva, urine and blood samples and if available broncho-alveolar lavage (BAL) samples from admission to the ICU and thereafter. Blood samples were investigated for the presence of CMV and HSV. Shedding of these viruses in the respiratory tract, saliva and urine was documented by means of viral culture.

\section{Materials and Methods}

\section{Patients and study design}

The study was conducted in a 16-bed, multidisciplinary ICU of the University Hospital Maastricht from November 1999 to April 2000. Only non-immune compromised ICU patients, with an expected duration of ICU stay of at least 7 days, and a need for mechanical ventilation, were included into the study. ICU patients on immunosuppressive drugs were excluded from the study. A total of 60 patients were included into the study, characteristics are shown in Table 1. The study was approved by the Institutional Ethics Committee. Informed consent was obtained from the patient or, if this was not possible, from a representative of the family.

To monitor the occurrence of CMV and HSV reactivation, we prospectively obtained blood, urine, and saliva of patients admitted to the ICU within 24-36 hrs after admission and subsequently once every week until discharge from the ICU or death. If no saliva could be collected because of xerostomia, an oral swab was taken. Saliva was collected with a salivette (Sarstedt, Numbrecht, Germany). Additionally, all bronchoalveolar lavage (BAL) samples collected during admission from ICU patients who were suspected of ventilator-associated pneumonia were tested for the presence of HSV and CMV. The BAL procedure was described elsewhere (17). In brief, the fiberoptic bronchoscope was introduced and advanced to the bronchial orifice of a lung segment containing a new or persistent infiltrate. The first fraction was not utilized for the present study and the subsequent fractions were pooled together and processed immediately upon arrival at the laboratory.

Blood samples of both patient groups were analyzed for the presence of antiCMV and anti- HSV specific antibodies, CMV-mRNA, CMV and HSV DNA, using serological tests, nucleic acid sequence-based amplification (NASBA) and polymerase chain reaction (PCR), respectively. 
Table 1. Patients characteristics of all patients, and according to CMV or HSV infection.

\begin{tabular}{|c|c|c|c|}
\hline & All patients & CMV infection & HSV infection \\
\hline \multicolumn{4}{|l|}{ Characteristic } \\
\hline Sex, Male/female & $28 / 32$ & $3 / 5$ & $6 / 8$ \\
\hline Mean age $(y r, \pm S D)$ & $60.6 \pm 16.4$ & $66.1 \pm 14.1$ & $58.8 \pm 15.7$ \\
\hline APACHE II score (mean \pm SD) & $23 \pm 7$ & $24 \pm 7 / 22 \pm 7$ & $23 \pm 6 / 22 \pm 7$ \\
\hline $\begin{array}{l}\text { Median days in hospital prior to } \\
\text { ICU admission (range) }\end{array}$ & $1(0-32)$ & $1(0-10)$ & $2(0-14)$ \\
\hline Median days in the ICU (range) & $13(4-44)$ & $21(5-34)$ & $17(4-39)$ \\
\hline $\begin{array}{l}\text { Median duration of mechanical } \\
\text { ventilation in days (range) }\end{array}$ & $12(1-39)$ & $23(5-36)$ & $16(5-39)$ \\
\hline \multicolumn{4}{|l|}{ Admission diagnosis } \\
\hline \multicolumn{4}{|l|}{ Surgery } \\
\hline Aortic aneurysm & 6 & 0 & 2 \\
\hline Anastomotic leak & 5 & 1 & 1 \\
\hline Hollow viscus perforation & 7 & 1 & 0 \\
\hline Multiple trauma & 8 & 1 & 3 \\
\hline \multicolumn{4}{|l|}{ Internal and pulmonary medicine } \\
\hline Community acquired pneumonia & 8 & 4 & 3 \\
\hline Nosocomial pneumonia & 4 & 0 & 0 \\
\hline Cholangitis & 1 & 1 & 1 \\
\hline Acute pancreatitis & 3 & 0 & 1 \\
\hline Coma hepaticum & 1 & 0 & 1 \\
\hline \multicolumn{4}{|l|}{ Neurosurgery } \\
\hline Intracranial bleeding & 8 & 0 & 2 \\
\hline Head injury & 5 & 0 & 0 \\
\hline Other & 4 & 0 & 0 \\
\hline
\end{tabular}

Additionally peripheral blood mononuclear cells (PBMCs) were isolated from blood samples and tested for the presence of CMV and HSV DNA by PCR. Presence of infectious viruses in urine, saliva and BAL samples of patients was detected by means of conventional cell culture.

A CMV reactivation was defined by positive results of one or more of the following items: seroconversion, anti-CMV IgM, a significant rise (at least fourfold) in the anti-CMV IgG level compared to admission, detection of CMV mRNA, DNA or positive viral culture. CMV infection could be further classified as primary infection or reinfection due to reactivation of latent virus, depending on whether the patient was CMV seronegative or positive on admission. 
A HSV reactivation was defined by positive results of one or more of the following items: cell culture, seroconversion, positive anti-HSV IgM, a two fold rise in anti-HSV-IgG level in samples collected at an interval of at least 7 days, detection of HSV DNA or positive viral culture. As for CMV infection, HSV infection was classified as primary or secondary depending on the presence of antibodies on admission.

At entry into the study the hospital records of each patient admitted to the ICU were reviewed. The following data were noted: age, sex, the Acute Physiology and Chronic Health Evaluation II score (18), admission diagnosis, duration of mechanical ventilation, length of hospital stay before admission to the ICU, duration of admission to the ICU and final clinical outcome. Patients admitted to the multidisciplinary ICU were scored for the presence of a systemic inflammatory response syndrome (SIRS), sepsis, severe sepsis and septic shock, according to the criteria of the American College of Chest Physicians/Society of Critical Care Medicine (19):

1. SIRS, the systemic inflammatory response to a variety of severe clinical insults. The response is manifested by $\geq 2$ of the following conditions:
a) temperature $>38^{\circ} \mathrm{C}$ or $<36^{\circ} \mathrm{C}$;
b) heart rate $>90$ beats $/ \mathrm{min}$;
c) respiratory rate $>20$ breaths $/ \mathrm{min}$ or $\mathrm{PaCO}_{2}<32 \mathrm{mmHg}$;
d) white blood cell count $>12 \times 10^{3} / \mathrm{mm}^{3}$ or $<4 \times 10^{3} / \mathrm{mm}^{3}$.

2. Sepsis. The systemic response to infection. The response is manifested by the same criteria for SIRS, in the presence of an infection.

3. Severe sepsis. Sepsis associated with organ dysfunction, hypoperfusion, or hypotension. Hypoperfusion and perfusion abnormalities may include, but are not limited to, lactic acidosis, oliguria, or an acute alteration in mental status.

4. Septic Shock. Sepsis associated with hypotension, despite adequate fluid resuscitation, along with the presence of perfusion abnormalities as listed for severe sepsis.

\section{Laboratory procedures}

CMV and HSV serology

Sera were tested for the presence of $\operatorname{lgM}$ and IgG antibodies against CMV and HSV. CMV antibodies were detected (AxSYM assay, Abbott Laboratories, Illinois, USA) as described elsewhere (20). Results of the anti-CMV IgM assay were expressed as index values. Sera with index values of $>0.5$ were considered positive. Anti-CMV- 
IgG levels were expressed as numbers of antibody units (AU) per ml. Anti-CMVIgG levels of $\geq 15 \mathrm{AU} / \mathrm{ml}$ were considered positive.

For the detection of HSV antibodies an enzyme immunoassay (Enzygnost) was used (Dade Behring, Marburg, Germany) as described by Gutiérrez et al.(21). Both anti-HSV-IgM titer and anti-HSV-IgG titer of $>0.2$ were considered positive.

\section{Detection of infectious virus}

For the detection of infectious CMV or HSV in urine, saliva and BAL fluid, cell culture was used as described by Kraat et al. (22). Hel-cells (Bio Whittaker, Walkersville, USA) and Vero-cells were used for CMV and HSV detection respectively. Briefly, samples were put on top of the cellmonolayers, containing Minimal Essential Medium (MEM) supplemented with $1 \%$ Fetal Calf Serum (FCS) and centrifuged at $250 \mathrm{x} \mathrm{g}$ for 30 minutes at $20^{\circ} \mathrm{C}$. The supernatant was discharged and MEM containing $2 \%$ New-born Calf Serum (NCS) was added. Shells were incubated in a $\mathrm{CO}_{2}$ stove at $36^{\circ} \mathrm{C}$. Medium was refreshed twice a week for 6 to 8 weeks. A positive result was scored if a characteristic cytopathogenic effect of virus in the cells was detected.

\section{DNA isolation from urine}

For the isolation of DNA from urine and saliva the Wizard genomic DNA purification Kit ( Promega Corporation, Madison, USA) was used as suggested by the manufacturer. The purified nucleic acids were eluted in a total volume of $50 \mu \mathrm{l}$ of which $5 \mu$ was used for PCR.

\section{DNA and RNA isolation from blood}

Hundred $\mu \mathrm{l}$ of EDTA-blood was added to $900 \mu \mathrm{l}$ guanidine-isothiocyanate buffer. From this sample total nucleic acid was isolated as described by Boom et al. (23) The purified nucleic acids were eluted in a total volume of $50 \mu \mathrm{l}$ of which $5 \mu \mathrm{l}$ was used for PCR.

DNA isolation from peripheral blood mononuclear cells (PBMCs)

PBMCs were isolated using the Ficoll-paque (Pharmacia Biotech, Uppsala, Sweden) separation technique. Two $\mathrm{ml}$ of venous EDTA blood was gently layered on top of 4 $\mathrm{ml}$ Ficoll-paque and centrifuged at $600 \mathrm{x} \mathrm{g}$ for 20 minutes at $20^{\circ} \mathrm{C}$. The layer of PBMCs was collected using a sterile $2 \mathrm{ml}$ pipette and suspended in $5 \mathrm{ml}$ ice-cold erythrocyte lysing solution. After incubation for 10 minutes at $4{ }^{\circ} \mathrm{C}$, the suspension was centrifuged at $300 \mathrm{x} \mathrm{g}$ for 10 minutes at room temperature. The pellet was re- 
suspended in $0.01 \mathrm{M}$ PBS, pH 7.2 and washed twice $\left(300 \mathrm{x} \mathrm{g}, 10\right.$ minutes at $\left.20^{\circ} \mathrm{C}\right)$. After this procedure the pellet was resuspended in $1 \mathrm{ml}$ PBS and PBMCs were counted using the Sysmex M-2000 (Charles Goffin, Tiel, the Netherlands). One ml cell suspension containing $10^{6}-10^{7}$ cells was centrifuged at $2000 \mathrm{rpm}$ for 5 minutes at room temperature using the Micro 22R (Hettich, Tuttlingen, Germany). Subsequently, the supernatant was discharged and the remaining pellet was stored at $-70^{\circ} \mathrm{C}$. Isolation of DNA from the stored cell pellet was used as described above.

\section{Detection of CMV mRNA in blood by NASBA}

Isolation, amplification and detection of pp67 mRNA, expressed from the UL65 open reading frame of $\mathrm{CMV}$, was performed accordingly as described previously (20). Isolation, amplification and detection of IE1 mRNA transcripts was performed as for pp67 mRNA, but for the IE1 amplification two primers directed to exon 4 of the major IE1 gene were used (24).

\section{Detection of CMV DNA in blood by PCR}

We set up a PCR using the forward primer P813 (5'-GCAGACTCTCAGAGGATCG GCCCCC-3'), and reverse primer P234 (5'-GCGGGAGATGTGGATGGCTTGTAT TAAGGA-3') to amplify a 603 bp DNA fragment corresponding to a part of the exon 4 of the major IE-1 gene.

To be able to control PCR reactions for the presence of inhibitors, we generated control DNA by PCR, corresponding to position 171,021 - 172,971, in the genome of the CMV AD169 strain (25). The PCR control DNA contains the annealing sites for the primers P234 and P813. The PCR reactions for the detection of CMV were performed in duplicate. One of these reactions was spiked with 50 copies of the control DNA to check for the presence of PCR inhibitors.

The reaction was performed in a total volume of $50 \mu \mathrm{l}$, containing $0.1 \mu \mathrm{M}$ of primer P234 and P813, 0.1 mM dNTPs, 1x HotStarTaq PCR buffer (Qiagen, containing $1.5 \mathrm{mM} \mathrm{MgCl}_{2}$ ), additional $3 \mathrm{mM} \mathrm{MgCl}_{2}, 1.25$ units HotStarTaq polymerase (Qiagen) and $5 \mu \mathrm{l}$ of the purified nucleic acids. A reaction with water instead of nucleic acids was included as a negative control. As a positive control a dilution series of the control DNA was included. PCR was carried out in a DNA thermal cycler using the following cycles: 1 cycle of $15 \mathrm{~min}$ at $95^{\circ} \mathrm{C}$; 50 cycles of $30 \mathrm{sec}$ at $95^{\circ} \mathrm{C}, 30 \mathrm{sec}$ at $70^{\circ} \mathrm{C}$, and $30 \mathrm{sec}$ at $72^{\circ} \mathrm{C}$. After the last cycle, primer extension was continued for 5 min at $72^{\circ} \mathrm{C}$ to allow all templates to be completed. The amplification products were analysed by agarose gel electrophoresis and ethidium bromide staining.

The PCR products were spotted and hybridized with a $5^{\prime}$-biotinylated probe 
CMV-PCR-PR (5'-AGA GAG ACA AGG TGC TCA CGC) for conformation. Hybridization signals were visualized using streptavidin-peroxidase and electro chemiluminescence (ECL) detection reagents (Amersham, Little Chalfont, United Kingdom).

The sensitivity and specificity of the PCR was tested respectively, by using control DNA and DNA isolated from cultures of Herpes simplex virus type 1 and 2 , Epstein-Barr virus, Human Herpesvirus-6 and 7, and Varicella-Herpes Zoster virus. The CMV-PCR was able to reliably detect at least 5 copies of the control DNA. No cross-reactivity of this PCR with described herpes viruses was found (data not shown).

\section{HSV Polymerase Chain Reaction Amplification}

For this purpose a Real-Time TaqMan assay was used. Primers for the detection of HSV type 1 were published before $(26,27)$. The sequences for HSV type 2 , were newly designed using Primer Express software (Applied Biosystems, Nieuwerkerk aan de Ussel, The Netherlands). The sequences used for HSV2 were located in the $\mathrm{gD}$ gene and generated an amplification product of 71 base pairs (forward primer $5^{\prime}$-CGCCAAATACGCCTTAGCA, reverse primer 5'-GAGGTTCTTCCCGCGAAAT, fluorogenic probe $5^{\circ}$-CTCGCTTAAGATGGCCGATCCCAA TC with a FAM reported molecule). All PCR amplification reactions were performed in a $50 \mu \mathrm{l}$ volume containing 2x TaqMan universal mastermix, $45 \mathrm{pmol} / \mu \mathrm{l}$ forward primer, $2.5 \mathrm{pmol}$ reverse primer, 5 pmol Taqman probe and $10 \mu$ isolated DNA. After preparing of the reaction tubes, the whole plate holder was centrifuged for 1 minute at $1000 \mathrm{~g}$ at room temperature in a swing out rotor (Hettich Rotina 48R, Tuttlingen, Germany) to remove small air bubbles in the vessels. The amplification and detection was performed with an ABI Prism 7700 Sequence Detection System (Applied Biosystems, Nieuwerkerk aan de IJssel, The Netherlands). After incubation for 2 minutes at $50^{\circ} \mathrm{C}$ with uracil $\mathrm{N}^{\prime}$-glycosylase to inactivate possible PCR contaminants from former reactions, the reaction tube was incubated for 10 minutes at $95^{\circ} \mathrm{C}$ to inactivate the uracil N'-glycosylase and to release the activity of the AmpliTaq Gold DNA polymerase. The PCR cycling program consisted of 42 two-step cycles of 15 seconds at $95^{\circ} \mathrm{C}$ and 60 seconds at $60^{\circ} \mathrm{C}$. Real time measurements were taken and a threshold cycle $(\mathrm{Ct})$ value for each sample was calculated by determining the point at which the fluorescence exceeded a threshold limit of 0.04 . Each run contained several negative controls (no template), a positive control containing a known viral copy number based on an electron microscopic counted standard. 


\section{Statistical analysis}

Data are expressed as median \pm SD. The length of stay in the ICU, requirement for mechanical ventilation, the presence of sepsis and mortality rate was compared between patients with and without CMV or HSV reactivation by using the MannWhitney test.

\section{Results}

\section{Patients characteristics}

Sixty ICU patients were included in the study. Demographic and clinical data of all ICU patients and according to the presence of a CMV or HSV reactivation are described in Table 1. Of these patients, 30 patients fulfilled the criteria of SIRS. Sepsis was documented in 4 patients. Nineteen patients suffered from a septic shock, whereas 7 patients experienced a severe sepsis.

No differences in length of stay in the ICU were found between patients with or without a CMV or HSV infection.

BAL was performed in 16 patients and ventilatory associated pneumonia was diagnosed in 9 patients. The isolated micro-organisms were Staphylococcus aureus, Enterobacteriaceae and Pseudomonas Aeruginosa.

\section{CMV and HSV IgG-antibodies}

Of the 60 patients, CMV IgG-antibodies were detected in 41 patients (67\%), while HSV IgG-antibodies were positive in $49(82 \%)$ patients. CMV IgG-antibodies and HSV IgG-antibodies were both present in 41 patients (67\%).

\section{CMV and HSV reactivation}

Reactivation of CMV or HSV according to the definition described above was found in respectively $19 \%(\mathrm{n}=8)$ and $28 \%(\mathrm{n}=14)$ of seropositive patients. Simultaneous reactivation of CMV and HSV was present in 4 patients. CMV reactivation occurred at an average of 15.7 days after admission, whereas a HSV was documented at an average of 8.0 days. No CMV or HSV seroconversion was documented, indicating that no primary infection for both CMV and HSV occurred in our patients. The number of positive results according to sample site and test result are given in Table 2 . In the 3 patients with a positive HSV culture of BAL fluid, no HSV was detected in salivary samples at that time. 
Table 2. Number of ICU patients with a CMV or HSV infection according to sample site and test result.

\begin{tabular}{lcccc}
\hline Sample site & Lung & Blood & Saliva & Urine \\
\hline Test & & & & \\
\hline Vc CMV & 3 & $\times$ & 0 & 0 \\
Vc HSV & & 2 & 11 & \\
IgG CMV & 5 & & \\
IgM CMV & 4 & & \\
IgG HSV & 5 & & \\
IgM HSV & 4 & $\times$ & $\times$ \\
CMV mRNA & 2 & $\times$ & \\
CMV DNA & 0 & & \\
HSV DNA & & & & \\
\hline
\end{tabular}

$V c=$ Viral culture; $x=$ not performed.

CMV or HSV reactivation, Sepsis, Mortality rate and Mechanical ventilation

CMV and HSV reactivation was present in respectively $23 \%(7 / 30)$ and $27 \%$ $(8 / 30)$ of septic patients. Of the 60 patients admitted to the ICU, 30 patients died, 5 patients died after discharge into the general ward. In patients with CMV reactivation the mortality rate tended to be higher than in patients without CMV reactivation. Five of the 8 patients (62\%) with CMV reactivation died, as opposed to 21 of the $41(51 \%) \mathrm{CMV}$ seropositive patients without reactivation $(P=0.06)$. Between patients with and without HSV reactivation no difference in mortality rate was found $(\mathrm{P}=0.6)$. CMV and HSV reactivation were associated with a prolonged requirement of mechanical ventilation (respectively, 23 days and 17 days) compared to those without reactivation (respectively 9 days and 7 days, $\mathrm{P}<0.05$ ).

\section{Discussion}

In this prospective study, that included sixty non-immune compromised patients admitted to a multidisciplinary ICU, CMV and HSV reactivations were found in $19 \%$ and $28 \%$ respectively of the seropositive patients. Patients that were expected 
to be ventilated for less than 7 days were excluded from the study due to the assumption that a critical illness that only lasts for some days may be an insufficient condition for these viruses to reactivate. It appeared indeed that HSV or CMV reactivation occurred after an average of 8 and 15 days respectively after ICU admission. This could be documented because all included patients were monitored as from admission on the ICU. The median duration of stay in the hospital prior to ICU admission was only 1 to 2 days, suggesting a recent onset of illness in the study population. Apart from this, nosocomial acquisition of these infections could not be demonstrated in CMV or HSV seronegative individuals.

In general, ICU patients are regarded as immunocompetent individuals. Nevertheless, depression of lymphocyte function, especially those of T-lymphocytes (28) has been described in surgical ICU patients, which make them more susceptible to reactivation of herpes viruses. Reactivation of herpes viruses, especially CMV, has been linked to increased levels of tumor necrosis factor-alpha (TNF- $\alpha$ ) (29), a common phenomenon in septic ICU patients (30). A recent prospective study by Heininger et al.(16) showed a high incidence of CMV reactivation in non-immune compromised CMV-seropositive critically ill ICU patients with a high simplified acute physiology score (SAPS II). In $35.6 \%$ of these patients, CMV DNA was detected in plasma, leukocytes, or tracheal secretions. In $12.5 \%$ of patients, the virus was cultured from the respiratory tract. Viremia did not occur. The presence of CMV-DNA was documented in up to $62,5 \%$ of septic patients. The study was performed in a highly selected group of critically ill patients and patients were enrolled after an average of 7 days on the ICU. Documentation of CMV infections did not include salivary and urinary cultures nor CMV-mRNA detection, as in our study. If positive this would strongly suggest CMV reactivation, while CMV-DNA testing, as performed in the study by Heininger et al. may theoretically also be detected during latency.

In our study, CMV reactivation was demonstrated in $23 \%$ when seropositive septic patients were considered. Our results support therefore the findings of others $(15,16)$ that CMV (re)infections are common among septic patients. Furthermore we documented an even more frequent reactivation of HSV. With the exception of one patient, reactivation of CMV occurred in all septic ICU patients. On the other hand the incidence of HSV reactivation in septic ICU patients equaled those without HSV reactivation $(57 \%(8 / 14)$ versus $63 \%(22 / 35))$. These findings are all in line with the findings in transplant recipients that HSV reactivation occurs earlier and in less immune compromised patients compared to CMV (31).

In the present study, apart from HSV cultures of oropharyngeal secretions and 
bronchoalveolar lavage fluids, the presence of HSV DNA in blood was studied as well. Unlike patients with recurrent herpes labialis (32) and patients with a clinical acute attack of multiple sclerosis (33), no HSV DNA could be detected in whole blood samples nor in separately isolated PBMCs. It seems therefore that in the ICU patients, HSV reactivation occurs from the usual sensory nerve ganglion sites and remains restricted to the oropharynx and by extension or aspiration to the respiratory tract but that HSV does not disseminate to visceral organs. The importance of HSV infection of the respiratory tract has been established in several reports, and is associated with prolonged requirement for mechanical ventilation, length of ICU stay and increased mortality (34-37). Also in the present study we found a prolonged requirement for mechanical ventilation in patients with $\mathrm{HSV}$ infection.

Our study showed that CMV reactivation occurs mostly in severely ill patients, especially those suffering from bacterial sepsis. The duration and severity of illness may have compromised the immune system in such a way that complete or partial CMV replication takes place. Apart from the infection of various cell types in different organs, CMV may also latently infect bone marrow progenitor cells. CMV reactivation may lead therefore to a systemic infection and in our patients the presence of viral DNA and mRNA in blood was also documented. However, no excretion of CMV in saliva or urine was found, a common phenomenon in transplant recipients with a systemic CMV infection (8). This means that in our study septic ICU patients were still able to eliminate the virus in a rapid manner or that no full viral replication occurred. As for HSV, CMV reactivation also appeared to be associated with a prolonged requirement for mechanical ventilation, however the cause and effect of this association could not be determined and the clinical relevance remains therefore disputable.

In summary, reactivation of CMV or HSV was documented in $19 \%$ and $28 \%$ respectively of the seropositive patients in our multidisciplinary ICU. Reactivation of CMV manifested itself 15 days after admission on the ICU by the detection of viral transcripts (mRNA and DNA) in blood mostly of septic patients while the excretion of complete virus in urine and saliva was not demonstrated. On the other hand HSV was cultured from saliva and airway secretions from both septic as well as non-septic patients 8 days after ICU admission. Both conditions resulted in prolonged requirements for mechanical ventilation although cause and effect remains unclear. 


\section{References}

1. Corely L, Spear PG. Infections with herpes simplex viruses. N Engl J Med 1986; 314:686691.

2. Ho M. Epidemiology of cytomegalovirus infections. Rev Infect Dis 1990; 12:S701-710.

3. Sweet C. The pathogenicity of cytomegalovirus. FEMS Microbiol Rev 1999; 23:457-482.

4. Rubin RH. Importance of CMV in transplant population. Transpl Infect Dis 1999; 1 Suppl 1: 3-7.

5. Nanicke D, Oldstone MB. Generalized immunosuppression: how viruses undermine the immune response. Cell Mol Life Sci 2000; 57:1399-1407.

6. Zanghellini F, Boppana SB, Emery VC, Griffits PD, Pass RF. Asymptomatic primary cytomegalovirus infection: Virologic and immunologic features. J Infect Dis 1999; 180: 702-707.

7. Cope AV, Sweny P, Sabin C, Rees L, Griffits PD, Emery VC. Quantity of cytomegalovirus viruria is a major risk factor for cytomegalovirus disease after renal transplantation. J Med Virol 1997; 52:200-205.

8. Lucht E, Brytting M, Bjerrgaard L, Julander I, Linde A. Sheddding of cytomegalovirus and herpesviruses 6,7 , and 8 in saliva of human immunodeficiency virus type 1 Infected patients and healthy controls. Clin Infect Dis 1998; 27:137-141.

9. Rabella N, Rodriquez P, Labeaga R, Otegui M, Mercader M, Gurgui M, Prats G. Conventional respiratory viruses recovered from immunocompromised patients: clinical considerations. Clin Infect Dis 1999; 28:1043-1048.

10. Klainer AS, Oud L, Randazzo J, Freiheiter J, Bisaccia E, Gerhard H. Herpes simplex virus involvement of the lower respiratory tract following surgery. Chest 1994; 106:8S$14 \mathrm{~S}$.

11. Gomez RS, Carneiro MA, Souza LN, Victoria JM, de Azevedo WM, De Marco L, Kalapothakis E. Oral recurrent human herpes virus infection and bone marrow transplantation survival. Oral Med Oral Pathol Radiol Endod 2001; 91:552-556.

12. Baras L, Farber CM, van Vooren JP, Parent D. Herpes simplex virus tracheitis in a patient with the acquired immunodeficiency syndrome. Eur Resp J 1994; 7: 2091-2093.

13. Knaup B, schunemann S, Wolff MH. Subclinical reactivation of herpes simplex virus in the oral cavity. Oral Microbiol Immunol 2000; 15: 281-283.

14. Augenbraun M, Corey L, Reichelderfer P, Wright DJ, Burns D, Koelle DM, Robison E, Cohen $\mathrm{M}$. Herpes simplex virus shedding and plasma human immunodeficiency virus RNA levels in coinfected women. Clin Infect Dis 2001; 33:885-890.

15. Kutza AST, Muhl E, Hackstein H, Kirchner H, Bein G. High incidence of active cytomegalovirus infection among septic patients. Clin Infect Dis 1998; 26:1076-1082.

16. Heininger A, Jahn G, Engel C, Notheisen T, Unertl K, Hamprecht K. Human cytomegalovirus infections in nonimmunosuppressed critically ill patients. Crit Care Med 2001; 29:541-547.

17. Cobben NA, Jacobs JA, van-Dieijen-Visser MP, et al. Diagnostic value of BAL fluid cellular profile and enzymes in infectious pulmonary disorders. Eur Respir J 1999; 14:496502. 
18. Knaus W.A, Draper E.A., Wagner D.P., Zimmerman J.E. APACHE II: a severity of disease classification system. Crit Care Med 1985: 13:818-829.

19. American college of Chest Physicians/society of Critical Care Medicine Consensus Conference: Definitions for sepsis and organ failure and guidelines for the use of innovative therapies in sepsis. Crit Care Med 1992; 20:864-874.

20. Blok MU, Goossens VJ, Vanherle SJ, Top B, Tacken N, Middeldorp JM, Christiaans MH, van Hooff JP, Bruggeman CA. Diagnostic value of monitoring human cytomegalovirus late pp67 mRNA expression in renal allograft recipients by nucleic acid sequence based amplification. J Clin Microbiol 1998; 36:1341-1346.

21. Gutiérrez J, Fernández F, Vergara MJ, Suárez S, Soto MJ, Maroto MC. Comparison of several ELISA tests for detecting the presence of $\lg$ and $\lg M$ against herpes simplex viruses. Micobios 2000; 103:127-132.

22. Kraat YJ, Christiaans MH, Nieman FH, van den Berg-Loonen PM, van Hooff JP, Bruggeman CA. Risk factors for cytomegalovirus infection and disease in renal transplant recipients: HLA-DR7 and triple therapy. Transpl Int 1994: 7:362-367.

23. Boom R, Sol CJA, Salimans MMM, Jansen CL. Wertheim-van Dillen PME, van der Noordaa J. Rapid and simple method for purification of nucleic acids. J Clin Microbiol 1990; 28:495-503.

24. Blok MJ, Christiaans MH, Goossens VJ, van Hooff JP, Sillekens P, Middeldorp JM, Bruggeman CA. Early detection of human cytomegalovirus infection after kidney transplantation by nucleic acid sequence based amplification. Transplantation 1999; 67: 1274-1277.

25. Chee MS., Bankier AT, Beck S, Bohni R, Brown CM, Cerny R, Horsnell T, Hutchison III CA, Kouzarides T, Martignetti JA, Preddie E, Satchwell SC, Tomlinson P, Weston KM and Barrell BG. Analysis of the protein-coding content of the sequence of human cytomegalovirus strain AD169. Curr Top Microbiol Immunol 1990; 154:125-169.

26. Hawrami K, Breuer J. Development of a fluorogenic polymerase chain reaction assay (TaqMan) for the detection and quantitation of varicella zoster virus. J Virol Methods 1999; 79: 33-40.

27. Ryncarz AJ, Goddard J, Wald A, Huang ML, Roizman B, Corey L. Development of a high-throughout quantitative assay for detecting herpes simplex virus DNA in clinical samples. J Clin Microbiol 1999; 37:1941-1947.

28. Sun X, lles M, Weissman C. Physiologic variables and fluid resusitation in the postoperative intensive care unit patient. Crit Care Med 1993; 21:555-561.

29. Döcke WD, Prösch S, Fietze E, Kimel V, Zuckermann H, Klug C, Syrbe U, Krüger DH, von Baehr R, Volk HD. Cytomegalovirus reactivation and tumour necrosis factor. Lancet 1994; 343:268-269.

30. Pinsky MR, Vincent JL, Deviere J, Alegre M, Kahn RJ, Dupont E. Serum cytokine levels in human septic shock. Relation to multiple system organ failure and mortality. Chest 1993; 103:565-575.

31. Deeg HJ, Bowden RA. Introduction to marrow and blood stem cell transplantation. Transplant infections. Edited by Bowden RA, Ljungman PL and Paya CV. LippincottRaven Publishers, Philadelphia 1998, Chapter 1. 
32. Brice SL, Stockert SS, Jester JD, Huff JC, Bunker JD, Weston WL. Detection of herpes simplex DNA in the peripheral blood during acute recurrent herpes labialis. J Am Acad Dermatol 1992; 26:594-598.

33. Ferrante P, Mancuso R, Pagani E, Guerini FR, Calvo MG, Saresella M, Speciale L, Caputo D. Molecular evidences for a role of HSV-1 in multiple sclerosis clinical acute attack. J Neurovirol 2000; 6 suppl 2: S109-S114.

34. Schuller D, Spessert C, Fraser VJ, Goodenberger DM. Herpes simplex virus from respiratory tract secretions: Epidemiology, clinical characteristics, and outcome in immunocompromised and nonimmunocompromised hosts. Am J Med 1993; 94:29-34.

35. Cushing D, Elliot S, Caplan E. Herpes simplex virus and cytomegalovirus excretion associated with increased ventilatory days in trauma patients. J trauma $1993 ; 35: 161$.

36. Tuxen DV. Prevention of lower respiratory herpes simplex infection with acyclovir in patients with adult respiratory distress syndrome. Chest 1994;106 (Suppl 1); S28-S33.

37. Cook CH, Yenchar JK, Kraner TO, Davies EA, Freguson RM. Occult herpes family viruses may increase mortality in critically ill surgical patients. Am J Surg 1998; 178: 357-360. 


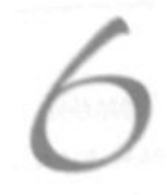

Summary 
The exact pathogenesis of ventilator-associated pneumonia (VAP) is still debated. In the past the gastropulmonary route of colonization of the respiratory tract was considered the most important. However, recently the theory of involvement of the oropharyngeal route has regained influence as an antecedent to VAP, and several studies have emphasized the pathogenic role for colonization in the oropharynx. Therefore a sound oropharyngeal mucosa, as an essential part of the host defense, is of the utmost importance. The oropharyngeal mucosa is a natural barrier in preventing adhesion and invasion of potentially pathogenic microorganisms (ppmo) like Enterobacteriaceae, Pseudomonas aeruginosa and Staphylococcus aureus. These microorganisms are considered the most important pathogens causing nosocomial pneumonia in ventilated intensive care patients, the so-called VAP.

Saliva plays an important role in maintaining the host defense of the oropharynx. It not only prevents damage by moistening the mucosa, but also it contains several specific antmicrobial substances like lysozyme, lactoferrine, peroxidase, fibronectin, cystatins and mucins which prevent adherence of ppmo. Absent or diminished salivary flow (xerostomia) can result in injury of the mucosa (mucositis), a substrate for ppmo adherence. Although it can be expected that saliva plays a key role in the host defense of the oropharynx in ICU patients, to our knowledge no research on salivary flow in ICU patients has been performed.

Also it is not known if changes in salivary flow or composition is linked with the occurrence of mucositis or ppmo colonization of the oropharynx in ICU patients. Therefore we performed a prospective study in ventilated ICU patients in which we studied the relation between salivary flow and mucositis of the oropharynx. We also studied when colonization of the oropharynx with ppmo occurred.

This study is described in chapter $\mathbf{1}$. The following parameters in time were determined: stimulated salivary flow (SSF), IgA output and degree of mucositis. At the same time semi-quantitative oropharyngeal cultures were taken.

Two types of ICU patients were studied and compared to each other. One group consisted of patients undergoing elective coronary artery by-pass (CABG) and was extubated within 24 hours. The other group consisted of patients from the multidisciplinary ICU who were admitted because of the need of mechanical ventilation for at least 48 hours. The results of this prospective study showed that the CABG patients experience a temporary decrease in SSF and IgA output, which did not result in mucositis, nor in acquired colonization of the oropharynx with ppmo.

A possible explanation is that these patients resume their oral intake, again permitting stimulation of saliva production. This results in lesser mucosal damage and dehydration. 
Totally different results were found in ventilated ICU patients. Soon after admission in the ICU absent SSF was documented and in the following weeks they developed an increase in mucositis. All ICU patients who had to be ventilated for more than 2-3 weeks showed signs of (severe) mucositis. Analysis of the oropharyngeal flora in time showed a significant increase of oropharyngeal colonization with ppmo, especially Enterobacteriaceae and Pseudomonas aeruginosa. At the same time a correlation was found between the acquired colonization with these types of microorganisms and presence of mucositis. In summary, it seems that ventilated ICU patients suffer from a nearly absent salivary flow, resulting in diminished protection and dehydration of the mucosa resulting in mucositis. Mucositis possibly attributes to colonization with ppmo, especially Enterobacteriaceae and Pseudomonas aeruginosa and subsequently will result in lower respiratory tract colonization.

Most of acquired infections in ventilated ICU patients result from respiratory tract infections. Therefore, most of antibiotics (50\%) prescribed in the ICU are for treating these infections. Excessive or inappropriate use of antibiotics can result in increasing antibiotic resistance, a nightmare for every clinician. One of the methods to reduce antibiotic use and resistance is to shorten the duration of antimicrobial therapy for respiratory tract infections in ventilated ICU patients. Although guidelines have been issued regarding this subject, they were never tested in a prospective randomized trial looking at resolution of infectious parameters. Little is known about the resolution of parameters like temperature, leukocyte count, gas exchange ( $\mathrm{PaO} 2 / \mathrm{FiO} 2$ ratio) and semi-quantitative cultures of tracheal aspirate after initiating antimicrobial therapy for VAP.

In chapter $\mathbf{2}$ the resolution of infectious parameters associated with VAP are studied after institution of appropriate antimicrobial therapy.

In this study VAP was diagnosed by means of bronchoalveolar lavage. All four parameters (temperature, leukocyte count, gas exchange ( $\mathrm{PaO} 2 / \mathrm{FiO} 2$ ratio) and semiquantitative cultures of tracheal aspirate) showed a significant improvement after the start of treatment of VAP, especially during the first 6 days. Enterobacteriaceae and $P$. aeruginosa were cultured from the tracheal aspirate during the treatment of VAP, despite adequate antimicrobial therapy and in vitro susceptibility. This was in contrast to pathogens like Hemophilus influenzae, Streptococcus pneumoniae and Staphylococcus aureus; these pathogens disappeared quickly from the tracheal aspirate. From the sixth day on after initiating antimicrobial ther- 
apy in these patients, in essence Enterobacteriaceae and $P$. aeruginosa were cultured from the tracheal aspirate. Our results raises the question if the advised duration of 14-21 days for treatment of VAP is too long, because after 6 days of antibiotic therapy infectious parameters have normalized. In some of the patients a shortening of the duration of antimicrobial therapy could even have prevented new acquired colonization with Enterobacteriaceae and P. aeruginosa.

Like in ventilated ICU patients, also cystic fibrosis (CF) patients experience persistent $P$. aeruginosa colonization of tracheal secretions despite adequate antimicrobial therapy. The persistence of $P$. aeruginos $a$ in $C F$ patients among others has been attributed to changes in mucin composition of tracheal secretions. Especially the increase in sulfation and sialylation of mucin is held responsible. Recently a mucin-sulfatase has been demonstrated in $P$. aeruginosa, an enzyme capable of breaking down mucins, which enable $P$. aeruginosa to survive in the mucus. Chapter 3 addresses the question if increased levels of sulfated mucins are found in the lower airways of patients with VAP. To test this hypothesis BAL samples were prospectively examined in ventilated ICU patients with VAP. These patients were compared with ventilated ICU patients and non-ventilated outpatients without a respiratory infection.

The levels of sulfated mucins in BAL samples in our study appeared to be 3-5 times higher in ventilated ICU patients with VAP than in patients without a respiratory infection. Mechanical ventilation did not influence the level of sulfated mucin. No significant differences in the level of sulfated mucin were found between the different pathogens causing VAP. Therefore it seems that the increase in sulfated mucins is the result of inflammation due to the infection, as was recently demonstrated in cystic fibrosis (CF).

The results as described in chapter 1 show that a decrease in salivary flow in ventilated ICU patients can result in damage to the oropharyngeal mucosa. The increase in oropharyngeal mucosal injury paralleled the degree of ppmo colonization. This points towards a deterioration of the normal barrier function (non-specific immunity) of the oropharyngeal mucosa in ICU patients. Also severely ill patients show a deterioration of their cellular immunity. This is why herpesviruses like cytomegalovirus (CMV) and herpes simplex virus (HSV), which reside in a latent form in the host after primary infection, can reactivate. If reactivation occurs it can result in mucosal in jury of the oropharynx and respiratory tract. HSV can cause severe gingivostomatitis, or tracheobronchitis. CMV can cause xerostomia and 
even pneumonia. Also these herpesviruses have been linked to the occurrence of oropharyngeal ppmo colonization. Data about the nature and magnitude of herpes reactivation in ICU patients are somewhat conflicting. To gain understanding of the importance of herpes reactivation we performed two prospective studies. We studied two types of ICU patients. ICU patients who are exposed to stress of short duration, i.e. patients undergoing elective CABG and ICU patients with persistent stress, i.e. patients in need of mechanical ventilation with an expected duration of ICU admission of at least one week.

In chapter 4 patients undergoing elective $C A B G$ were examined for the presence of CMV reactivation. For this purpose blood, urine and saliva samples were tested, before and one and two weeks after the operation. Besides the use of a conventional viral culture technique, serological antibody detection (IgG and IgM) and the monoclonal antibodies directed again CMV, samples were tested with more sensitive techniques like Nucleic Acid Sequence-Base Amplification (NASBA) and polymerase chain reaction (PCR). The latter two are able to detect CMV-mRNA and -DNA. Also serological investigation was performed 2-3 months after the operation. None of the CMV seropositive patients showed a significant rise in serological antibodies, in the 2-3 months after the operation. In saliva and urine no CMV could be detected by means of conventional cultures or PCR. Peripheral blood mononuclear cells (PBMCs) were isolated from blood samples and tested for the presence of CMV with the aid of monoclonal antibodies and PCR. Blood samples were also tested by means of NASBA and PCR. In both PBMCs of CMV seropositive patients and $\mathrm{CMV}$ seronegative patients monoclonal antibodies against CMV were detected. This could not be confirmed by PCR. Also no CMVmRNA and -DNA was present in these blood samples.

Chapter 5 deals with the results of our study on the presence of CMV and HSV reactivation in ICU patients. The same technique to detect CMV was used as mentioned in chapter 4 . For the detection of HSV a conventional viral culture technique, serological testing and PCR was used. Again blood, urine and saliva samples were tested. If a BAL was performed in these patients because of the suspicion of a VAP these samples were also tested for the presence of CMV and HSV by means of a conventional culture viral technique. Reactivation of CMV and HSV was demonstrated in $19 \%(n=8)$ and respectively $28 \%(n=14)$ of seropositive patients. Primarily septic patients were at risk of developing viral reactivation. Twenty-three percent of septic patients showed CMV reactivation, while in $27 \%$ 
HSV reactivation was documented. CMV reactivation was detected at an average of 15 days after admission to the ICU by detection of mRNA and DNA in blood samples, while the virus could not be detected in urine or saliva.

On the other hand HSV was cultured from saliva and airway secretions from both septic as well as non-septic patients at an average of 8 days after ICU admission. Both CMV and HSV reactivation were associated with a prolonged requirement of mechanical ventilation (respectively 23 days and 17 days) compared to those without reactivation (respectively 9 days and 7 days). No primary herpes infection was found by means of serological investigation.

This thesis consists of some important observations. First of all the conclusion of chapter 1 was that deterioration of the oral mucosa is a common phenomenon in ventilated ICU patients, which resulted in a profound mucositis and concomitant increase in oropharyngeal colonization with ppmo. This in itself is a risk factor for the development of VAP due to aspiration of these ppmo. The question is can the deterioration of the oral mucosa be prevented? Normally oral care is consigned to ICU nurses who rightly prioritize their care to immediate medical problems. Also ICU nurses have not been formally trained to assess the oral status of patients in the intensive care units, and often no oral care protocol for these patients is available. Despite this imperfection, ICU nurses play an important role in preventing deterioration of the oral mucosa in ICU patients. If properly trained and supported by dental hygienists, it has been shown that ICU nurses were able to reduce oral mucositis of patients in the ICU by means of the implementation of a well-developed oral care protocol. If this will reduce the extent of oropharyngeal colonization with ppmo is the subject of further studies. From chapter 2 it can be concluded that resolution of infectious parameters in VAP, if adequately treated, mostly occurs within 6 days after the start of antibiotic therapy. Despite adequate antibiotic therapy these patients have persistent or acquired tracheal colonization with Gram-negative bacteria (GNB). The latter occurs in most patients after 6 days of treatment. One of the explanations is that these patients acquire GNB colonization due to selective antibiotic pressure. Therefore, we propose to perform a prospective randomized trial to evaluate the effect of a shorter duration of antibiotic therapy for VAP, i.e. 7 days instead of 14-21 days on acquired GNB tracheal colonization. Also such a study could help to reduce the risk of adverse drug events and help to cut health care costs. In chapter 3 we found an increase in sulfated mucins in BALF of patients with VAP, like in tracheal secretions of CF patients. The increase of sulfated mucins was probably due to inflammation. Furthermore, the in- 
crease of sulfated mucins might contribute to a decreased clearance of pathogens from the lower airways in ventilated ICU patients. Therefore it would be interesting to study the evolvement of the sulfated mucin in tracheal secretions from the start of mechanical ventilation. And to see if the increase of sulfated mucins parallels the increase in microbial colonization of tracheal secretions. Chapter 4 questions the use of immunocytology, as described by other investigators, for the detection of CMV reactivation. We feel this technique is to aspecific, because NASBA or PCR could not confirm CMV reactivation, not even by a rise in CMV antibodies. Our study showed that examination of blood samples by means of monoclonal antibodies directed again CMV is liable to erroneous observations. Recent studies on this subject, using this technique should therefore be interpreted with caution. Herpes viral reactivation is a common phenomenon in immune-compromised patients, like in transplant recipients and those with aids. In general the possibility of HSV or CMV reactivation receives little attention in critically ill patients who are admitted to the ICU, because they are considered immune-competent. The study, as addressed in chapter 5 , on HSV and CMV reactivation in our multidisciplinary ICU confirms the reactivation of these viruses, as was described by other investigators. Especially septic patients were at risk of developing viral reactivation. The question whether CMV and HSV reactivation contribute to an increase of mortality in critically ill patients has to be answered in future studies. 


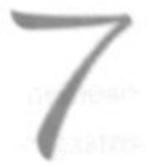

Samenvatting 
Er bestaan verschillende theorieën met betrekking tot de pathogenese van de nosocomiale pneumonie bij een mechanische beademde patiënt. Alhoewel de gastropulmonale route van kolonisatie van de lagere luchtwegen door sommige als belangrijkste wordt beschouwd, heeft het belang van de oropharyngeale route de laatste jaren aan terrein gewonnen. Dit concept benadrukt het belang van intacte oropharyngeale slijmvliezen als essentieel onderdeel van de aspecifieke lokale afweer. De oropharyngeale slijmvliezen vormen een natuurlijke en eerste mechanische barrière en voorkomen aanhechting en invasie van potentieel pathogene micro-organismen (ppmo) zoals Enterobacteriaceae, Pseudomonas aeruginosa en Staphylococcus aureus. Deze micro-organismen worden beschouwd als de belangrijkste verwekkers van de nosocomiale pneumonie bij mechanische beademde patiënten, ook wel 'ventilator-associated pneumonia' of VAP genoemd.

Speeksel speelt een belangrijke rol bij zowel de specifieke als niet specifieke afweer van de oropharynx. Het voorkomt niet alleen beschadiging van de slijmvliezen door bevochtiging maar ook door meer specifieke al dan niet antimicrobièle bestanddelen, zoals o.a. lysozyme, lactoferrine, peroxidase, fibronectine, cystatinen en mucinen wordt aanhechting van ppmo voorkomen. Een afgenomen of afwezige speeksel productie (xerostomia) kan leiden tot oropharyngeale slijmvlies beschadiging (mucositis), waardoor ppmo zich aan het slijmvlies kunnen hechten. Alhoewel men van de veronderstelling mag uitgaan dat speeksel een belangrijke rol speelt bij de lokale afweer van de oropharynx bij type intensive care (IC) patiënten, is tot op heden nooit onderzocht hoeveel speeksel er wordt geproduceerd bij IC patiënten tijdens hun opname op de intensive care. Tevens is niet bekend of een veranderde speekselproductie of samenstelling verband houdt met het optreden van mucositis en/of aanleiding geeft tot kolonisatie met ppmo van de oropharynx bij IC patiënten.

Hoofdstuk 1 beschrijft de resultaten van een prospectieve studie beschreven waarin onderzocht werd of er bij beademde IC patiënten een verband bestond tussen de productie en de kwaliteit van het speeksel en oropharyngeale mucocitis. Ook werd bestudeerd wanneer kolonisatie met ppmo optrad. De volgende parameters werden in de loop van de tijd gemeten: gestimuleerde speeksel flow (SSF), IgA speeksel afgifte, ernst van de mucositis. Op dezelfde tijdstippen werden semikwantitatieve oropharyngeale kweken afgenomen. Twee type IC patiënten werden bestudeerd en ook met elkaar vergeleken. Eén groep bestond uit patiënten die een electieve coronaire-bypass operatie (CABG) ondergingen en binnen 24 uur gedetubeerd werden. De andere groep bestond uit algemene IC patiënten die minimaal 48 
uur beademingsbehoeftig waren. De resultaten van dit prospectief onderzoek laten zien dat er bij CABG patiënten een kortdurende daling van de SSF en IgA speeksel afgifte optreedt hetgeen niet resulteerde in mucositis noch in verworven kolonisatie met ppmo. Een mogelijke verklaring hiervoor is dat deze patiënten reeds de tweede dag postoperatief hun orale intake hervatten, waardoor de speeksel productie wordt gestimuleerd, en schade aan de slijmvliezen door onder andere uitdroging wordt voorkomen. Totaal andere resultaten worden gevonden bij de IC patiënten. Reeds kort na opname op de IC is er sprake van een afwezige SSF, en in de weken na het starten van de beademing wordt een significante toename van de mucositis waargenomen. Bij alle IC patiënten die langer dan 2-3 weken beademd moesten worden was er sprake van (ernstige) mucositis. Analyse van de orophayngeale flora vertoonde een significante toename in de kolonisatie met ppmo, met name die van Enterobacteriaceae en Pseudomonas Aeruginosa. Tevens bleek er een correlatie te bestaan tussen het verwerven van deze kolonisatie met deze typen micro-organismen en de aanwezigheid van mucositis. Samenvattend lijkt het erop dat bij beademde IC patiënten de speeksel productie sterk afneemt hetgeen tot gevolg heeft dat slijmvliezen uitdrogen en onder andere daardoor mucositis kan ontstaan. De mucositis draagt mogelijk bij aan de kolonisatie met Gram-negatieve micro-organismen in de oropharynx en als gevolg daarvan van de lagere luchtwegen. Toekomstig onderzoek gericht op het voorkomen van mucositis, zal moeten uitwijzen of dit vermoeden bevestigd zal worden.

Het merendeel van de op de IC verworven infecties treden op bij beademde patiënten, hierbij gaat het met name om luchtweginfecties. Dit houdt tegelijkertijd in dat het grootste deel $( \pm 50 \%$ ) van het antibiotica gebruik op het conto komt van deze luchtweginfecties. Overmatig gebruik van antibiotica leidt tot selectie van multiresistente micro-organismen met alle gevolgen van dien. Een van de manieren om het antibioticum gebruik en resistentie terug te dringen is de therapie duur voor deze luchtweginfecties te verkorten. Alhoewel er richtlijnen bestaan met betrekking tot de therapie duur voor deze luchtweginfecties, zijn deze nooit getoetst in een prospectieve studie waarbij gekeken werd naar een verbetering van infectieuze parameters. Er is dan ook weinig bekend over de respons van parameters zoals temperatuur, leukocyten getal, gaswisseling ( $\mathrm{PaO} 2 / \mathrm{FiO} 2$ ratio) en semi-kwantitatieve kweken van trachea aspiraat op antimicrobiële therapie voorgeschreven in het kader van VAP. In hoofdstuk $\mathbf{2}$ wordt de respons van deze parameters beschreven na het starten van antimicrobiële therapie.

VAP werd bij alle patiënten vastgesteld door middel van een broncho-alveolaire 
lavage. Alle vier parameters lieten een significante verbetering zien na het starten van de behandeling en met name gedurende de eerste 6 dagen. Enterobacteriaceae en $P$. aeruginosa werden gedurende de hele therapie voor VAP uit het trachea-aspiraat gekweekt, ondanks adequate therapie en met blijvende in vitro gevoeligheid. Dit in tegenstelling tot verwekkers zoals $H$. influenzae, $S$. pneumoniae en $S$. aureus ; deze bacteriën verdwenen snel uit het trachea aspiraat, en vanaf de 6de dag na het starten van de antimicrobiële behandeling werd bij deze patiënten voornamelijk Enterobacteriaceae en $P$. aeruginosa uit het trachea aspiraat gekweekt. Deze gegevens suggereren dat de geadviseerde therapie duur van 14-21 dagen voor VAP te lang is, omdat na 6 dagen antibiotica de infectieuze parameters zijn genormaliseerd. Bij sommige patiënten zou door een kortere behandeling mogelijk zelfs een nieuwe kolonisatie met Enterobacteriaceae en $P$. aeruginosa kunnen worden voorkomen. Uiteraard dient deze hypothese getest te worden in een goed uitgevoerde studie.

Net als bij beademde IC patiënten, is er ook bij cystic fibrose patiënten sprake van persisterende $P$. aeruginosa kolonisatie van het sputum ondanks vaak adequate antibiotische therapie. Het persisteren van $P$. aeruginosa wordt bij deze CF patiènten o.a. toegeschreven aan een verandering van de mucine samenstelling van het sputum. Een toegenomen sulfatering en sialysering van deze mucines is hier mede voor verantwoordelijk. Recent is aangetoond dat $P$. aeruginosa beschikt over een mucine-sulfatase, een enzym dat gesulfateerde mucines afbreekt, die het hem mogelijk maakt in de mucus te overleven. Hoofdstuk 3 gaat in op de vraag of er ook bij VAP een verhoogde concentratie van gesulfateerde mucines aanwezig is in de diepere luchtwegen. Om deze hypothese te testen werd prospectief de broncho-alveolaire lavage (BAL) vloeistof onderzocht van beademende IC patiënten met een VAP. De beademde IC patiënten met VAP werden vergeleken met beademde IC patiënten en niet-beademde poliklinische patiënten zonder een luchtweginfectie.

De concentratie van gesulfateerde mucines bij beademde patiënten met een VAP bleek 3-5x zo hoog als bij de patiënten zonder een luchtweginfectie. De mechanische beademing had geen invloed op de concentratie van gesulfateerde mucines. Er bestonden geen significante verschillen in de concentraties van gesulfateerde mucines tussen de verschillende typen verwekkers van VAP. De verhoogde concentratie van gesulfateerde mucines lijkt een gevolg van de ontsteking veroorzaakt door de infectie, zoals recent ook is aangetoond in CF. 
De in hoofdstuk 1 beschreven resultaten laten zien dat afname van de speekselproductie bij beademde IC patiënten slijmvlies beschadiging van de oropharynx in de hand werkt. Parallel aan de toename in ernst van slijmvlies schade werd ppmo kolonisatie waargenomen. Dit wijst op duidelijke achteruitgang in mechanische barrière functie (niet-specifieke immuniteit) van de slijmvliezen van de oropharynx. Daarnaast is uit eerder onderzoek gebleken dat ernstig zieke patiënten tevens een achteruitgang laten zien van de cellulaire immuniteit. Hierdoor kunnen herpesvirussen zoals cytomegalovirus (CMV) en herpes simplex virus (HSV), die latent in het lichaam aanwezig zijn na een eerder doorgemaakte infectie, weer reactiveren. Wanneer hiervan sprake is kan dit leiden tot een beschadiging van de slijmvliezen van zowel de hogere als de lagere luchtwegen. In het geval van HSV kan dit een ernstige gingivo-stomatitis, en of tracheobronchitis veroorzaken. CMV kan xerostomie en zelfs een virale pneumonie veroorzaken. Deze herpesvirus infecties zijn ook in verband gebracht met kolonisatie van de oropharynx door ppmo's.

De gegevens t.a.v. aard en omvang van herpes reactivatie bij IC patiënten zijn tegenstrijdig. Om een beter inzicht te krijgen in het belang van herpes virus reactivatie werden twee prospectieve studies verricht. Twee typen IC patiënten werden bestudeerd. IC patiënten die blootstaan aan kortdurende stress zoals patiënten die een electieve coronary-bypass operatie (CABG) ondergaan. Daarnaast werden IC patiënten met aanhoudende stress bestudeerd, d.w.z. IC patiënten die werden opgenomen op de algemene intensive care met een indicatie voor mechanisch beademing en een verwachte verblijfsduur van minimaal één week.

In hoofdstuk 4 worden patiënten die in aanmerking komen voor een electieve coronary-bypass operatie $(\mathrm{CABG})$ prospectief onderzocht op de aanwezigheid van CMV reactivatie. Hiervoor werden bloed, speeksel en urine monsters onderzocht. Zowel preoperatief als één en twee weken postoperatief. Naast het gebruik van conventionele viruskweken, serologisch onderzoek en monoclonale antistoffen gericht tegen CMV (MoAb-anti CMV) werd gebruik gemaakt van gevoelige technieken zoals Nucleic Acid Sequence-Based Amplification (NASBA) en de polymerase chain reactie (PCR). Deze laatste twee zijn in staat om CMV-mRNA en -DNA aan te tonen. Serologisch onderzoek werd nogmaals 2-3 maanden na de operatie herhaald. Bij geen van de CMV seropositieve patiënten werd een titer stijging in het bloed waargenomen, ook niet na 2-3 maanden. In het speeksel en de urine werd d.m.v. conventionele kweken, alsook met PCR geen CMV aangetroffen. Perifere mononucleaire cellen (PBMCs) uit volbloed werden separaat geïsoleerd en onderzocht op de aanwezigheid van CMV m.b.v. monoclonale antistoffen en PCR. 
Volbloed werd op de aanwezigheid van CMV getest met behulp van NASBA en PCR.

Zowel in PBMCs van CMV seropositieve alsook seronegatieve patiënten werd met behulp van monoclonale antilichamen CMV waargenomen. Dit kon echter niet bevestigd worden door PCR. Ook in volbloed werden geen aanwijzingen gevonden voor de aanwezigheid van CMV-mRNA en/of DNA. Hetgeen suggereert dat het waargenomen effect in de antigeen detectietest aspecifiek van aard is.

In Hoofdstuk 5 worden de resultaten van het onderzoek naar de aanwezigheid van CMV en/of HSV reactivatie bij IC patiënten beschreven. Dezelfde technieken, zoals aangegeven in hoofdstuk 4 werden gebruikt om CMV reactivatie aan te tonen. Voor het aantonen van HSV reactivatie werd gebruik gemaakt van conventionele viruskweken, serologisch onderzoek en PCR. Bloed, urine en speeksel werden hiervoor onderzocht. Indien bij deze patiënten een bronchoalveolaire lavage (BAL) plaatsvond i.v.m de verdenking VAP werd de BAL vloeistof tevens onderzocht op de aanwezigheid van CMV en HSV met behulp van conventionele viruskweken.

Reactivatie van CMV of HSV werd aangetoond bij 19\% $(n-8)$ respectievelijk $28 \%(n=14)$ van de seropositieve patiënten. Voornamelijk septische patiènten hadden risico on vinıs reactivatie. het hleek dat $22 \%$ van dese,natiënten tokenen hadden van een CMV reactivatie terwijl $27 \%$ een $\mathrm{HSV}$ reactivatie ondervond. CMV reactivatie werd gedetecteerd na 15 dagen opname op de IC door de detectie van mRNA en DNA in het bloed, terwijl de excretie van compleet virus in urine en speeksel niet kon worden aangetoond. HSV werd gekweekt in speeksel en trachea aspiraat 8 dagen na opname op de IC. Zowel bij patiënten met een reactivatie van CMV als HSV werd significant langere beademingsduur gevonden, vergeleken met de patiënten zonder tekenen van reactivatie. CMV en HSV reactivatie gingen gepaard met een langere beademingsduur (respectievelijk 23 versus 17 dagen) vergeleken met patiënten zonder reactivatie (respectievelijk 9 versus 7 dagen. Serologisch waren er geen aanwijzingen voor een nieuwe CMV of HSV infectie.

Dit proefschrift bevat een aantal belangrijke bevindingen. Ten eerste wordt in hoofdstuk 1 geconcludeerd dat achteruitgang van de slijmvliezen van de mond een veel voorkomend probleem is bij beademde IC patiënten. Dit resulteerde in ernstige mucositis en tegelijkertijd een toename van oropharyngeale kolonisatie met ppmo. Hetgeen op zichzelf een risicofactor is voor de ontwikkeling van een VAP door microaspiratie. De vraag is of achteruitgang van de slijmvliezen voorkomen 
kan worden? Op de IC wordt de mondverzorging toevertrouwd aan IC verpleegkundigen die terecht hun aandacht richten op problemen die de vitale functies bedreigen. Bovendien worden IC verpleegkundigen niet systematisch geschoold in het vaststellen van slijmvlies veranderingen bij IC patiënten. Bovendien zijn er vaak geen richtlijnen voor de mondverzorging van deze patiënten aanwezig. Ondanks deze tekortkomingen spelen IC verpleegkundigen een belangrijke rol in het voorkomen van de achteruitgang van de slijmvliezen.

Onderzoek heeft aangetoond dat wanneer IC verpleegkundigen voldoende worden getraind en worden bijgestaan door een mondhygiëniste zij in staat zijn de mucositis terug te dringen indien daarbij gebruik gemaakt wordt van een goed mondverzorgingsprotocol. Of dit ook de mate van kolonisatie door ppmo doet afnemen zal verder bestudeerd moeten worden. De conclusie uit hoofdstuk 2 is dat infectieuze parameters tijdens adequate antimicrobiële therapie van VAP met name verbeteren gedurende eerste 6 dagen na het starten van de behandeling. Ondanks adequate antimicrobiële therapie is er bij deze patiënten sprake van blijvende of nieuwe oropharyngeale kolonisatie met gramnegatieve bacteriën (GNB). Dit laatste werd vanaf de zesde dag na het starten van de antimicrobiële therapie waargenomen. De nieuwe kolonisatie van GNB wordt o.a. veroorzaakt door selectie druk door de gebruikte antibiotica. We stellen daarom ook voor een gerandomiseerde studie te verrichten naar het effect van een kortere behandelingsduur van VAP, d.w.z. 7 dagen i.p.v. 14-21 dagen op de nieuwe GNB kolonisatie van het trachea secreet. Ook kan een dergelijke studie bijdragen aan een afname van het aantal bijwerkingen door antibiotica en kosten door antibiotica gebruik. In hoofdstuk 3 werd een toename van het gesulfateerde mucine gehalte in bronchoalveolaire lavage vloeistof waargenomen bij patiënten met een VAP, zoals dit ook het geval is in trachea secreet van patiënten met de taai slijm ziekte. De toename van de gesulfateerde mucines berust waarschijnlijk op de ontsteking door de infectie. Bovendien kan deze toename bijdragen aan een verminderde klaring van pathogene micro-organismen uit de diepere luchtwegen bij beademde IC patiënten. Gezien deze bevindingen is het interessant een studie te verrichten naar het beloop van de gesulfateerde mucines in het tracheasecreet van IC patiënten vanaf de start van de beademing. En of een toename van de hoeveelheid gesulfateerde mucines parallel loopt met een toename van de bacteriële kolonisatie van trachea secreet.

Hoofdstuk 4 stelt het gebruik van immunocytology, de zogenaamde antigeen detectietest, voor het aantonen van CMV reactivatie, zoals beschreven is door andere onderzoekers, ter discussie. Uit ons onderzoek komt naar voren dat deze techniek 
te aspecifiek is voor het aantonen van CMV reactivatie, met name omdat de door deze techniek aangetoonde CMV reactivatie niet bevestigd kon worden door gebruik te maken van zeer gevoelige technieken zoals NASBA of PCR. Ook werd geen stijging van de antistof titer van CMV waargenomen. Onze studie heeft laten zien dat het onderzoek met monoklonale antilichamen gericht tegen CMV fout positief kan zijn en met grote voorzichtigheid moet worden geïnterpreteerd. Recente studies m.b.t. dit onderwerp moeten daarom met de nodige voorzichtigheid worden geïnterpreteerd.

Reactivatie van herpes virussen een veel voorkomend verschijnsel is bij im. muungecompromiteerde patiënten, zoals niertransplantatie patiënten en patiënten met AIDS. De mogelijkheid van een HSV of CMV reactivatie bij ernstig zieke intensive care patiënten wordt echter zelden overwogen, omdat zij als immunocompetent worden beschouwd. De studie, zoals beschreven in hoofdstuk 5, naar HSV en CMV reactivatie in onze multidisciplinaire IC toont aan dat reactivatie van zowel CMV als HSV optreed bij IC patiënten. Met name bij septische intensive care patiënten werd CMV reactivatie frequent waargenomen. De vraag is of CMV en HSV reactivatie bijdragen aan de mortaliteit van ernstig zieke IC patiènten. Dit zal beantwoord moeten worden door toekomstige studies. 


\section{List of abbreviations}

$\begin{array}{ll}\text { BAL } & \text { Bronchoalveolar lavage } \\ \text { BALF } & \text { Bronchoalveolar lavage fluid } \\ \text { CABG } & \text { Coronary bypass grafting } \\ \text { CF } & \text { Cystic fibrosis } \\ \text { CFU } & \text { Colony-forming units } \\ \text { CMV } & \text { Cytomegalovirus } \\ \text { CPITN } & \text { Community Periodontal Index of Treatment Needs } \\ \text { HSV } & \text { Herpes simplex } \\ \text { PBMCs } & \text { Peripheral blood mononuclear cells } \\ \text { PPMO } & \text { Potentially pathogenic micro-organisms } \\ \text { SSF } & \text { Stimulated salivary flow } \\ \text { VAP } & \text { Ventilator-associated pneumonia }\end{array}$




\section{Dankwoord}

De eerste steen voor dit proefschrift is gelegd vlak voor de afronding van mijn opleiding tot internist. Door de inbreng van Marc Bonten, met steun van professor Hillen en professor Ramsay, kreeg ik de gelegenheid wetenschappelijk onderzoek te verrichten op een terrein binnen de interne geneeskunde wat mij altijd al aansprak, de intensive care geneeskunde. Hiervoor ben ik hen nog altijd zeer dank. baar. Het was Marc die mij begeleide tijdens mijn eerste onwennige kennismaking met het wetenschappelijk onderzoek. De samenwerking was vruchtbaar, in korte tijd werden drie artikelen gepubliceerd, waarvan de belangrijkste is opgenomen in dit proefschrift.

Ook was er tijd voor ontspanning. Onvergetelijke momenten waren de weekendjes Gent met Marc Bonten, Jan van de Brande en Pieter van Paassen. Bedankt jongens. Door het vertrek van Marc naar Utrecht kwam e.e.a. op losse schroeven te staan en leek afronding van het proefschrift verder weg dan ooit.

Maar toen kwam André van der Ven. Hij nam met verve de coaching over. Door zijn inbreng werden diverse hordes genomen, bakens verzet en nog voor ik het in de gaten had stond het proefschrift weer in de steigers. Zijn daadkracht, optimisme en vastberadenheid werkten besmettelijk en zorgden ervoor dat ik nooit mijn doel uit het oog verloor. Altijd had hij een luisterend oor als het eens tegenzat. In zijn kleine kamertje, waar ik gebruik van mocht maken, werd intensief gediscussieerd. Niet alleen over de voortgang en inhoud van het onderzoek, maar ook over zaken die ons beiden bezig hielden. Beste André, bij deze mijn zeer grote dank.

De verandering van coach bracht met zich mee dat een "virale poot" in het onderzoek werd geïntegreerd. Professor Cathrien Bruggeman wil ik bedanken omdat zij zonder te aarzelen hiervoor haar laboratorium en knowhow ter beschikking stelde. Het was Gert Grauls die mij wegwijs maakte op het research laboratorium en mij met raad en daad bijstond. Samen hebben wij er met heel veel plezier een heel glasservies doorheen gedraaid. Ook Rien Blok wil ik bedanken, hij was altijd bereid mijn manuscripten van het nodige commentaar te voorzien. Bovendien niet te vergeten Martine Hulsbosch en Monique Coomans, die respectievelijk de CMVPCR en de bacteriologische kweken voor hun rekening namen. Jan Jacobs bedankt voor het beschikbaar stellen van de broncho-alveolaire samples. Ook alle andere medewerkers van het laboratorium Medische Microbiologie die ook maar op eniger- 
lei wijze aan het onderzoek hebben bijgedragen wil ik langs deze weg bedanken. Jos Maessen en Paul Roekaerts wil ik ook bedanken, zij maakten het onderzoek op de afdeling cardio-pulmonale chirurgie mogelijk.

Hubert Niesters uit het Dijkzigt ziekenhuis te Rotterdam, bedankt voor het verrichten van de HSV-PCR.

Kort na mijn kennismaking met André werd tevens contact gelegd met Enno Veerman en professor Arie van Nieuw Amerongen van de afdeling Orale Biochemie van de Vrije Universiteit. Al snel leidde dit tot een enthousiaste en constructieve samenwerking, waardoor het belang van speeksel en mucine als onderdeel van de lokale afweer zijn weerslag kregen in dit proefschrift. Beiden wil ik hiervoor hartelijk bedanken.

In dit kader moeten ook de mondhygiënistes Mariel Vlasveld, Linka Lokker en Sylvia Lieben genoemd worden. Zij waren ten alle tijde bereid om naast hun drukke werkzaamheden intensive care patiënten te onderzoeken op de aanwezigheid van mucositis. $\mathrm{l}$ wil hen dan ook bedanken voor de prettige samenwerking en inzet.

Fons Kessels bedankt voor je statistische bijdrage, dankzij jou heb ik er iets van leren begrijpen.

Karin Schröder bedankt voor de plastische weergave van bacterieën en virussen op de omslag. Zij zijn nu eindelijk met het blote oog van elkaar te onderscheiden.

Uiteraard ben ik ook veel dank verschuldigd aan alle patiënten en directe familie die hun medewerking hebben verleend om dit onderzoek mogelijk te maken. Tot slot zal duidelijk zijn dat dit onderzoek niet mogelijk was zonder de medewerking van de verpleegkundigen en coördinatoren van de afdelingen D3, E3, F3, D5 en C5. Zij waren altijd uitermate behulpzaam bij het afnemen van bloedmonsters en kweken. Hartelijk dank.

En nu lieve Carla en my $\mathbf{4}$ fabulous girls, op naar het strand. 


\section{Curriculum Vitae}

De auteur van het proefschrift werd geboren op 10 juli 1960 te Nijmegen. Na het behalen van het Atheneum-B diploma (Stedelijke Scholengemeenschap te Nijmegen) ging hij studeren aan de Katholieke Universiteit te Nijmegen. Het eerste jaar Biologie als parkeerstudie, vervolgens Geneeskunde. In 1988 behaalde hij zijn artsdiploma. Na de vervulling van zijn militair dienstplicht als kazerne-arts te Schaarsbergen, werkte hij als arts-assistent interne geneeskunde in het Gemeente Ziekenhuis (thans Rijnstate Ziekenhuis) te Arnhem (opleider Dr. J.M. Werre). Zijn opleiding tot internist nam een aanvang in 1992 in het de Weverziekenhuis (thans Atrium Medisch Centrum) te Heerlen (opleider Dr. F.A.Th. Lustermans), en werd afgerond in april 1998 in het Academisch Ziekenhuis Maastricht (opleider Prof. dr. H.F.P. Hillen). Kort daarop volgde, in hetzelfde ziekenhuis, de opleiding tot intensivist (opleider Prof.dr. G. Ramsay) en werd tevens aan de totstandkoming van dit proefschrift gewerkt. Vanaf april 2000 is hij werkzaam als internist-intensivist in het Medisch Centrum Haaglanden, lokatie Westeinde te Den Haag.

Hij is getrouwd met Carla Blenke en heeft vier dochters, Josefien, Lisanne, Marie-Sophie en Frederique. 
